UNIVERSIDADE DE SÃO PAULO

FACULDADE DE FILOSOFIA, LETRAS E CIÊNCIAS HUMANAS

\author{
CLAYTON ERIK TEIXEIRA
}

\title{
NORMATIZAÇÃO E USO DO TERRITÓRIO NA METRÓPOLE PAULISTANA: O CASO DA OPERAÇÃO URBANA CONSORCIADA ÁGUA BRANCA
}

Versão corrigida

SÃO PAULO

2014 


\section{NORMATIZAÇÃO E USO DO TERRITÓRIO NA METRÓPOLE PAULISTANA: O CASO DA OPERAÇÃO URBANA CONSORCIADA ÁGUA BRANCA}

Dissertação apresentada ao Programa de Pós-Graduação em Geografia Humana, do Departamento de Geografia da Faculdade de Filosofia, Letras e Ciências Humanas da Universidade de São Paulo como requisito para a titulação de mestre em Geografia Humana.

De acordo,

Vanderli Custódio.

Orientadora: Prof. ${ }^{a}$ Dr. ${ }^{a}$ Vanderli Custódio 
Autorizo a reprodução e divulgação total ou parcial deste trabalho, por qualquer meio convencional ou eletrônico, para fins de estudo e pesquisa, desde que citada a fonte.

\section{Catalogação da Publicação \\ Serviço de Biblioteca e Documentação \\ Faculdade de Filosofia, Letras e Ciências Humanas}

TEIXEIRA, Clayton Erik.

Normatização e uso do território na metrópole paulistana: O caso da Operação Urbana Consorciada Água Branca; Orientadora: Vanderli Custódio. São Paulo, 2014, 135 p.

Dissertação (Mestrado - Programa de Pós-Graduação em Geografia Humana) Faculdade de Filosofia, Letras e Ciências Humanas, da Universidade de São Paulo.

1. Operação Urbana Consorciada. 2. Norma. 3. Território Usado. 4. Pluralismo Jurídico. 
Nome: TEIXEIRA, Clayton Erik.

Título: Normatização e uso do território na metrópole paulistana: O caso da Operação Urbana Consorciada Água Branca.

Dissertação apresentada à Faculdade de Filosofia, Letras e Ciências Humanas da Universidade de São Paulo para obtenção do título de mestre em Geografia Humana.

Data da aprovação:

Banca examinadora:

Prof. Dr.:

Instituição:

Assinatura:

Prof. Dr.:

Instituição:

Assinatura:

Prof. Dr.:

Instituição:

Assinatura: 
Aos meus pais Clarck e Aglaé, meus primeiros educadores. Aos meus irmãos, Clarck Jr. e Cláudio, meus primeiros amigos. E aos meus filhos Erick, Patrick e Caique. 


\section{AGRADECIMENTOS}

À Prof. ${ }^{\text {a }}$ Dr. $^{\text {a }}$ Vanderli Custódio pela competência em sua orientação, pela generosidade, encorajamento, compreensão e carinho.

Aos professores Dr. Ricardo Mendes Antas Jr. e Dr. Jaime Tadeu Oliva, que na banca de qualificação contribuíram de forma a refinar os conceitos utilizados e fazendo recomendações valiosas que repercutiram positivamente.

Aos meus filhos Erik, Patrick e Caique e ao meu sobrinho Gabriel pelo apoio e incentivo.

À minha esposa, Vera, pela paciência, por criar condições favoráveis no acolhimento do lar e pela troca de ideias referentes à pesquisa.

Ao meu primo Agilson, pela colaboração na tradução do resumo.

Aos amigos de trabalho na Secretaria do Verde e do Meio Ambiente que contribuíram significativamente em relação às questões técnicas da política ambiental do meu objeto de estudo, Audrey, Carlo, Carolina, Fernanda, João, Eduardo, Matheus, Rosimeire, Raquel, Tatiana e, especialmente, ao Maykon, quem me ajudou em revisão de textos desde o projeto de pesquisa e pela contribuição na elaboração de mapas.

À amiga e professora de graduação Vivian Fiori, que além de incentivar a fazer a pós-graduação, auxiliou-me na elaboração do projeto de pesquisa e revisão de textos.

Aos amigos de graduação pelas conversas frutíferas, em especial à Isabel Perides pela revisão de textos, indicação de leitura e empréstimo de livro, além das conversas descontraídas após as aulas na pós-graduação.

À amiga Suzana Cardoso pelas fotografias utilizadas na dissertação e pela agradável companhia em campo de pesquisa.

Aos agentes mencionados na pesquisa e que contribuíram com depoimentos fundamentais à dissertação, vereadores, representante do SECOVI e da sociedade civil, sobretudo à Sra. Ros Mari Zenha, que abriu as portas de sua casa, convidou-me a participar de reuniões técnicas e disponibilizou documentos que muito auxiliaram em minha pesquisa. 


\section{RESUMO}

TEIXEIRA, C. E. Normatização e uso do território na metrópole paulistana: O caso da Operação Urbana Consorciada Água Branca. 2014. 135 f. Dissertação (Mestrado) Faculdade de Filosofia, Letras e Ciências Humanas, Universidade de São Paulo, São Paulo, 2014.

O objetivo desta dissertação é analisar a implantação da Operação Urbana Consorciada Água Branca, localizada no distrito da Barra Funda, bem como a produção da lei que a regulamenta. Observou-se em campo e em pesquisas a órgãos ligados à Prefeitura Municipal de São Paulo que houve o direcionamento de recursos públicos para o fomento de atividades econômicas em detrimento de demandas sociais na área de estudo. Nossas categorias de análise foram o território usado e a norma, que utilizamos para compreender a construção de uma lei que visa à transformação dos usos do território de passado industrial e que agora incidem propostas de adensamento habitacional e de uso comercial. A produção normativa contou com a participação da sociedade civil, com destaque aos moradores da região e dos promotores imobiliários, mediados pelo Poder Público municipal, caracterizando, assim, um caso de pluralismo jurídico. Por meio das audiências públicas e de entrevistas realizadas com os vereadores, representantes dos moradores da área de estudo e do mercado imobiliário, verificou-se a conflituosa relação entre os diferentes setores da sociedade civil. Desta forma, a norma jurídica, criada em 2013, reflete os desejos e necessidades do uso do território do período atual no município de São Paulo evidenciando as práticas sociais vigentes e as especificidades do distrito da Barra Funda.

Palavras-Chave: Operação Urbana Consorciada; Norma; Território Usado; Pluralismo Jurídico. 


\begin{abstract}
TEIXEIRA, C. E. Standardization and use of the territory in the Metropolis: the case of Joint Urban Operation white water. 2014. 135 f. dissertation (maester) Faculty of Philosophy, Literature and Human Sciences, University of São Paulo, São Paulo, 2014.

The objective of this dissertation is to analyze the implementation of the Joint Urban Operation Agua Branca, located in the Barra Funda district; as well as the creation of the law that governs it. It was observed in the field and research, in this area of study, which was done with bodies linked to the Municipality of São Paulo that public resources were directed to the promotion of economic activities to the detriment of social demands. Our categories of analysis were: the used territory, and the standard, and were used to understand and help in the creation of a law aimed at the transformation of the use of the territory of an industrial past which is now proposed for housing and commercial use. The normative creation also took into consideration the participation of civil society, especially local residents and property developers, mediated by the municipal government, thus characterizing a case of legal pluralism. Through public hearings and interviews with councilors, representatives of the residents of the studied area and the real estate market, it was verified a conflicting relationship between the different sectors of civil society. Thus, the normative (rule of law), created in 2013 , reflects the desires and needs of the use of the territory of the current period (nowadays) São Paulo highlighting current social practices and the specifics of the Barra Funda district.
\end{abstract}

Keywords: Joint Urban Operation, Law, Used Territory; Legal Pluralism. 


\section{LISTA DE MAPAS}

Mapa 1 - Densidade demográfica e localização do perímetro da OUCAB na cidade de São Paulo. 2014 .p. 21

Mapa 2 - Áreas contaminadas (SVMA) dentro da OUCAB. 2014 p.52

Mapa 3 - Zoneamento no perímetro da OUCAB. 2014 _...............................................p.53

Mapa 4 - Drenagem: Córregos e galerias no interior da OUCAB. 2014...................p.55

Mapa 5 - Propostas de OUC após Plano Diretor Estratégico de 2002. 2014..............p.65

Mapa 6 - Proposta de perímetro de estruturação metropolitana do PL nº 688/2013..p.69

\section{QUADRO}

Quadro 1 - Os ciclos do monismo jurídico na sociedade ocidental. 2014 p.33

TABELA

Tabela 1 - Resumo da Movimentação Financeira das OUC em andamento (Janeiro de 2014) .p.70

\section{LISTA DE FOTOS}

Foto 1 - Vista parcial do Shopping Bourbon, esquina da Avenida Francisco Matarazzo com a Avenida Pompéia. 2013 p.58

Foto 2 - Vista parcial da Arena Palmeiras em reforma. 2013 p.58

Foto 3 - Vista parcial do CEAB ao lado da Casa das Caldeiras (antiga indústria da família Matarazzo) e no primeiro plano, parte da ferrovia. 2013 .p.59

Foto 4 - A esquerda um edifício da CEAB e a Casa das caldeiras com suas três chaminés, à direita, empreendimento residencial em construção e no destaque (seta) ao centro, Arena Palmeiras em reforma. 2013. .p.59

Foto 5 - Presença policial coercitiva no despejo de favelados. p. 82

Foto 6 - Desmontagem de moradias. p. 82

Foto 7 - Auditório da CET, onde foi realizada a audiência pública com presença marcante dos moradores da comunidade da Vila Chalot. 2013. .p.94

Foto 8 - Vereador, subprefeito e líder comunitário observando o córrego da Água Branca. 2013 p.95

Foto 9 - Moradores indicando problemas do bairro ao subprefeito. 2013 .p.95

\section{LISTA DE FIGURAS}

Figura 1 - Perímetro da OUCAB antes da retificação do rio Tietê, 1940...................p.21

Figura 2 - Perímetro da OUCAB. 2014 ....................................................................p. 22

Figura 3 - Perímetro da OUAB e da Fábrica dos Sonhos. 2014 .................................p.56 
Figura 4 - Localização do empreendimento Jardim das Perdizes. 2014.....................p.61

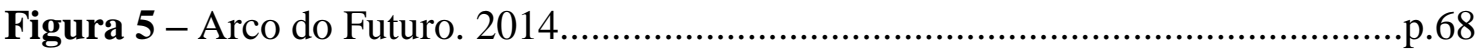

Figura 6 - Setorização do território da OUCAB antes do licenciamento ambiental. 2012 .p.74

Figura 7 - Localização da comunidade água Branca. Obs.: Os lotes numerados correspondem a: 1 - Centro de Treinamento do São Paulo Futebol Clube; 2- Centro de Treinamento da Sociedade Esportiva Palmeiras; 3 - Companhia de Engenharia de

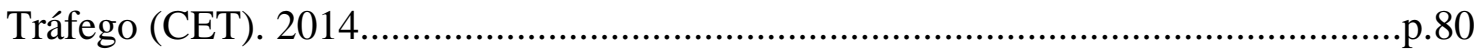

Figura 8 - Nova divisão do território da OUCAB e incentivo de adensamento. 2013. .p.83

Figura 9 - Croqui ilustrativo do perímetro expandido da OUCAB e as ZEIS em seu interior. 2014 p. 85 


\section{LISTA DE SIGLAS E ABREVIAÇÕES}

APP - Áreas de Proteção Permanente

AsBea - Associação Brasileira dos Escritórios de Arquitetura

CADES - Conselho Municipal do Meio Ambiente e Desenvolvimento Sustentável

CEAB - Centro Empresarial Água Branca

CEPAC - Certificados de Potencial Adicional de Construção

CET - Companhia de Engenharia de Tráfego

CETESB - Companhia de Tecnologia de Saneamento Ambiental

CMSP - Câmara Municipal de São Paulo

Conseg - Conselho Comunitário de Segurança

Emurb - Empresa Municipal de Urbanização

EIA - Estudo de Impacto Ambiental

EIV - Estudo de Impacto de Vizinhança

EVA - Estudo de Viabilidade Ambiental

FAU - Faculdade de Arquitetura e Urbanismo

FMI - Fundo Monetário Internacional

GTAC - Grupo Técnico Permanente das Áreas Contaminadas

HIS - Habitação de Interesse Social

IBAMA - Instituto Brasileiro do Meio Ambiente e dos Recursos Naturais Renováveis

MDU - Ministério do Desenvolvimento Urbano

MDC - Mapa Digital da Cidade de SP

MSP - Município de São Paulo

OUAB - Operação Urbana Água Branca

OUC - Operação Urbana Consorciada

OUCAB - Operação Urbana Consorciada Água Branca

OUCVS - Operação Urbana Consorciada Vila Sônia

PDE - Plano Diretor Estratégico

PL - Projeto de Lei

PMSP - Prefeitura Municipal de São Paulo

PPP - Parcerias Público-Privadas

PRE - Plano Regional Estratégico

PSD - Partido Social Democrático 
PT - Partido dos Trabalhadores

PTB - Partido Trabalhista Brasileiro

RIMA - Relatório de Impacto Ambiental

RMSP - Região Metropolitana de São Paulo

SECOVI - Sindicato das Empresas de Compra, Venda e Administração de Imóveis

SIURB - Secretaria de Infraestrutura Urbana

SMDU - Secretaria Municipal de Desenvolvimento Urbano

SPObras - São Paulo Obras

SPUrbanismo - São Paulo Urbanismo

SVMA - Secretaria do Verde e do Meio Ambiente

USP - Universidade de São Paulo

ZEIS - Zona Especial de Interesse Social

ZEPEC - Zona Especial de Preservação Cultural

ZM - Zona Mista 


\section{SUMÁRIO}

Introdução p.14

1. Regulação do território urbano no atual período da globalização. .p.19

1.1 Norma e território usado p. 22

1.1.1 O velho e o novo p. 25

1.1.2 O interno e o externo p. 26

1.2 Uma nova cultura jurídica e as Parcerias Público-Privadas p. 27

1.2.1 Do direito medieval ao monismo jurídico do Estado moderno ocidental.p.28

1.2.2 A crise do monismo e a emergência do pluralismo jurídico p.33

1.2.2.1 A cultura jurídica no Brasil p.37

1.2.3 As Parcerias Público-Privadas p. 41

1.3 Planejamento urbano sob o neoliberalismo e o Empreendedorismo urbano..p.43

1.3.1 Reestruturação urbana em face da reestruturação econômica p. 44

2 A Operação Urbana Consorciada Água Branca...............................................p.48

2.1 Barra Funda e a Operação Urbana Água Branca..............................................p.48

2.1.1 Antecedentes da área....................................................................p. 48

2.1.2 A OUCAB e sua "âncora cultural" ........................................................p.55

2.2 A OUCAB e outras Operações Consorciadas no Município de São Paulo............p.62

3 A OUCAB, os agentes, o pluralismo jurídico e a produção das normas.............p.73

3.1 A discussão no processo de licenciamento ambiental......................................p.73

3.2 A discussão na Câmara Municipal de São Paulo .............................................p.87

Considerações Finais............................................................................................................p.102

Referências bibliográficas......................................................................................p.109

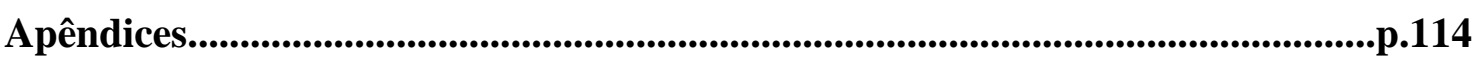

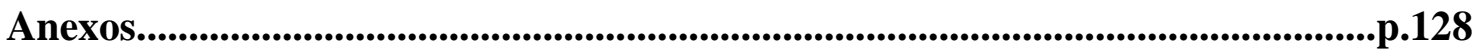




\section{INTRODUÇÃO}

Se observarmos a história da cidade de São Paulo desde o começo do século XX, verificamos a mudança do uso do território por meio da configuração territorial, denominação que Milton Santos (2009a, p. 62) usou para designar o “[...] conjunto formado pelos sistemas naturais [...] numa dada área e pelos acréscimos que os homens superimpuseram a esses sistemas naturais".

Os sistemas técnicos, tais como o bonde, a ferrovia e as vilas operárias, as grandes avenidas, o sistema metroviário e os altos edifícios, são representativos dos diferentes períodos da história recente da capital paulista e nos permite captar a reprodução de seu espaço urbano. Como ressalta a urbanista Raquel Rolnik (2003), neste percurso encontra-se um ordenamento jurídico urbano que regula a produção do espaço. Entretanto, a combinação de normas produzidas pelo Estado acaba por não ter alcance na totalidade do território, vejamos o que argumenta Rolnik (2003, p. 13):

[...] e isto é poderosamente verdadeiro para o caso de São Paulo e provavelmente para a maior parte das cidades latino-americanas, ela determina apenas a menor parte do espaço construído, uma vez que o produto - cidade - não é fruto da aplicação inerte do próprio modelo contido na lei, mas da relação que se estabelece nas formas concretas de produção imobiliária na cidade. Porém, ao estabelecer formas permitidas e proibidas, acaba por definir territórios dentro e fora da lei, ou seja, configura regiões de plena cidadania e regiões de cidadania limitada. [...]

Dessa forma, entendemos que o Estado não é o único produtor de normas, mas divide a função, em maior ou menor medida, com a sociedade em geral, sobretudo, no que Rolnik (2003) chama de territórios fora da lei, ou seja, fora da lei do Estado. Nesses territórios, onde não tem alcance a lei do Estado, normalmente chamado pelo Poder Público de clandestinos ${ }^{1}$, toda a regulação é feita por variados grupos sociais, sob o princípio do pluralismo jurídico, citamos, por exemplo, o caso estudado por Boaventura

\footnotetext{
${ }^{1}$ Integrantes de Gerencia de Regularização de Loteamentos da Procuradoria-Geral do Município de Porto Alegre fazem a seguinte distinção: assentamento irregular é aquele que tem algum tipo de registro no município, mas, de alguma forma não atende o previsto na Lei Federal $n^{\circ} 6.766 / 79$, que dispõe sobre o parcelamento em solo urbano; o assentamento clandestino é realizado sem nenhum conhecimento do Poder Público. Disponível em: http://www.ibdu.org.br/imagens/LOTEAMEN.PDF. Acesso em: 20 mar. 2013.
} 
de Souza Santos $^{2}$, em que descreve a produção jurídica no interior de uma favela do Rio de Janeiro.

A incapacidade do Poder Público em regular o uso do território urbano, contudo, vai além dos territórios clandestinos e abarca a totalidade da cidade de São Paulo. Diante deste cenário surgem as Parcerias Público-Privadas (PPP), investidores privados e a sociedade civil são convidados a participar do planejamento e da gestão de políticas públicas urbanas.

A Operação Urbana, instrumento de intervenção urbanística a ser aplicado em perímetros pré-definidos do território urbano, é associada à PPP no município de São Paulo mesmo antes de sua legitimação pelo Estatuto da Cidade, de 2001.

A Operação Urbana Consorciada Água Branca (OUCAB), desdobramento da lei municipal criada em 1995, é o tema desta pesquisa e nosso objetivo é analisar a sua aplicação e entender como se dá a sua produção normativa, considerando o pluralismo jurídico.

Interessa-nos um estudo sob a luz do território usado, categoria de análise social elaborada por Milton Santos ${ }^{3}$, que o traduz como sinônimo de espaço geográfico, de espaço humano ou espaço habitado. Pensamos que analisar a implantação de um instrumento da política urbana por intermédio da categoria território usado, nos permitirá entender como as formas geográficas pretéritas e presentes intermedeiam e acabam por condicionar as ações e interesses de diferentes agentes sociais, assim como, é por eles condicionado orientando o processo de urbanização pelo qual passa uma parcela da cidade de São Paulo no período atual. Assim, procuramos cumprir a seguinte orientação de M. Santos e María Laura Silveira (2008, p. 21):

[...] Debruçando-nos sobre esse novo meio geográfico, buscamos compreender o papel das formas geográficas materiais e o papel das formas sociais, jurídicas e políticas, todas impregnadas, hoje, de ciência, técnica e informação. [...]

A cidade de São Paulo, que, conforme Paul Singer (1968), teve o processo de urbanização impulsionado pela indústria no início do século $\mathrm{XX}$, passou por um

\footnotetext{
${ }^{2}$ SANTOS, Boaventura de Sousa. O discurso e o poder: ensaio sobre a sociologia da retórica jurídica. Em Boletim da Faculdade de Direito. Universidade de Coimbra, número especial em homenagem ao Prof. Dr. J. J. Teixeira Ribeiro, Coimbra, 1979, pp. 227-341.

${ }^{3}$ Santos, Milton. O retorno do território. In: OSAL : Observatório Social de América Latina. Ano 6 no. 16 (jun. 2005). Buenos Aires: CLACSO, 2005.
} 
crescimento demográfico sem igual no país, de 239.820 habitantes em 1900 a 10.434.252 em 2000 e na primeira década do século XXI houve um acréscimo de 819.251 habitantes, chegando à marca dos $11.253 .503^{4}$.

Uma cidade que cresce nesse ritmo vem enfrentando vários problemas decorrentes do processo de urbanização de uma metrópole fragmentada e corporativa. Conforme Santos (2009b) ela é fragmentada porque isola uma parcela considerável da população em função da imobilidade dentro da cidade, ou seja, problemas de moradia e de transporte, e corporativa porque, ainda segundo Santos (2009b, p. 104): “[...] o Estado utiliza seus recursos para animação das atividades econômicas hegemônicas em vez de responder às demandas sociais [...]", que atualmente não correspondem à predominância da indústria como outrora, mas, da criação de novas divisões do trabalho e da modernização de partes da cidade a fim de atender as demandas dos agentes hegemônicos.

Além dos problemas expostos: imobilidade, segregação social e de corporativismo, intrínsecos da metrópole paulistana, somamos a persistência das inundações verificadas no município, Custódio (2002) demonstra que mesmo com a evolução do ordenamento jurídico sobre o assunto e das ações estruturais, como obras de drenagem, a solução está longe de ser alcançada.

Este dado é fundamental para a nossa pesquisa considerando que mais da metade do perímetro OUCAB se encontra inserido na várzea natural do rio Tietê. Ressaltamos ainda o fortalecimento da promoção imobiliária nas proximidades dos principais rios da capital: Tietê e Pinheiros. Em reportagem publicada na Folha de São Paulo ${ }^{5}$, observa-se que $8 \%$ das unidades residenciais (2.394) lançadas na cidade de São Paulo estão a 500 metros desses dois rios.

Isso significa que a OUCAB deve ser pensada como um projeto de urbanização no interior de um processo maior de urbanização, que abarca toda a Região Metropolitana de São Paulo (RMSP). Por isso, entendemos que o recorte territorial escolhido para nossa pesquisa não se esgota em si mesmo, é apenas um parâmetro.

Para dar conta da nossa proposta, realizamos os seguintes procedimentos metodológicos:

\footnotetext{
4 Dados da Prefeitura do Município de São Paulo. Disponível em: http://smdu.prefeitura.sp.gov.br/historico_demografico/tabelas/pop_evo.php. Acesso em: 21 mar. 2013.

${ }^{5}$ Disponível em: http://www1.folha.uol.com.br/fsp/cotidian/ff2302201111.htm. Acesso em: 21 mar.2013.
} 
a) Compreensão do que seja o pluralismo jurídico, sobretudo, nos trabalhos do jurista Antônio Carlos Wolkmer, do jusfilósofo José Eduardo Faria e do sociólogo Boaventura de Souza Santos;

b) Consulta da legislação acerca da intervenção urbana estudada, com destaque à legislação Federal sobre a política urbana e Municipal sobre a ocupação e uso do solo;

c) Verificação, em campo, dos procedimentos da sociedade civil que se organiza por meio de reuniões e mantém um blog para comunicação; entrevistamos líderes comunitários e a representante da sociedade civil no Conselho Municipal do Meio Ambiente e Desenvolvimento Sustentável (CADES), órgão consultivo e deliberativo com participação na revisão da lei que criou a OUCAB, entrevistamos também um representante do setor imobiliário do Sindicato das Empresas de Compra, Venda e Administração de Imóveis (SECOVI), que também atua no CADES;

d) Levantamento de dados em órgãos públicos ligados ao Poder Executivo Municipal, entre eles a empresa pública responsável por dar suporte às ações de planejamento urbano, a São Paulo Urbanismo (SP Urbanismo), a Secretaria Municipal de Desenvolvimento Urbano (SMDU) e a Secretaria do Verde e do Meio Ambiente (SVMA), além de participação de reuniões técnicas e audiências públicas por eles realizadas;

e) Entrevista com vereadores, leitura do Processo que trata do Projeto de Lei (PL) da OUCAB tramitado na Câmara Municipal de São Paulo (CMSP) e acompanhamento de audiências públicas realizadas no legislativo.

Estamos organizando os resultados da pesquisa de nossa dissertação em três capítulos, no primeiro discutimos sobre a regulação do território urbano no atual período da globalização, que trata do referencial teórico com relevo ao conceito de norma.

No segundo, tivemos a preocupação de analisar a normatização e o uso do território no Município de São Paulo, com a preocupação de tratar do ordenamento normativo que regula o espaço urbano da metrópole. Fizemos um histórico do uso da área afetada pela OUCAB e um breve relato das demais Operações Urbanas realizadas na capital paulista e como essa reestruturação urbana dialoga com a revisão do Plano Diretor Estratégico (PDE) do Município de São Paulo (MSP). No terceiro e último 
capítulo analisamos a produção da norma jurídica propriamente dita, a lei que regula a operacionalidade da OUCAB. Dividimos este capítulo em duas partes, na primeira demonstramos o impulso dado pelo Poder Executivo na elaboração da lei a partir da discussão inicial sobre o licenciamento do plano urbanístico proposto, na segunda parte, exibimos o trâmite ocorrido na CMSP marcado pela influência da sociedade civil, no qual evidenciamos como as ações se dão sob a mediação do território e do sistema normativo e, por fim, tecemos as Considerações Finais. 


\section{REGULAÇÃO DO TERRITÓRIO URBANO NO ATUAL PERÍODO DA GLOBALIZAÇÃO}

Tendo em vista que a política urbana no Brasil deve ser realizada segundo os preceitos do Estatuto da Cidade $^{6}$, de 2001, ordenamento jurídico federal que estabelece diretrizes gerais da política urbana, analisaremos a aplicação de um de seus instrumentos na cidade de São Paulo, a Operação Urbana Consorciada, tratado nos artigos 32 a 34 do referido Estatuto e que se define como:

[...] o conjunto de intervenções e medidas coordenadas pelo Poder Público municipal, com a participação dos proprietários, moradores, usuários permanentes e investidores privados, com o objetivo de alcançar em uma área transformações urbanísticas estruturais, melhorias sociais e a valorização ambiental. (BRASIL, 2001).

Na capital paulista já existiam modalidades de Operação Urbana desde a década de 1990, são elas: a) Operação Urbana Anhangabaú (1991), que se extinguiu; b) a Operação Urbana Faria Lima (1995); c) a Operação Urbana Água Branca (1995); d) e a Operação Urbana Centro (1997); entretanto, com o estabelecimento do Estatuto da Cidade, as leis que as criaram precisaram de revisão a fim de se adequar com a lei federal. Ressalta-se que a Operação Urbana Consorciada Água Espraiada, por ter sido aprovada após o estabelecimento do Estatuto da Cidade, é a única que surge como Consorciada e utiliza os dispositivos da lei federal.

As propostas citadas de Operações Urbanas no município de São Paulo foram motivadas por razões distintas, posto que o uso do território condicione a diferentes necessidades. Por exemplo, a Operação Urbana Consorciada Faria Lima tem por objetivo principal a reestruturação viária e o prolongamento da Avenida Faria Lima enquanto a Operação Urbana Consorciada Água Branca (OUCAB) trata de um conjunto de intervenções mais complexas por se referir a uma área inserida na várzea natural do rio Tietê, favorável a inundações, com histórico de ocupações industriais, contendo grandes glebas vazias onde o que se busca é o adensamento demográfico ${ }^{7}$.

Diante das especificidades de cada uma dessas intervenções na cidade de São Paulo, optamos por analisar a implantação da Operação Urbana Consorciada Água

\footnotetext{
${ }^{6}$ Lei Federal n ${ }^{\circ} 10.257$ de 2001.

${ }^{7}$ Informações disponíveis no sítio eletrônico da Secretaria Municipal de Desenvolvimento Urbano em: http://www.prefeitura.sp.gov.br//cidade/secretarias/desenvolvimento_urbano/. Acesso em: 24 fev. 2013.
} 
Branca (OUCAB) ${ }^{8}$, desdobramento da Operação Urbana Água Branca (OUAB), de 1995. Nesse período houve mudanças significativas em relação às exigências legais sobre a participação social, que pretendemos analisar.

O mapa 1 , a seguir, expõe a densidade demográfica por distrito $\left(\mathrm{n}^{\circ}\right.$ de habitantes por $\mathrm{km}^{2}$ ) e a localização do perímetro da OUCAB, próximo da região central da cidade de São Paulo, dessa forma observamos que a área escolhida para a intervenção urbanística apresenta uma das menores taxas de densidade demográfica do município.

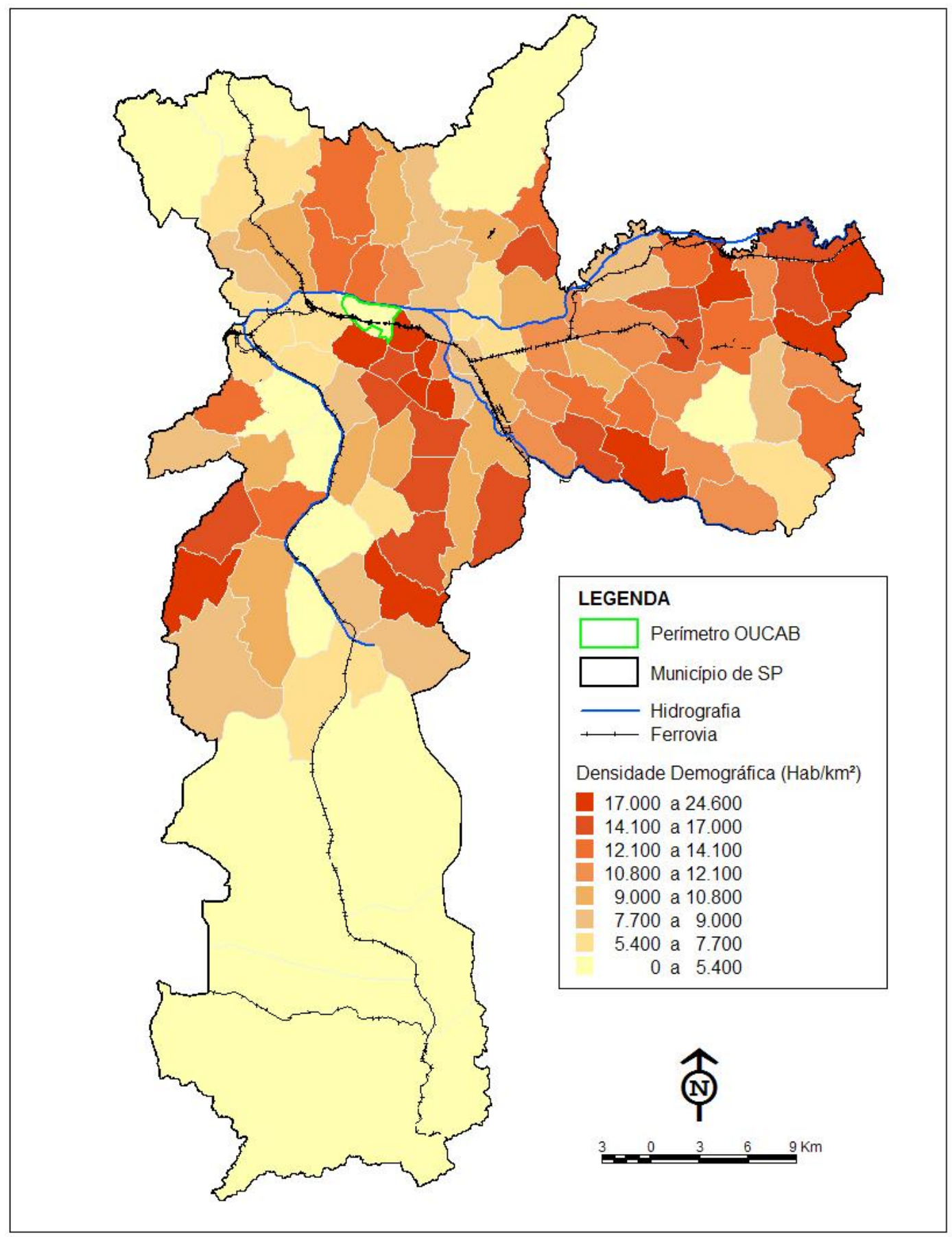

\footnotetext{
${ }^{8}$ Lei municipal $n^{\circ} 11.774 / 1995$.
} 
Mapa 1 - Densidade demográfica e localização do perímetro da OUCAB na cidade de São Paulo. Elaboração própria ${ }^{9} .2014$

A baixa densidade demográfica no perímetro em tela pode ser explicada pelos fatores que condicionaram o processo de ocupação. A figura 1, referente a fotos aéreas de 1940, antes da retificação do rio Tietê, evidencia as marcas deixadas pelos meandros do rio Tietê indicando que o local é uma área de várzea de inundação natural, o que restringia a ocupação para fins de moradia ou atividades industriais. A ocupação era limitada pela ferrovia.

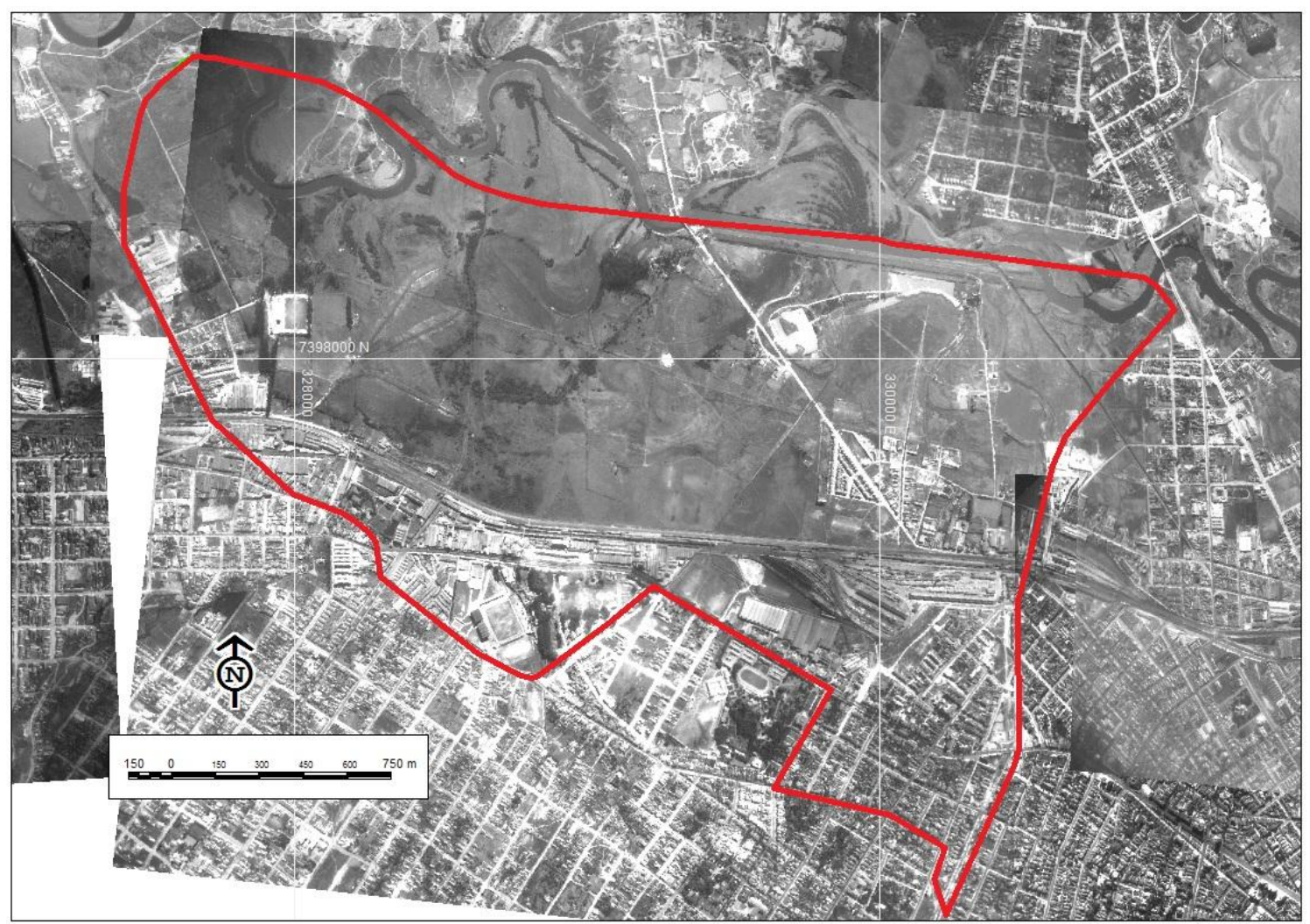

Figura 1 - Perímetro da OUCAB antes da retificação do rio Tietê, 1940. Elaboração própria ${ }^{10}$. 2014

Atualmente, conforme figura 2, verificamos grandes glebas no interior do perímetro da OUCAB, revelando seu passado industrial. A ocupação observada foi possibilitada pela retificação do rio Tietê.

\footnotetext{
${ }^{9} \mathrm{O}$ mapa foi elaborado utilizando o programa de SIG Mapinfo (Professional version 9.5; Mapinfo Corporation, New York, NY, USA). Projeção cartográfica UTM, Datum Planimétrico SAD 69, Hemisfério Sul, fuso 23. Fonte: Mapa Digital da Cidade de São Paulo (MDC) e Instituto Brasileiro de Geografia e Estatística (IBGE), Censo 2010.

${ }^{10}$ Acervo da Prefeitura do Município de São Paulo (PMSP), fotos de junho de 1940. Por falta de tecnologia à época, há algumas distorções e recombrimento imperfeito do terreno. Nas imagens de elaboração própria foi utilizado o programa de SIG Mapinfo (Professional version 9.5; Mapinfo Corporation, New York, NY, USA).
} 


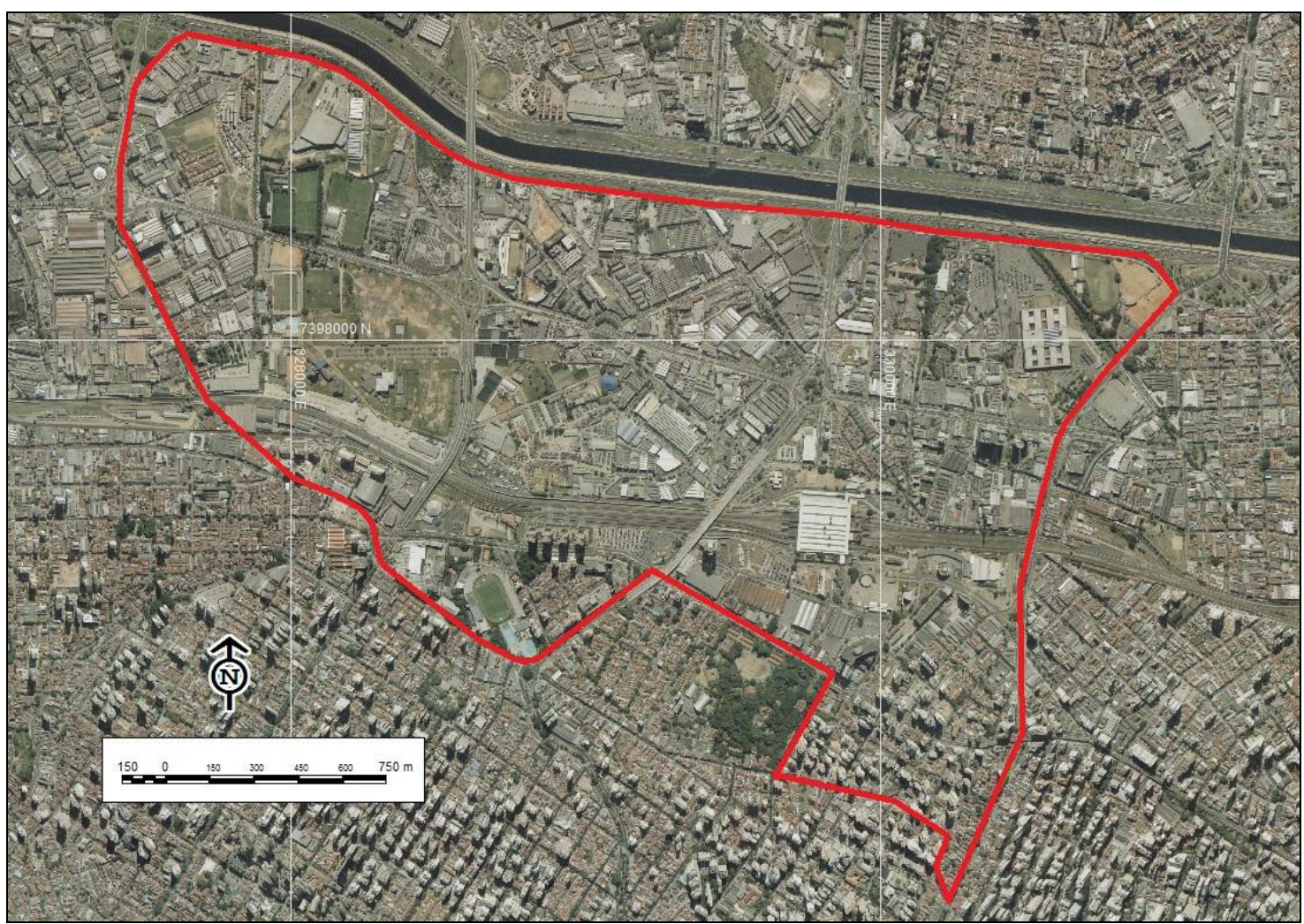

Figura 2 - Perímetro da OUCAB. Elaboração própria ${ }^{11} .2014$

Tendo o território como mediador, o Estado, a sociedade civil e o mercado imobiliário desenvolvem um sistema normativo, cada um com suas necessidades específicas diante das transformações pretendidas no perímetro da OUCAB. Por isso, nos debruçaremos sobre um arcabouço teórico que contemple nossa pesquisa a partir da análise da produção normativa.

\subsection{Norma e território usado}

O conceito central de nossa pesquisa será a norma, conceituada por Milton Santos e aprofundada pelo geógrafo Ricardo Mendes Antas Jr., o qual afirma que a norma ao lado da técnica faz do espaço geográfico uma instância social (ANTAS JR, 2005).

Segundo Antas Jr. (2005), a técnica e a norma são elementos constitutivos do espaço geográfico proposto por Milton Santos, contudo, embora a norma apareça com frequência em seus últimos trabalhos, era de maneira distante da produção teórica jurídica. Antas Jr. (2005) realizou um trabalho teórico a fim de aprofundar o significado da norma a partir do diálogo entre a geografia e a ciência jurídica buscando uma equiparação entre o papel da técnica e da norma.

\footnotetext{
${ }^{11}$ Empresa Paulista de Planejamento Metropolitano S/A (Emplasa), Ortofotos 2007.
} 
Antes, porém, de discorrer sobre a norma, esclarecemos que o espaço geográfico mencionado é aqui entendido como sinônimo de território usado, conforme Santos (2005, p. 255) “[...] território são formas, mas o território usado são objetos e ações, sinônimo de espaço humano, espaço habitado [...]". O espaço geográfico proposto por Santos pressupõe, portanto, um sistema de objetos e um sistema de ações ou como diz o próprio autor: "O espaço é formado por um conjunto indissociável, solidário e também contraditório, de sistemas de objetos e sistemas de ações, não considerados isoladamente, mas como o quadro único no qual a história se dá." (SANTOS, 2009a, p.63).

Vale ressaltar que os objetos de que trata Santos (2009a) são os objetos geográficos, tudo que se encontra e que se cria fora do homem, herança da natureza e da produção humana e que serve de instrumento material para sua vida, logo, o objeto geográfico é necessariamente um objeto social com uma funcionalidade ou apenas simbólico, podendo ser uma casa ou uma cidade inteira e ainda um lago e uma montanha.

Entretanto, o autor ressalta que:

Trata-se de reconhecer o valor social dos objetos, mediante um enfoque geográfico. A significação geográfica e o valor geográfico dos objetos vem do papel que, pelo fato de estarem em contiguidade, formando uma extensão contínua, e sistemicamente interligados, eles desempenham no processo social. (SANTOS, 2009a, p. 49)

Nessa perspectiva, para a geografia, o que vale é o objeto considerado pelo seu uso, o que o torna, também, um objeto técnico mesmo que encontrado e criado na e pela natureza: “[...] para os fins de nossa análise, mesmo os objetos naturais poderiam ser incluídos entre os objetos técnicos, se é considerado o critério do uso possível [...]" (SANTOS, 2009a, p. 38). Mas um objeto não pode ser considerado isoladamente, como menciona Santos (2009b), ou seja, todo objeto geográfico, assim o é porque faz parte de um sistema de objetos que lhe dá condições de ser usado com a finalidade da qual lhe é atribuída.

É nesse sentido que Santos (2009a), a fim de captar o todo como realidade e processo, como uma totalização, pensa o espaço geográfico como um sistema de objetos indissociável de um sistema de ações, pois são as ações que conferem o conteúdo social aos objetos. 
As ações se dão intencionalmente, com um objetivo previamente pensado e sempre visando aos objetos, por isso as ações são indissociáveis dos objetos. Para Santos (2009b, p. 78) "[...] a ação é subordinada a normas, escritas ou não, formais ou informais [...]", pois a ação humana condiciona o espaço geográfico, mas, é também por ele condicionado.

As ações, segundo Antas Jr. (2003), só são possíveis por intermédio de objetos técnicos e são orientadas por um ordenamento de normas, sobretudo no período atual, no qual as ações são mais complexas. E da perspectiva da geografia, define a norma como:

[...] o resultado da tensão e/ou da harmonia entre objetos e ações que constituem o espaço geográfico; dito de outro modo, como decorrência da indissociabilidade entre configuração territorial e uso do território, determinantes de diferentes tipos de normas. (ANTAS JR., 2005, p. 61)

Antas Jr. (2005) identifica três grupos de tipos de normas que derivam da interação entre objetos e ações: a) as normas provenientes dos objetos técnicos que regulam as ações; b) a norma das ações que em função de uma necessidade incide sobre o uso dos objetos técnicos; e c) a norma que limita as possibilidades de uso de um objeto ou de um sistema de objetos, esta norma surge da necessidade de um grupo que dispõe de constrangimentos para validá-la, é a norma que corresponde à norma jurídica.

Desta forma, Antas Jr. traz para a geografia uma discussão já existente em outras áreas das ciências humanas sobre o pluralismo jurídico contemporâneo. A cerca do pluralismo jurídico, citamos nesta dissertação alguns dos trabalhos dos juristas Antônio Carlos Wolkmer e José Eduardo Faria, do sociólogo Boaventura de Souza Santos e do antropólogo Robert Weaver Shirley. Nesta compreensão sobre o direito o Estado não é o único detentor da regulação social, mas divide a função de regulador com poderes distintos relacionados ao uso do território como as grandes corporações privadas e a sociedade civil organizada em associações.

Ensina-nos ainda Antas Jr. (2005) que o direito sob a perspectiva da geografia deve considerar dois pressupostos: a) ser entendido como instância social e não como ciência aplicada; e que b) as formações territoriais estão estreitamente ligadas aos modelos de direito. A construção das diferentes formas de direito ao longo da história caracterizam-se de acordo com a formação social, cultural, econômica, etc., ratificandoa como instância social. Quanto às formações territoriais, Antas Jr. (2005) destaca que a noção de território nacional, por exemplo, tem operacionalidade em função de um 
sistema jurídico, trata-se de uma forma geográfica, mas, também uma forma jurídica e uma pode ser produzida pela outra.

A interação entre território e norma não é restrita à escala nacional, pode ser reproduzida em diferentes escalas, no caso de uma intervenção urbanística, podem-se identificar necessidades coletivas e socais como demanda por moradia, por emprego, por equipamentos sociais (escolas e hospitais, por exemplo) e as demandas impostas pela configuração territorial, a partir da qual se constitui uma legislação fundiária específica tanto para se preservar patrimônios ambientais, históricos e culturais como para a recuperação de áreas degradadas.

É dessa perspectiva que analisamos a implantação da Operação Urbana Consorciada Água Branca (OUCAB), que objetiva adequar a norma municipal de 1995, conferindo-lhe a característica "Consorciada", mas que se implanta de maneira lenta em relação a outras Operações Urbanas ${ }^{12}$ da capital paulista, sob o conflito das ações do Estado, das corporações do ramo da construção civil e mercado imobiliário e da sociedade civil. Há um intrincado sistema de normas jurídicas, técnicas e morais que regulam a produção e o uso do território no perímetro da OUCAB, resultado de intenções conflituosas.

Além da relação entre o Estado, o mercado e a sociedade civil, consideramos ainda os elementos contraditórios que, conforme, Santos (2008a) se referem ao fato geográfico: o velho e o novo, o interno e o externo.

\subsubsection{O velho e o novo}

Paul Singer (1968) ao estudar sobre a evolução urbana no município de São Paulo constata que com a necessidade de escoamento da produção do café se introduz a ferrovia, que ao lado de outros objetos técnicos da época como o bonde a fábrica e a vila operária, por exemplo, formou um sistema técnico próprio do começo do século XX indutor de certa forma urbana na capital, como o que caracterizou o distrito da Barra Funda, local da implantação da OUCAB.

A partir da década de 1920, segundo Raquel Rolnik (2003), inicia-se na capital paulista a produção dos projetos viários pelo Estado, rompendo a rigidez imposta pela

\footnotetext{
${ }^{12}$ São elas: a Operação Urbana Faria Lima (1995), que já teve sua principal intervenção executada, e a Operação Urbana Consorciada Água Espraiada (2001), que também conta com algumas intervenções executadas.

http://www.prefeitura.sp.gov.br/cidade/secretarias/upload/desenvolvimento_urbano/sp_urbanismo/arquiv os/cepac/oucae_prospecto.pdf (Acesso em: 24 fev. 2013).
} 
ferrovia e formando um novo sistema técnico atendendo a novas necessidades e aumentando a velocidade dos fluxos internos da cidade. $\mathrm{O}$ indutor neste novo período técnico é a indústria automobilística. Desde então se verifica na cidade o processo de periferização que se intensifica nas décadas de 1960 e 1970 seguido, a partir de então, da intensificação da verticalização (SOUZA, 2010), acompanhada de um novo sistema técnico.

Os sistemas técnicos de diferentes períodos passam a coexistir de maneira a evidenciar a modernização incompleta do território ou nos dizeres de Santos (2009b, p. 15) “"...] Tudo o que há de mais moderno pode aí ser encontrado, ao lado das carências mais gritantes". Para Santos (2009c) os países periféricos que querem participar da modernização contemporânea e se inserir no processo de globalização passam a investir em infraestrutura em detrimento de investimentos sociais, resultando numa modernização seletiva excluindo significativa parte da atividade urbana e da população.

Algumas áreas da cidade não só envelhecem precocemente e se desvalorizam como também passam a ser um entrave aos novos processos produtivos, dada sua rigidez, caso da Barra Funda, distrito aqui estudado, enquanto outras áreas apresentam traços de opulência explicitando um grande contraste socioeconômico.

A OUCAB, portanto, surge, em parte, como demanda da interação entre o "velho" e o "novo".

\subsubsection{O interno e o externo}

Dada a característica informacional do período técnico atual, podemos afirmar que o externo incide sobre o interno com facilidade. Todavia, Santos (2008a, p. 106) nos alerta que a "[...] eficácia do mesmo fator externo varia segundo os lugares, os valores internos a estes [...]", ou seja, as variáveis internas podem servir tanto de facilitadores aos fatores externos, quanto de resistência sobre a organização local.

Como variáveis internas, consideramos a técnica, conforme nos sugere Santos (2008b) nas formas espaciais com sua dimensão material e nas formas dos comportamentos obrigatórios (normativas), ou seja, as formas jurídicas e as formas sociais.

Cada perímetro de Operação Urbana na capital paulista tem se implantado de maneira diferente devido aos fatores locais distintos. No caso da OUCAB, a desconcentração industrial foi determinante. 
Verificamos em Milton Santos e María Laura Silveira (2008) que a modernização técnica, os novos dados normativos (incentivos fiscais, por exemplo) e interesses políticos marcam a intensificação da instalação de indústrias no interior do estado de São Paulo e uma diminuição relativa de estabelecimentos na capital e na $\mathrm{RMSP}^{13}$.

Assim sendo, diante do processo de mundialização da economia, São Paulo passa a ser alvo de novas estratégias com a finalidade de torná-la competitiva em relação às grandes cidades do mundo. Mariana Fix (2001) argumenta que a promoção mundial das cidades passa a ser central na busca por investimentos estrangeiros e esta promoção implica em preparar certas áreas da cidade, preferencialmente aquelas dotadas de infraestrutura urbana, com a finalidade de transformá-las em novos polos de desenvolvimento, poder e riqueza mundiais.

Em São Paulo, essas áreas coincidem com os perímetros das Operações Urbanas, e a OUCAB é o melhor exemplo de uma transformação em função da obsolescência de um sistema técnico predominante (indústria e ferrovia) em que o processo de mundialização da economia incide diretamente.

\subsection{Uma nova cultura jurídica e as Parcerias Público-Privadas}

Conforme foi mencionado no item anterior, a intervenção urbanística ora analisada demanda um sistema de normas jurídicas, técnicas e morais colocando em confronto os interesses e desejos da sociedade civil, do Estado e dos investidores do ramo imobiliário. A fim de entender esse conflituoso processo, buscamos algumas contribuições no direito acerca do pluralismo jurídico contemporâneo, assim procuramos, a exemplo do trabalho de Antas Jr. (2005), afastar a premissa frequente na ciência geográfica de que o Estado seja o único produtor de normas e responsável por toda a regulação social.

Procuramos, todavia, nos atentar à teoria geográfica ora proposta, considerando como nos alerta Antas Jr. (2005) para o fato de que muitas das particularidades da ciência jurídica não serem próprias da formação do geógrafo.

\footnotetext{
13 “[...] Enquanto em 1970 a Região Metropolitana reunia 36,09\%, o município de São Paulo 28,94\% e o interior apenas $6,95 \%$ no total nacional dos estabelecimentos industriais, duas décadas mais tarde as participações respectivas eram de 21,95\%, 9,23\% e 15,26\% [...]" (LENCIONI, 1991, apud SANTOS; SILVEIRA, 2008).
} 


\subsubsection{Do direito medieval ao monismo jurídico do Estado moderno ocidental}

Nossa intenção primeira é evidenciar, sem o rigor da historiografia, mas, fazendo uso de fatos históricos como contribuição para o estudo geográfico proposto, de como os princípios do monismo jurídico (quando o Estado é o único produtor de normas) se consolidaram com a ascensão da sociedade burguesa e com o fim das relações feudais. Posteriormente, veremos como esses mesmos princípios do monismo jurídico dão sinais de crise, abrindo espaço para o pluralismo jurídico, a partir das transformações ocorridas nas últimas décadas do século $\mathrm{XX}$ impulsionadas pelo processo de globalização do sistema capitalista, vale dizer os conflitos sociais, as crises econômicas, o surgimento de um novo sistema técnico entre outras.

A história da cultura jurídica é baseada, conforme Antônio Carlos Wolkmer (2001), na história da formação social, nos modos de produção, na ideologia política e no modelo de organização político-institucional ou como menciona o autor, no modelo da instância maior de poder.

Dessa maneira, o início e fortalecimento do monismo jurídico na sociedade moderna do ocidente são associados ao surgimento da sociedade burguesa em contraponto ao direito medieval, a transição de um modelo jurídico ao outro é assim resumido por Wolkmer (2001, p. 28) afirmando que ocorria na Idade Média:

[...] a existência do pluralismo normativo das corporações em cujos marcos ocorre uma justiça administrada em tribunais criados pelo senhor feudal e pelo proprietário nominal da terra. Posteriormente, em face das exigências de regulamentação e controle da nova ordem econômica mercantilista e de proteção aos intentos imediatos da nascente burguesia comercial, a antiga estrutura descentralizada de produção jurídica é sucedida pela consolidação mais genérica sistemática e unitária de um Estado Mercantil.

Isso não significa que se rompe completamente com as influências das formas de direito anteriores, Antas Jr. (2005) destaca que o direito romano coexistiu e sofreu modificações na Idade Média por causa das regressões nos domínios territoriais, onde se praticavam outras formas de direito (o direito canônico, o direito feudal, o direito real, o direito dominial, o direito urbano e o jus mercatorum).

José Reinaldo de Lima Lopes (2000) lembra que nos reinos bárbaros durante a Idade Média, duas formas de direito se estabelecem, o direito dos bárbaros, baseado na consolidação dos costumes e o direito romano barbarizado ou vulgarizado. Michael 
Foucault (1996) denomina o direito bárbaro de direito germânico, dada a característica germânica ser predominante entre os direitos estabelecidos entre os reinos bárbaros, no qual o sistema de inquérito era inexistente e os litígios eram colocados à prova pela força, mas também poderiam ser negociados economicamente. Tanto Lopes (2000) como Foucault (1996) acrescentam que por volta do século XII, o direito germânico deixa de ser predominante no ocidente diante do reaparecimento do direito romano.

Outra distinção relevante ao estudo geográfico entre as formas de direito mencionadas, destacada por Antas Jr. (2005), é em relação a uma nova formação territorial acompanhada de incipiente estrutura estatal, segundo Foucault (1996), quando essa conjugação ocorria o direito romano se revitalizava, uma forma de direito mais complexo, portanto, sobressaia-se, baseada no inquérito, enquanto nas sociedades germânicas as formas jurídicas eram mais rudimentares. O inquérito é uma forma de pesquisar e fundamentar a verdade, como explica Foucault (1996, p. 12) ou com suas palavras: "[...] Foi para saber exatamente quem fez o quê, em que condições e em que momento, que o Ocidente elaborou as complexas técnicas do inquérito [...]".

Destarte, a fusão entre as duas formas de direito constituiu o direito romanogermânico, atualmente predominante, embora não exclusivo, na Europa e na América Latina, conforme Antas Jr. (2005, p. 85), que assim o descreve:

[...] uma necessária fusão entre as práticas sociais de uso do território, o que de modo geral os juristas e estudiosos do direito denominam de costume, e uma racionalidade lógica e formalista que procurava sistematizar e conceituar, o quanto fosse possível, esses direitos produzidos localmente [...] Aqueles costumes que não pudessem ser assim generalizados acabaram, por força da coerção ou da falta de sentido, sendo suprimidos ou caindo em desuso.

O inquérito como levantamento da verdade, veio ao encontro das necessidades políticas para a transição da formação do Estado feudal para o Estado absolutista. Antas Jr. (2005) esclarece que entre os séculos XIII e XVIII foram se delimitando os territórios nacionais, tal como os conhecemos hoje, a partir de uma característica fundamental do direito romano-germânico, a homogeneização das práticas sociais e econômicas, o que facilitava a compreensão das ações mercantis em territórios extensos aumentando o poder de controle do rei sobre um território específico. Quando o Estado monopoliza a justiça, ou seja, se apropria da nova construção jurídica, passa a definir um perímetro territorial, no qual esse sistema jurídico será condição de garantia de 
justiça para os súditos com o alcance da produção da verdade em todo o território, por meio do inquérito.

Ao se apropriar das práticas jurídicas baseadas no inquérito, o Estado estabelece mecanismos de reparo ou de punição contra os infratores baseados no confisco de terras e criação de impostos o que fortaleceria a soberania, o aumento territorial e a riqueza das monarquias recém-formadas (FOUCAULT, 1996). A criação de fronteiras, lembra Antas Jr. (2005), seria o impulso para a nova classe mercantil, que estaria protegida dos mercadores estrangeiros.

A nova teoria política e jurídica, segundo Lopes (2000), se afina com a noção de soberania e do pacto de sujeição dos súditos ao soberano com as publicações de Maquiavel, Jean Bodin, Thomas Hobbes, todos ligados ao jusnaturalismo ${ }^{14}$ (filosofia natural do direito) e ao absolutismo, “[...] em Hobbes [...] o Estado assume o direito e não restam direitos aos súditos, senão aqueles reconhecidos pelo soberano [...]" (LOPES, 2000, p. 192), ratificando os princípios do monismo jurídico.

O contexto dessa nova filosofia é marcado por condutas racionalista, personalista e individualista, essa última obriga que a organização social aconteça por meio de contratos, adicionando, portanto a característica contratualista ao direito. Lopes (2000) chama a atenção para as tendências do novo direito, qual sejam a paz (e não a justiça) e a prosperidade econômica conectadas à liberdade moderna. ${ }^{15}$

Uma relação simbiótica se forma entre a edificação desse novo Estado e a crescente classe burguesa, para Karl Marx e Friedrich Engels (1999), as transformações nos modos de produção animadas pela abertura de novos mercados e de um novo sistema técnico, levaria os novos industriais a suplantarem os produtores artesanais e trabalhadores independentes. A burguesia subordinou os camponeses, os reinos bárbaros, aglomerou a população em centros urbanos, centralizou os meios de produção e concentrou a propriedade fundiária.

A consequência, ainda para Marx e Engels (1999, p.15) foi a centralização política, “[...] em um só governo, uma só lei, um só interesse nacional de classe [...]”, o

\footnotetext{
14 "[...] direito natural (ou jusnaturalismo): doutrina segundo a qual o homem, todos os homens, indiscriminadamente, têm por natureza e, portanto, independentemente de sua própria vontade, e menos ainda da vontade de alguns poucos ou de apenas um, certos direitos fundamentais, como direito à vida, à liberdade, à segurança, à felicidade - direitos esses que o Estado, [...] detêm o poder legítimo de exercer a força para obter a obediência a seus comandos devem respeitar, e, portanto não invadir, e ao mesmo tempo proteger contra toda possível invasão por parte dos outros." (BOBBIO, 2011b, p. 11).

${ }^{15}$ Chamada por Jean-Jacques Rousseau (2011), em sua obra Do Contrato Social, de liberdade civil e liberdade moral, limitada pela vontade geral a partir de um pacto social e sob a soberania do Estado.
} 
que se traduz para Wolkmer (2001) na doutrina do monismo jurídico, um sistema racional lógico-formal centralizador do direito produzido apenas pelo Estado.

Além da criação de fronteiras darem o impulso à classe burguesa como foi mencionado, outros dois eventos foram de suma importância para a transformação do Estado absoluto, conformação do Estado Moderno e a consolidação da burguesia, são eles: a Reforma Protestante e a descoberta do Continente Americano.

Sobre a pluralidade religiosa que se instala em função da Reforma, Lopes (2000), argumenta que os Estados nacionais passam a discutir formas de lidar com a tolerância religiosa antes mesmo de debater acerca da democracia e do dissidente político, a solução também nesse caso foi o jusnaturalismo.

Outrossim, para Max Weber (2001) a Reforma foi fundamental para que os princípios dos novos modos de produção baseados no incipiente capitalismo de mercado tivessem boa receptividade entre a sociedade da época, pois se considerava a racionalidade como traço fundamental desta, salientando que o protestantismo atribuía mérito à vocação natural para o trabalho e ao bom uso da renda que poderia levar o homem à salvação individual, ao contrário do catolicismo, que pregava o desprendimento material.

Simultaneamente, a descoberta do Continente Americano fortalecia o mercantilismo, base de sustentação do absolutismo, embora tenha servido também de condição para a ascensão da burguesia, que mais tarde reclamaria o poder sustentado pelo capitalismo industrial e sob os auspícios da filosofia do Liberalismo ${ }^{16}$.

Desta forma, alcançamos a finalidade a que nos propusemos neste item e verificamos que a edificação da cultura jurídica baseada no monismo surge e vai se consolidando no ocidente desde a formação do Estado nacional. Mesmo com as transformações político-ideológicas, os princípios do monismo jurídico são as bases do Estado soberano.

Dito isto, podemos passar, de maneira sucinta, ao longo das transformações político-ideológicas que se sucederam e das respectivas fases do sistema capitalista até o período atual, para entendermos como os fundamentos do monismo jurídico entram em crise.

\footnotetext{
${ }^{16}$ Conforme Bobbio (2011b, p. 18) "[...] o Estado liberal se afirma na luta contra o Estado absoluto em defesa do Estado de direito e contra o Estado Máximo em defesa do Estado mínimo, ainda que nem sempre os dois movimentos de emancipação coincidam histórica e praticamente."
} 
A emergência do Estado intervencionista, conforme salienta Wolkmer, coincide com a etapa do capitalismo monopolista-financeiro, “[...] marcado pela constituição, evolução e posterior crise do Estado do Bem-Estar [...]" (WOLKMER, 2001, P. 44). O que se segue é a formação de blocos econômicos e políticos com integração de mercados e a hegemonização das corporações internacionais, numa fase do capitalismo globalizado, abrindo espaço para a crise do monismo jurídico, notemos:

[...] Tendo em conta esta trajetória mais recente é que cabe visualizar também as transformações que atravessaram o estado Capitalista, as formas de descentralização do poder, a crescente presença de novos sujeitos participantes e a especificidade de pólos normativos insurgentes e informais que expressam a retomada de certas práticas pluralistas [...]. (WOLKMER, 2001, p. 44)

Sobre os "polos normativos insurgentes", o autor se refere aos grupos sociais marginais, lideranças e movimentos radicais. Wolkmer (2001, p. 45) alega que a ocorrência jurídica na sociedade moderna ocidental, como já mencionado em Antas Jr. (2005), manifestou-se mediante dois modelos judiciais, “[...] Civil Law (Direito escrito produzido diretamente pelo Estado) e pela Commom Law (Direito dos Juízes, expressão indireta da vontade estatal) [...]”, modelo existente na Inglaterra, nos Estados Unidos, parte do Canadá e Austrália ${ }^{17}$, que resulta de costumes reconhecidos pela ordem estatal.

Diante do exposto, observa-se, que a edificação do Direito moderno tem suas bases na formação social, econômica e cultural de um dado período e consequentemente dois objetivos: a) a legalidade estatal e b) a centralização burocrática. A partir dessa premissa elaboramos o quadro 1, exposto a seguir, com a intenção de expressar resumidamente a teorização de Wolkmer (2001) acerca do monismo jurídico no Estado moderno. Entretanto, por mais que seja indiscutível a predominância do monismo jurídico, Wolkmer (2001) assegura que não se pode desconsiderar a produção de ordenamentos jurídicos fora do Estado, entre eles o Direito Eclesiástico e o Direito Internacional.

\footnotetext{
${ }^{17}$ Antas Jr. (2005) expõe um mapa com a territorialização das principais concepções de direito no mundo.
} 
Quadro 1: Os ciclos do monismo jurídico na sociedade ocidental

\begin{tabular}{|c|c|c|}
\hline CICLO & PERÍODO & CARACTERÍSTICAS \\
\hline $1^{\circ}$ & Séculos XVI e XVII & $\begin{array}{l}\text { Estado absolutista, capitalismo mercantil, declínio } \\
\text { da igreja e do corporativismo medieval, doutrina } \\
\text { do jusnaturalismo, o Estado passa a ser o único } \\
\text { legislador (reflexo das vontades do soberano). }\end{array}$ \\
\hline $2^{\circ}$ & $\begin{array}{l}\text { Revolução Francesa até } \\
\text { final das codificações do } \\
\text { século XIX }\end{array}$ & $\begin{array}{c}\text { Separação dos poderes, capitalismo } \\
\text { concorrencial/industrial, doutrina do } \\
\text { jusnaturalismo racional / iluminista e } \\
\text { contratualista, legalidade estatal burguês- } \\
\text { capitalista (reflexo do liberalismo econômico). }\end{array}$ \\
\hline $3^{\circ}$ & $\begin{array}{l}\text { Apogeu nos anos 1920-30 } \\
\text { durou até os anos 1960-70 }\end{array}$ & $\begin{array}{c}\text { Estado do Bem-Estar Social, capitalismo } \\
\text { monopolista (organizado), doutrina lógico- } \\
\text { formalista da dogmática normativa, Estado de } \\
\text { Direito (o Direito é o Estado e o Estado é o Direito } \\
\text { Positivo). }\end{array}$ \\
\hline $4^{\circ}$ & $\begin{array}{l}\text { A partir dos anos 1960-70. } \\
\text { Continua em vigor }\end{array}$ & $\begin{array}{l}\text { Crise do Estado do Bem-Estar, capitalismo } \\
\text { monopolista-financeiro (globalizado), persistência } \\
\text { da doutrina lógico-formalista e da dogmática } \\
\text { normativa sob a luz do neopositivismo, da política } \\
\text { dos Estados à política das empresas. }\end{array}$ \\
\hline
\end{tabular}

Fonte: Dados retirados de Wolkmer (2001). Obs.: Adicionamos um dado de Milton Santos (2008c) à última característica do $4^{\circ}$ ciclo (sublinhado). 2014.

O Estado moderno legisla e julga por meio de leis sistematizadas que formam o Direito Positivo tentando, a todo custo, não perder sua hegemonia (WOLKMER, 2001). No entanto, o modelo jurídico baseado no monismo entra em crise justamente por se apoiar em formas neopositivistas e por desprezar qualquer análise “[...] da prática política e das relações sociais, encastelou-se [...] em metodologias mecanicistas, assentadas em procedimentos lógico-linguísticos [...]" (WOLKMER, 2001, p. 59). Abre-se, assim, espaço para as práticas pluralistas nas últimas quatro décadas conduzindo a uma condição inédita da política dos Estados à política das empresas, vamos, portanto, abordar esse tema a seguir.

\subsubsection{A crise do monismo e a emergência do pluralismo jurídico}

A edificação do modelo monista do direito no Estado moderno do Ocidente que se iniciou, como foi visto, com o declínio do sistema feudal na Idade Média, foi tão bem estruturada em torno de uma dogmática jurídica ao longo desse período, que pensar em uma produção normativa fora do Estado atualmente parece não só estranho como também uma ideia completamente desprovida de sentido. Por isso, o esforço em 
resgatar a história da construção desse modelo jurídico da sociedade ocidental, ainda que não profundamente, favorece a análise de sua crise.

Como foi visto, o princípio da unicidade do sistema jurídico se encaixou perfeitamente com as necessidades da formação dos Estados nacionais, cada um com sua formação social particular. Contudo, assistimos atualmente a um dado nunca verificado na história humana e que segue causando um período de crise, sobretudo na unicidade jurídica dos Estados nacionais, esse novo dado é a unicidade técnica, cuja eficácia é dependente da mais-valia globalizada e da convergência dos momentos (SANTOS, 2008c).

O sistema técnico atual caracterizado pela informação permite que um conjunto de técnicas se comunique entre si assegurando que uma ocorrência em qualquer lugar seja conhecida instantaneamente em todo o planeta (convergência dos momentos) causando, inclusive, efeitos em vários locais, ainda que não de forma generalizada porque recebe o intermédio das grandes empresas, dessa maneira, Santos (2008c, p. 28) mostra como "[...] a história é comandada pelos grandes atores desse tempo real, que são ao mesmo tempo os donos da velocidade e os autores do discurso ideológico [...]". Surge, então, um conjunto de mundializações em função da unicidade técnica planetária, a saber: do produto, do dinheiro, do crédito e da informação, proporcionando a mais-valia mundial, tais mundializações são "[...] entretidas pelas empresas globais que se valem dos progressos científicos e técnicos [...]" (SANTOS, 2008c, p. 30).

Essas características do período atual, o fazem diferenciá-lo de qualquer outro período da história da humanidade. Cada novo período histórico é intercalado de um momento de crise, da qual sua superação revela um novo período, por exemplo, os ciclos do monismo jurídico colocados no quadro 1. Entretanto, como nos alerta Santos (2008c, p. 34), estamos num período que é ao mesmo tempo uma crise, vejamos:

[...] Como período, as suas variáveis características instalam-se em toda parte e a tudo influenciam, direta ou indiretamente. Daí a denominação de globalização. Como crise, as mesmas variáveis construtoras do sistema estão continuamente chocando-se e exigindo novas definições e novos arranjos.

O papel das empresas globais, em meio à crise instalada, é a de buscar o aumento da produtividade por meio de novas técnicas. Retomando o primeiro item deste capítulo, lembramos que os sistemas de objetos são indissociáveis do sistema de ações e 
que o uso de objetos técnicos demanda um ordenamento de normas formais ou não, portanto, o uso e a dependência cada vez maior das técnicas acarretam também a dependência cada vez maior de normas. Se o sistema de ações é centralizado às atividades hegemônicas, Santos (2008c, p. 36) argumenta que “[...] aumenta a inflexibilidade dos comportamentos, acarretando um mal-estar no corpo social [...]". Ainda em Santos (2008c), o discurso ideológico que legitima a globalização como necessária no atual período, além de impor uma perspectiva da crise sugere as maneiras de superação da mesma, querendo afastar unicamente a crise financeira, o que conduz ao agravamento desta, porque se trata de uma crise estrutural, que é não só econômica, mas também moral, política, social e do sistema jurídico predominante.

Consideramos, entretanto, que a mundialização financeira estabeleceu uma nova lógica determinada por dinâmicas próprias, de tal maneira a agravar o período de crise. Por meio do sistema técnico informacional, a partir de final da década de 1970 e começo de 1980, e, conforme argumenta François Chesnais (2005), por fim ao controle de entrada e saída do capital estrangeiro, ou seja, medidas de liberalização e desregulamentação sob a direção do Fundo Monetário Internacional (FMI), criou-se o espaço financeiro mundial e a integração de maneira imperfeita e hierarquizada dos sistemas financeiros nacionais.

Em consequência da integração em escala global, o jurista José Eduardo Faria (2011) sublinha alguns dilemas aos sistemas jurídicos nacionais; (a) a possibilidade de uma unificação global da legislação financeira; (b) o esgotamento da operacionalidade dos mecanismos jurídicos tradicionais diante dos agentes econômicos; (c) aumento da tensão entre democracia e capitalismo; (d) o agravamento das crises sociais. Em face da incerteza quanto ao futuro do direito, Faria (2011) criou alguns cenários possíveis sem a pretensão de sugerir previsões, mas, uma tentativa de orientar o debate acerca do processo de transformação por que passa a ciência jurídica, entre os cenários desenvolvidos, destacamos apenas um entre os dois considerados exequíveis pelo próprio jurista.

Este cenário diz respeito à globalização econômica e ao pluralismo jurídico, neste caso é considerada a expansão "[...] de regimes normativos que operam no âmbito de diferentes demarcações espaciais e funcionais, onde nenhum deles é dominante nem 
[...] incompatíveis com a ordem jurídica estatal [...]" (FARIA, 2011, p. 56) ${ }^{18}$. A expectativa dos agentes privados produtores das normas em escala planetária, conforme Faria (2011), é a busca por padronizações ${ }^{19}$, redução de custos e a supressão de barreiras administrativas em nome da produtividade das empresas e instituições financeiras, consolidando a característica apontada no último ciclo do quadro 1 exposto no item anterior, qual seja da política dos Estados à política das empresas.

Para Santos (2008c), as empresas globais responsáveis pela nova política não têm preocupações éticas, pois a existência de uma empresa é baseada na competitividade afastando qualquer ação altruísta. Ademais o Estado é levado a investir em infraestrutura para que o território se adapte às condições de fluidez e porosidade de que o mercado necessita em detrimento de investimentos sociais. Assim, a sociedade, sobretudo de baixa renda, não tem quem satisfaça suas necessidades em relação à moradia, saúde, educação, lazer e saneamento básico.

O agravamento da desigualdade social incitada pela crescente insatisfação das necessidades de sujeitos coletivos é marcado por espaços de conflitos que acabam por engendrar normatizações fora e até contra o Estado (WOLKMER, 2001; SANTOS, 1979).

Constata-se, por conseguinte, dois tipos de pluralismo jurídico, Wolkmer (2001) assim os classifica: a) pluralismo jurídico conservador com bases no capitalismo monopolista globalizado, comandado pelas grandes empresas; b) e o pluralismo jurídico progressista, denominado comunitário-participativo.

Essas duas formas de pluralismo jurídico, de acordo com Faria (2011), podem ser vistas como uma estratégia do Estado, que abre mão da responsabilidade regulatória, assumindo sua gradual perda de autoridade e ausência de efetividade diante das complexas relações do mercado internacional, e passa a criar meios para que agentes sociais e econômicos estabeleçam de maneira consensual o teor das normas, bem como (o Estado) passa a delegar atividades de execução.

A desjuridificação e a procedimentalização são dois processos verificados por Faria (2011) que vêm ocorrendo no sistema jurídico, (a) o primeiro trata da abdicação

\footnotetext{
${ }^{18} \mathrm{O}$ outro considera o fortalecimento dos blocos comerciais e do processo de regionalização sob o aumento da multissoberania, "[...] uma divisão horizontal e vertical de competências legislativas, de entrega voluntária de aspectos da soberania pelos países-membros [...]" (FARIA, 2011, p. 52), a exemplo da União Europeia.

${ }^{19}$ Tais padronizações internacionais, segundo Faria (2011, p. 58), preenchem as lacunas deixadas pela incapacidade técnica regulatória do Poder Público, ficando por conta "[...] dos chamados Standards Setting Bodies, como a International Organization for Standardisation (ISO) [...]” e outras.
} 
do poder regulatório em leis trabalhistas, alienação de empresas públicas, privatizações, entrega de responsabilidades ao terceiro setor, pelo Poder Público, (b) no segundo:

[...] Os Estados deixam de decidir o conteúdo das leis, limitando-se a estabelecer marcos ou procedimentos para que os diferentes setores sociais possam discutir e negociar as alternativas normativas mais adequadas aos seus respectivos interesses [...] Em vez de tomar decisões unilaterais e de impô-las imperativamente a cidadãos, empresas associações comunitárias e movimentos sociais, o legislador opta assim por uma criação negociada do Direito, com base na correlação de forças em vigor [...]. (FARIA, 2011, p. 64)

Fica claro que a criação negociada do direito, se não é unilateral, também não é exatamente um exemplo ideal de democracia já que tem como base a correlação de forças em vigor. Contudo, não deixa de ser um instrumento de fortalecimento da autonomia política e do controle social, que tem ocorrido, sobretudo, por meio de conselhos gestores. A intervenção urbanística estudada neste trabalho conta com a mediação de um Conselho com capacidade deliberativa, que será abordada no momento oportuno mais adiante.

Ainda que o dilema enfrentado pelo modelo dominante, o monismo jurídico, abarque toda a sociedade ocidental, o que mais nos interessa e que abordaremos em seguida, é o caso brasileiro.

\subsubsection{A cultura jurídica no Brasil}

As peculiaridades da formação social da América Latina e, especificamente, do Brasil nos permite conceber o presente tópico, considerando, ainda, o exposto no item 1.2.1, que a cultura jurídica como instância social é atrelada à história da formação social, econômica, política e territorial. Segue, desse modo, breve relato histórico.

Eduardo Galeano (2010) alerta que a divisão internacional do trabalho é fundamentada na lógica econômica em que uns países devem ganhar enquanto outros devem perder, no continente latino americano, todos os países se especializaram em perder desde os primeiros contatos com os europeus. O relato de Galeano (2010) consiste em dados históricos acerca do processo de expatriação de recursos naturais e de excedentes dos países latino-americanos encaminhados para alguns países europeus.

Destacando, todavia, as características da evolução brasileira, Caio Prado Jr. (1999, p. 34) diz que: 
[...] o Brasil figuraria como um território, em seguida como uma coletividade humana em vias de integração e afinal como um país e propriamente nação, de natureza marginal e periférica, destinada a servir de campo para o exercício e os objetivos daquela atividade mercantil característica do mundo moderno, dos povos europeus ou de origem europeia $[\ldots]$.

Nesse contexto, o sistema jurídico imposto no território brasileiro foi aquele adotado pelo colonizador, como explica Wolkmer (2001), tanto colonizadores como a aristocracia agrária (elite), partidária da filosofia liberal-individualista, menosprezaram os costumes jurídicos nativos e estabeleceram a cultura jurídica da metrópole, Portugal, baseada na lógica-formal.

Outrossim, a reprodução social no Brasil, como explica Csaba Déak (1991) no processo de independência fica atrelada à dominação de uma elite antes colonial diferente da burguesia que tem por princípios básicos a reprodução ampliada do capital por meio do assalariamento e de melhores condições sociais (educação, saúde, infraestrutura, mobilidade, etc.), enquanto a elite, ao expatriar o excedente do acumulado no mercado interno prejudicava a generalização da forma-mercadoria e a consequente reprodução ampliada do capital no país, como uma continuidade do processo colonial, promovendo, então, um processo de acumulação entravada.

Portanto, o império brasileiro manteve a tradição jurídica do período colonial, conforme Wolkmer (2001), mesmo com a criação, em 1827, das faculdades de direito em Olinda e em São Paulo, afinal, a estrutura Estatal não se modificara sendo baseada no Estado agrário e escravocrata. Contudo, embora o sistema jurídico fosse fundado naquele modelo europeu, no qual o Estado soberano e o único produtor de normas, houve paralelamente a ascensão do direito canônico, que iria, segundo Aldaíza Sposati (2001), regular a vida das pessoas (nascimento, morte e casamento), além de influenciar a produção normativa estatal e o comportamento público por meio da pressão moral dos costumes privados.

Mas, foi no advento da República que o monismo e o positivismo jurídico se consolidam, como afirma Wolkmer (2001), numa ordem liberal-burguesa, consagrando a democracia representativa e a separação dos poderes sob o federalismo presidencialista.

Prado Jr. (1999, p. 118-119) argumenta que embora houvesse modificações na estrutura social como a emancipação política, por exemplo, esta conservava seus traços coloniais tendo de um lado "[...] organizadores e administradores do negócio que aqui 
se instalara a fim de fornecer gêneros primários ao comércio internacional. No outro extremo, a grande massa de trabalhadores [...]", com a finalidade de garantir a produção para atender a demanda externa, privilegiando, por conseguinte, antes a produção do que o consumo da população, o que desfavorecia o mercado interno. Prado Jr. (1999) ressalta que ao visar um consumo especializado e restrito, a indústria brasileira se distribui e se estrutura de maneira "defeituosa" e desproporcionada afetando de maneira negativa a preparação tecnológica e a capacitação para o gerenciamento das atividades industriais. O que contribuiu largamente para o processo de acumulação entravada e a consolidação da elite nacional.

A elite agroexportadora e a nova classe industrial continuam detentoras do excedente produzido no Brasil enquanto a população, maioria pobre, segue sem os provimentos de suas necessidades básicas. Wolkmer (2001, p. 87), esclarece que neste cenário:

[...] o Direito Estatal vem regulamentar, através de suas codificações, os intentos dos proprietários de terras e da burguesia detentora do capital, ocultando, sob a transparência retórica liberal e do formalismo das preceituações procedimentais, uma sociedade de classe virulentamente estratificada [...].

E nesse processo vai se firmando a tradição do não-cidadão brasileiro, Santos (2007) usa essa expressão ao se referir, sobretudo, ao período do pós Segunda Guerra Mundial em que o governo brasileiro se subordina à política econômica da Aliança Norte e que conduz ao "milagre econômico". Sob o clima da Guerra Fria, novas diretrizes suprimem as liberdades civis com o argumento de se evitar a desordem social, em seguida o crescimento econômico (do mencionado "milagre") privilegia alguns setores produtivos agravando a desigualdade social.

Como consequência territorial, Santos (2007) ressalta as migrações. Esvazia-se regiões e se concentra populações em poucas cidades, originando megalópoles na região Sudeste e metrópoles nas demais regiões brasileiras. Em meio à formação dessas aglomerações, onde tudo tem um valor de troca e nas quais o consumo se torna prioridade, Santos (2007) destaca o esvaziamento da cidadania e a negação aos direitos essenciais aos pobres, como moradia e serviços sociais.

Em face da inconformidade e da busca pela realização de suas necessidades, que a população carente de cidadania se organiza e mesmo com a corporificação do direito estatal oficial cria novos padrões de direito. Entre os direitos oficial e não-oficial, 
Robert Weaver Shirley (1998 apud WOLKMER, 2001) ${ }^{20}$ distingui: a) as leis do Estado, ainda que formais, relacionadas com as leis da elite urbana; b) as leis dos coronéis, os latifundiários; c) e a lei popular, baseadas nos costumes de pequenos agricultores ou dos pobres nas áreas urbanas.

Diante da distinção relatada, somamos o argumento de Santos (2007, p. 104105) de que a busca pela cidadania não esgota a lei e a lei não esgota o direito positivo, produto "[...] de um equilíbrio de interesses e de poder. Daí ser legítima a procura por um novo equilíbrio, isto é, de um novo direito [...] assim o cidadão, a partir das conquistas obtidas, tem de permanecer alerta para garantir e ampliar sua cidadania [...]”.

Como exemplo de um novo direito criado fora do Estado, citamos uma pesquisa de Boaventura de Souza Santos (1979) realizada no interior de uma favela na cidade do Rio de Janeiro, cuja divulgação inauguraria o debate sobre o pluralismo jurídico no Brasil. Nesse estudo de sociologia sobre a retórica jurídica, Santos (1979) identifica uma produção jurídica que funciona de maneira autônoma, na qual o autor denomina como direito de Pasárgada, referindo-se ao nome fictício da favela que estudou, na qual o direito foi produzido em contraposição ao direito do asfalto, que seria o direito oficial como era chamado pelos moradores dessa favela ou o direito existente nas zonas urbanizadas.

O exemplo mencionado confirma uma das modalidades de pluralismo jurídico identificadas no item anterior, vale dizer, a modalidade progressista ou comunitárioparticipativo, distinto do pluralismo jurídico conservador controlado pelas grandes empresas globais. Os principais sujeitos coletivos produtores do ordenamento jurídico na modalidade progressista são os movimentos sociais, como revela Wolkmer (2001).

É exatamente o pluralismo jurídico comunitário-participativo que procuraremos demonstrar nesta pesquisa, considerando, ainda, a procedimentalização citada anteriormente, ou seja, a ação do Estado em estabelecer procedimentos para a produção normativa alternativa ou o direito negociado (FARIA, 2011), haja vista que o empreendimento proposto, objeto de nossa pesquisa, tem como princípios a participação de um Conselho na produção normativa, Conselho esse formado por pessoas da sociedade civil. Como veremos mais adiante, os conselheiros escolhidos fazem a mediação entre o Estado e os movimentos sociais.

\footnotetext{
${ }^{20}$ SHIRLEY, Robert Weaver. Antropologia jurídica. São Paulo: Saraiva, 1987.
} 
A possibilidade de participação da sociedade civil nesse tipo de política pública, no entanto, é algo recente, resultado de um conjunto de fatores, a) a procedimentalização como estratégia do Estado, b) pressões sociais na formulação de políticas urbanas, c) por força do processo de globalização do sistema capitalista. Desses aspectos resultaram as Parcerias-Público-Privadas (PPP).

\subsubsection{As Parcerias Público-Privadas}

O tema tratado neste item é demasiado abrangente, portanto, procuraremos apenas demonstrar como o modelo de Parceria Público-Privada (PPP), ligado a uma política de diminuição do aparelhamento do Estado, vai se legitimar a partir da década de 1990. É indispensável, entretanto, que comecemos por breves considerações sobre a dicotomia público/privado.

Verificamos em Norberto Bobbio (2011a), que a dicotomia público/privado tem origem na ciência jurídica e serviu de distinção entre o direito público e o direito privado, sobretudo com o advento do Estado moderno.

Bobbio (2011a, p. 21) afirma que "[...] Durante séculos [...] o direito privado foi direito por excelência [...] cujos institutos principais são a família, a propriedade, o contrato e os testamentos [...]", mas, com a formação do Estado moderno, o direito público é sistematizado em forma de lei em contraposição ao contrato do direito privado.

Ou seja, o direito público surge simultaneamente ao surgimento do absolutismo e do monismo jurídico. Entretanto, Bobbio (2011a) explica que o primado do público se manifesta, no século XX, como reação contra a doutrina do Estado liberal, "[...] doutrina do Estado limitado tanto com respeito aos poderes quanto às suas funções [...]" (BOBBIO, 2011b, p. 17), vale dizer, na ascensão do Estado do Bem-Estar Social.

O termo Bem-Estar Social, assegura Eric Hobsbawn (2004), só surgiu na década de 1940 para classificar a nova política econômica que os Estados nacionais assumiriam depois da Grande Depressão, a primeira grande crise do sistema capitalista que arrasaria as maiores economias do mundo.

Existe, por conseguinte, uma relação entre política e economia, Bobbio (2011a) atesta que a intervenção do Estado na economia é um processo de "publicização do privado", contudo, esse processo é acompanhado por outro inversamente proporcional: 
a "privatização do público". Sobre esses dois processos, Bobbio (2011a, p. 27) assim explica:

[...] Os dois processos, de publicização do privado e de privatização do público, não são de fato incompatíveis, e realmente compenetramse um ao outro. O primeiro reflete o processo de subordinação dos interesses do privado aos interesses da coletividade representada pelo Estado que invade e engloba progressivamente a sociedade civil; o segundo representa a revanche dos interesses privados através da formação dos grandes grupos que se servem dos aparatos públicos para o alcance dos próprios objetivos. [...].

Os dois processos mencionados, ainda que um tanto opostos, encontram razão de ser em função das vantagens do Estado de Bem-Estar Social, como a intervenção na economia e a geração de empregos, de um lado e as desvantagens por outro, como destaca Maria Sylvia Z. Di Pietro (2002, p. 24):

[...] a forma burocrática de organização, porque aplicada, indistintamente, a todas as atividades do Estado, mesmo as de natureza social e econômica, acabou por contribuir para a ineficiência do Estado na prestação dos serviços, ineficiência essa agravada pelo volume de atividades e pela crise financeira que tiveram que enfrentar especialmente os países da América Latina. (grifo do autor)

A consequência, como explica Di Pietro (2002), foi a transformação na concepção do Estado que continua sendo de Direito, protegendo as liberdades individuais, continua sendo Social, protetor do bem comum, e passa a ser também um Estado Democrático, subordina-se o Estado ao Direito e não a Lei, introduzindo a participação do cidadão nas decisões do governo.

Soma-se ao Estado Democrático de Direito a ideia de Subsidiário, princípio que, conforme Di Pietro (2002), implica em: a) limitação à intervenção estatal; b) ações de fomento, coordenação e fiscalização da iniciativa privada; c) parcerias entre o público e o privado.

Ações com a clara diminuição de tamanho do aparelhamento do Estado em pleno processo de privatização do público. No Brasil, esse processo começa a ocorrer com mais persistência na década de 1990, vamos a algumas evidências ${ }^{21}$ : i) A chamada Lei das Privatizações: Lei $n^{\circ} 8.031$, de 12/04/1990 (revogada mais tarde pela Lei $n^{\circ}$ 9.491, de 09/09/1997, dá diretrizes ao Programa de Desestatização); ii) Concessão de

\footnotetext{
${ }^{21}$ Di Pietro (2002)
} 
serviços públicos a empresas privadas, Leis $\mathrm{n}^{\circ}$ 8.987, de 13/02/1995 e $\mathrm{n}^{\circ} 9.074$, de 07/07/1995; iii) Autorização do serviço de telecomunicações, Lei $\mathrm{n}^{\circ} 9.472$ de 16/07/1997; iv) Franquia, Lei ${ }^{\circ} 8.955$ de 15/15/1995, ainda que essa lei nada mencione sobre a adoção de franquia na administração pública, a mesma tem fornecido diretrizes para sua utilização, o exemplo mais conhecido é a franquia da Empresa Brasileira de Correios e Telégrafos - ECT.

A PPP é associada às concessões de serviços públicos, mas, o termo ganha legitimidade por meio da Lei Federal $n^{\circ} 11.079$, de 30/12/2004, que institui normas gerais para licitação e contratação de pareceria público-privada no âmbito da administração pública municipal, estadual e federal.

A modalidade de PPP que nos interessa surge três anos antes da Lei n ${ }^{\circ} 11.079$, surge com o Estatuto da Cidade, Lei $n^{\circ} 10.257$, de 10/07/2001, conforme esclarecido no início do capítulo, trata-se das Operações Urbanas Consorciadas, levadas a efeito num quadro caracteristicamente neoliberal e de forte empreendedorismo urbano.

\subsection{Planejamento urbano sob o neoliberalismo e o empreendedorismo urbano}

A fim de reforçar e desenvolver a ideia da influência externa sob o viés da mundialização da economia na gestão das cidades, optamos por um recorte temporal conforme explanado a seguir.

A partir da recessão econômica da década de 1970, que provocou a transição do regime fordista-keynisiano de acumulação capitalista para um regime de acumulação flexível, que, conforme David Harvey (2005), marcado pelo desemprego, austeridade fiscal e tendência a privatizações, foi a base para a mudança do administrativo urbano para o empreendedorismo. Este empreendedorismo implica na parceria entre o Poder Público e a iniciativa privada ou comumente chamada de Parceria Público-Privada (PPP), processo sujeito a riscos dos quais o Poder Público assume grande parte, contudo, a expectativa é melhorar sua posição competitiva em relação à divisão espacial do consumo.

Claudete de Castro S. Vitte (2008) afirma que a aceleração do ritmo do consumo vem da necessidade do aumento do tempo de giro das mercadorias com a proposta de novos estilos de vida e de lazer, assim, os investimentos no meio urbano visam a criação de nova divisão espacial do consumo com a intenção de valorização do espaço urbano orientando a disposição de atrativos de consumo e entretenimento como shoppings centers, centros de convenções, parques, estádios, etc. 
A transformação pela qual passou o sistema capitalista deu origem à teoria da cidade global, que, na esteira da competitividade entre as cidades, tendo como pressupostos, segundo João Sette Whitaker Ferreira (2007), a terceira revolução industrial (informacional), o deslocamento das fábricas, os trabalhadores atuando em casa, o declínio dos centros industriais, os novos espaços especializados, os pontos nodais entre os fluxos globais, tem o sentido de consolidar a vocação terciária da cidade e tirar o máximo de proveito da globalização. Tal teoria, ainda segundo Ferreira (2007), alinhada com o discurso neoliberal é convergente também com o receituário para as cidades que queiram se enquadrar à classificação de cidade-global, o planejamento estratégico de cidades, que legitima o empreendedorismo urbano retro mencionado por Harvey.

Para Csaba Déak $(1991 ; 2001)$ os conceitos de neoliberalismo e de globalização no fim do século XX, acompanhados de outros neologismos, como pós-fordismo, pósmodernismo, sociedade em rede e outros, fazem parte de uma ideologia que tenta explicar uma nova fase (inevitável e benéfica) do capitalismo que levaria de fato ao desenvolvimento, mas que não passa de um discurso para legitimar políticas recessivas de privatizações. Para Déak e Shiffer (2007) a política neoliberal implantada no Brasil na década de 1990 causou mais desordem ao desmantelar a tentativa de uma abertura à social-democracia, provocando uma onda de privatizações, com destaque ao capital estrangeiro, além da valorização da moeda e incentivo ao consumo de importados, agravando a dívida externa.

Nas cidades, este processo foi acompanhado pelo desemprego e aumento da informalidade.

\subsubsection{Reestruturação urbana em face da reestruturação econômica}

Dentre os neologismos mencionados, no bojo do neoliberalismo a palavra de ordem para o planejamento urbano foi o "estratégico". Como lembra o urbanista e um dos entusiastas dessa modalidade de planejamento José Miguel F. Güell (1997) o planejamento estratégico de cidades partiu de conceitos extraídos das práticas empresariais, que por sua vez, basearam-se nas experiências militares. Por esse motivo, aqui no Brasil, alguns estudiosos sobre o assunto (VAINER, 2009; MARICATO, 2008; FERREIRA, 2007) têm feito duras críticas acusando o planejamento estratégico de representar os interesses do mercado em detrimento do conjunto dos cidadãos. Formou- 
se, portanto duas correntes opostas, uma a favor e outra contra o planejamento estratégico.

As justificativas para o uso do planejamento estratégico, segundo o sociólogo Manuel Castells e o urbanista Jordi Borja (1996), seriam a constituição de um grande projeto de cidade que pode representar um fortalecimento da democracia em função do consenso e do processo participativo e uma reação à crise econômica que deve atrair investimentos, elevar o número de empregos e transformar as bases produtivas da cidade.

Por causa da recessão dos anos 1970, Castells e Borja (1996) alegam que as cidades tiveram importante papel no combate às políticas neoliberais e à degradação ambiental se utilizando de projetos estratégicos com PPP. O que parece uma grande contradição, pois a diminuição do Estado por intermédio de parcerias com o capital privado representa o cerne da política neoliberal. As contradições continuam ao sugerirem que as cidades devem se adaptar às novas demandas da economia global e da competitividade internacional na tentativa de atrair os grandes eventos internacionais.

Os autores mencionados propõem ainda uma receita, mostrando o percurso desta modalidade de planejamento desde a Europa até a América Latina com a finalidade de aplicação do planejamento estratégico, os autores insistem nas palavras "reação" e "parceria público-privada" ou "reação conjunta" entre governo local e principais agentes econômicos, como se fosse de fato uma ação motivada ao combate das políticas neoliberais em busca da “[...] realização de uma transformação da infraestrutura urbana para facilitar a passagem do modelo industrial tradicional para o de centro terciário qualificado." (CASTELLS e BORJA, 1996, P. 155), ou seja, uma corrida para o moderno com a clara intenção de aumentar a produtividade, e apontam os cinco passos para a reação das cidades latino-americanas: i) a criação de condições para lideranças locais (prefeitos); ii) a mobilização de agentes econômicos estimulados pela abertura econômica; iii) a promoção de ações de caráter social-urbano buscando o equilíbrio social; iv) a ampliação da participação popular nas políticas urbanas; v) a promoção de uma identidade coletiva.

Esses autores acreditam que a falta de articulação entre os agentes urbanos, com a ausência de maior participação popular nos processos decisórios, está prestes a ser superada na América Latina e lembram que para alcançar o êxito "esta reação da cidade tende a se concentrar na definição de um Projeto de Futuro ou Plano Estratégico 
pactuado entre os principais atores públicos e privados." (CASTELLS e BORJA, 1996, p. 157), novamente enfatizando a "reação" da cidade e a PPP.

De outra forma e a despeito do que mencionou Güell sobre se deixar influenciar por práticas empresariais, Carlos Vainer (2009) argumenta que não é a primeira vez que o planejamento de cidades é influenciado pelos princípios de uma empresa, lembrando que o urbanismo modernista se baseou no ideal da fábrica taylorista, ou seja, na racionalidade e funcionalidade. $\mathrm{O}$ que se apreende é que da mesma forma que houve adaptações nos modos de produção capitalista, após os períodos de superacumulação, das quais as práticas empresariais foram as primeiras a incorporar, as cidades também tendem a se reorganizar e se reestruturar de modo a permitir a continuidade do processo de acumulação condizente com as novas características dos modos de produção.

Nesse sentido, Ermínia Maricato (2008) afirma que os planos estratégicos "vendidos" às municipalidades ${ }^{22}$ se ajustaram ao ideal neoliberal e serviram de complemento ao Consenso de Washington, receita de reestruturação produtiva para os países em desenvolvimento prevendo privatizações, desregulamentação, investimento direto estrangeiro, priorização de gastos públicos, enfim, ambos com a falsa aparência de propostas de processos democráticos, uma para os países e a outra para as cidades. Com a valorização da participação democrática, o planejamento estratégico disfarça os ideais neoliberais sendo adotado por governos progressistas como o Partido dos Trabalhadores (PT) em São Paulo na gestão da prefeita Marta Suplicy, como recorda Maricato, que faz a seguinte crítica: “[...] o convite à participação, nesse modelo, implica em subordinar os interesses de muitos aos interesses hegemônicos: unidade para salvar a cidade [...]" (p. 60, 2008), ou seja, salvar a cidade em favor dos interesses da minoria e em nome de uma identidade coletiva, o que ainda coloca em dúvida se o governo que o adota é, realmente, progressista.

Para que os interesses sejam assegurados, o planejamento estratégico propõe a PPP, que para Vainer (2009) se trata de uma maneira de trazer para o cenário o empresário capitalista e não o cidadão comum, ainda que este tenha interesses privados, a participar diretamente dos processos de planejamento e execução de políticas

\footnotetext{
22 A autora se refere à Conferência das Nações Unidas para os Assentamentos Humanos da ONU realizada em Istambul, 1996, na qual se destacou a importância das cidades no atual contexto de globalização econômica e no seu papel de combate à desigualdade social e ambiental tendo como instrumento o Planejamento Estratégico, segundo o modelo apresentado pelos urbanistas catalães e copiado por cidades da América Latina.
} 
chamadas de públicas, o que revela que "[...] o conjunto da cidade e do poder local que está sendo redefinido.” (2009, p. 89) ou ratificado.

Há, contudo, a contrapartida, se por um lado houve a influência do mercado imobiliário no sentido de incorporar a participação no processo de planejamento urbano, por outro lado, Maricato (2008), quando contextualiza a construção de uma política urbana socialmente mais justa, descreve que a atual politica urbana brasileira, também é fruto da pressão social.

A urbanista demonstra como as mobilizações sociais, a partir da década de 1970, por parte da população mais pobre resultou em ganhos significativos, entre eles citamos: a) A lei de parcelamento do solo, em 1979, que criminaliza o promotor de loteamentos ilegais; b) O Projeto de Lei (PL) do Desenvolvimento Urbano, 1983, que daria forte impulso na elaboração do Estatuto da Cidade em 2001; c) A criação do Ministério do Desenvolvimento Urbano (MDU), em 1985; d) A maior conquista da sociedade civil, segundo Maricato (2008), que seria a inserção dos artigos 182 e 183 na Constituição Federal de 1988, sobre a política urbana ${ }^{23}$; e) E, finalmente, em 1990, o Projeto de Lei (PL) visando regulamentar os artigos 182 e 183 da CF, que viria, após 11 anos, ser o Estatuto da Cidade, que regulamenta também a PPP.

Assim, não se pode afirmar que a política urbana brasileira atual resulta de um processo unilateral.

Em São Paulo, capital, a PPP de que trata a presente pesquisa tem ocorrido como uma política de desenvolvimento urbano com o instrumento que é a Operação Urbana Consorciada, tema que será aprofundado mais adiante e que é previsto na lei Municipal 13.430/2002, que dispõe sobre o Plano Diretor Estratégico (PDE) do município de São Paulo.

\footnotetext{
${ }^{23}$ Os artigos 182 e 183 da CF dispõem, respectivamente, sobre a obrigatoriedade da função social da propriedade urbana e sobre a usucapião, em favor do possuidor em detrimento do proprietário. Disponível em: <http://www.planalto.gov.br/ccivil_03/constituicao/constituicaocompilado.htm> Acesso em: 20 mai. 2014.
} 


\section{A OPERAÇÃO URBANA CONSORCIADA ÁGUA BRANCA}

Vigente por dezoito anos, a Lei $n^{\circ} 11.774 / 1995$ que criou a Operação Urbana Água Branca (OUAB) foi substituída em novembro de 2013. Como destacamos no capítulo anterior, com a finalidade de se adequar ao Estatuto da Cidade e ao PDE, a Lei $\mathrm{n}^{\circ} 15.893 / 2013$ foi sancionada após amplo debate com a sociedade civil.

Em 2007, a São Paulo Urbanismo apresentou o plano urbanístico da OUCAB à sociedade, por meio do Estudo de Impacto Ambiental (EIA), o qual foi analisado entre os técnicos do Poder Público municipal e os representantes da sociedade civil. A partir de então, várias sugestões foram incorporadas ao Projeto de Lei (PL) n 505/2012.

Durante o processo de construção da nova legislação houve reuniões técnicas com o Executivo, reuniões temáticas realizadas pela sociedade civil com a finalidade de qualificá-los para os debates e mais de uma dezena de audiências públicas, nas quais os anseios dos diversos setores da sociedade civil puderam ser registrados.

Neste capítulo iremos abordar os antecedentes da área em questão, os efeitos da OUAB durante os dezoito anos, identificaremos as outras Operações Urbanas implantadas na cidade de São Paulo e como ficam esses projetos urbanos diante da revisão do Plano Diretor da cidade.

\subsection{Barra Funda e a Operação Urbana Água Branca}

\subsubsection{Antecedentes da área}

O perímetro da OUCAB se insere completamente no distrito da Barra Funda, neste caso faremos um breve relato histórico da região, a fim de buscar entender porque um distrito próximo ao centro da cidade, dotado de certa infraestrutura urbana (serviços de energia elétrica, saneamento básico e transporte público) é um dos maiores vazios demográficos do município.

Em 1944, conforme Aldaísa Sposati (2001), houve a primeira divisão intraurbana na cidade de SP, na qual foi delimitado o subdistrito da Barra Funda, além de outras 37 subáreas (distritos e subdistritos) e em 1991, em nova divisão, a cidade passa a ter 96 distritos, acabando com a categoria subdistrito e por consequência com a diferença ou hierarquia que havia entre as áreas. 
Antes disso, a região, objeto deste estudo, já era formada pelos bairros da Barra Funda e da Água Branca. Sua vocação industrial se inicia no final do século XIX e começo do XX, segundo Aluísio Wellichan Ramos (2004), com a chegada de algumas fábricas, dentre as quais destacamos três das maiores: Cia. Antarctica Paulista em 1885, a Vidraria Santa Maria em 1896, a Indústrias Reunidas Francisco Matarazzo em 1920.

Para o período entre o final do século XIX e começo do XX, Rolnik (2003), apresenta o seguinte cenário para a cidade de SP: a) o Triângulo central (Rua São Bento, Rua Direita e Rua Quinze de Novembro), espaço comercial utilizado pela elite paulistana; b) os bairros residenciais, Campos Elísios, Higienópolis, Vila Buarque e região da Avenida Paulista, também espaço da elite paulistana; c) os bairros do subúrbio popular, antigas áreas rurais, constituídas por chácaras, que foram loteadas cedendo lugar às indústrias e casas populares, tendo por indutoras as estradas de ferro São Paulo Railway (Santos-Jundiaí) e Sorocabana, sendo a Água Branca, a Barra Funda, a Lapa, o Bom Retiro, o Brás, a Mooca e o Ipiranga.

Ramos (2004) ressalta que o processo de industrialização ocorrido na região abarcava diversos setores da indústria, porém com o predomínio da indústria de bens de consumo não duráveis, característico da fase de industrialização da cidade de SP. Simultaneamente ocorria um intenso processo de imigração na capital paulista, o que contribuiu com a formação dos bairros da Barra Funda e da Água Branca, marcadamente por imigrantes italianos, além da formação de um dos maiores núcleos de ex-escravos da cidade, como lembra Rolnik (2003, p. 76), que encontravam “[...] trabalho temporário como carregadores da estrada de ferro".

A ferrovia, por sua vez, localiza-se ao longo dos rios por ser uma área plana de fácil implantação, assim se evitava grandes obras como túneis ou pontes. A consequência disso para os bairros da Água Branca e da Barra Funda foi a diferença da ocupação ao norte e ao sul da estrada de ferro, que passou a ser um obstáculo entre essas áreas.

Ao norte da ferrovia, entre esta e o rio Tietê, confinou-se uma área com restrições à ocupação urbana em função das cheias periódicas do rio Tietê e dos córregos existentes na região, situação que levou à baixa densidade demográfica até o começo de século XXI. Ao sul da ferrovia, a ocupação foi mais intensa.

Conforme Ramos (2006), o desenvolvimento industrial nos bairros da Barra Funda e da Água Branca aconteceu no período de meados de 1880 até meados de 1950, 
período marcado por um sistema técnico correspondente, isto é, as fábricas e a ferrovia, depois disso se iniciou o processo inverso e simultaneamente a valorização imobiliária.

É importante ressaltar que essa desconcentração industrial não foi um processo exclusivo do distrito da Barra Funda, mas fruto de um processo de transformações que ocorreram em escala nacional, das quais Ramos (2006) assim destaca: a) a entrada de empresas internacionais em meados dos anos 1950; b) o deslocamento da indústria para o eixo rodoviário, sobretudo da indústria automobilística; c) e a partir dos anos 1980 a abertura aos produtos importados levando a indústria nacional a buscar novas tecnologias.

No caso do estado de São Paulo, Santos e Silveira (2008) afirmam que a modernização técnica, os novos dados normativos (incentivos fiscais) e interesses políticos marcam a intensificação da instalação de indústrias no interior. Foi verificada a seguinte mudança do número de estabelecimentos industriais (porcentagem em relação ao total no Brasil): década de 1970, Região Metropolitana 36,09\%, município de SP 28,94\% e interior 6,95; já na década de 1990, as participações eram respectivamente $21,95 \%, 9,23 \%$ e $15,26 \%$.

Na transição do século XX para o XXI, Ana Fani Carlos (2010) demonstra que o número de pessoas empregadas na indústria na capital paulista vem se reduzindo drasticamente desde a década de 1980, enquanto o número de pessoas empregadas no comércio e no setor de serviços, em maior medida e com destaque para o setor bancário e de telefonia, vem aumentando. Portanto, a indústria deixou de ser o maior atrativo populacional da cidade de SP há décadas.

A evasão de estabelecimentos industriais de SP no atual período é assim explicada por Carlos:

O deslocamento de estabelecimentos industriais de São Paulo ganha sentido no bojo de um processo de mundialização que muda o perfil da economia a partir de profundas transformações no setor produtivo, em função da queda das taxas de lucros que exige uma diminuição dos custos de produção; neste setor cabem os custos com a modernização da fábrica, os custos com o terreno (seja aluguel, IPTU), os impostos. (CARLOS, 2010, p. 54).

Diante do processo de mundialização, as cidades são alvos de novas estratégias urbanas com a intenção de torná-las competitivas, Mariana Fix (2001) argumenta que a promoção mundial das cidades passa a ser central na busca por investimentos 
estrangeiros e essa promoção implica em preparar certas áreas da cidade, preferencialmente aquelas dotadas de infraestrutura urbana, com a finalidade de transformá-las em novos polos de desenvolvimento, poder e riqueza mundiais, assim como foi discutido no item 1.3.

No caso de SP, estas áreas coincidem com os antigos bairros industriais, entre eles o distrito da Barra Funda.

Um dos legados da antiga ocupação industrial na Barra Funda foi a contaminação do solo. A PMSP, por meio do Decreto 42.319/2002, define área contaminada como o local:

[...] onde comprovadamente há poluição causada por quaisquer substâncias ou resíduos que nela tenham sido depositados, acumulados, armazenados, enterrados, ou infiltrados e que causa impacto negativo à saúde humana e ao meio ambiente. (SÃO PAULO, 2002)

O mapa 2, a seguir, apresenta a situação atual dos lotes contaminados na área da OUCAB. As áreas classificadas como potencialmente contaminadas ${ }^{24}$ são aquelas em que foram desenvolvidas atividades que, por suas características, podem ter contaminado o solo ou a água subterrânea, mas, que ainda não houve qualquer avaliação, isso só ocorrerá em caso solicitação de mudança de uso.

24 Manual de Gerenciamento de Áreas Contaminadas da CETESB. Disponível em: $<$ http://www.cetesb.sp.gov.br/areas-contaminadas/manual-de-gerenciamento-de-ACs/7-> Acesso em: 25 mai. 2013. 


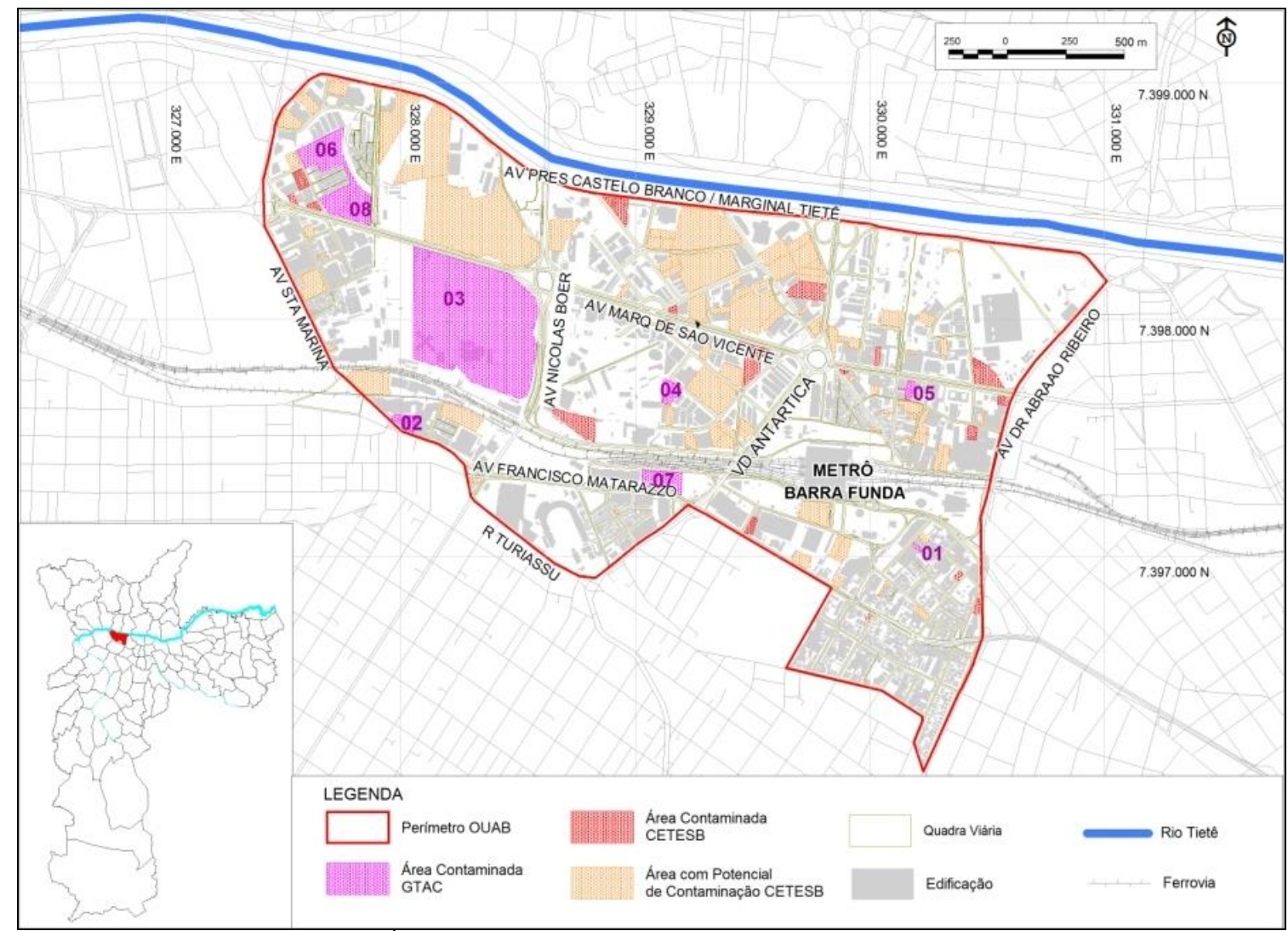

Mapa 2 - Áreas contaminadas (SVMA) dentro da OUCAB

Fonte: Elaboração própria a partir dos dados do Relatório de Áreas Contaminadas no Município de SP, 2012, da Relação de Áreas Contaminadas da CETESB, 2011 e do Mapa Digital da Cidade de SP (MDC). 2014.

As oito áreas numeradas são aquelas gerenciadas pela Prefeitura Municipal de São Paulo (PMSP) e que terão mudança de uso, passarão de industrial para residencial, as áreas gerenciadas pela Companhia de Tecnologia de Saneamento Ambiental (CETESB) são as que ainda são desenvolvidas atividades com potencial de contaminação.

$\mathrm{O}$ artigo $3^{\circ}$ do Decreto 42.319/2002, mencionado, estabelece que qualquer alteração de uso e ocupação do solo em áreas contaminadas ou suspeitas de contaminação, só será aprovada ou regularizada após avaliação de laudos técnicos submetidos ao Grupo Técnico Permanente das Áreas Contaminadas (GTAC), criado pela Secretaria do Verde e do Meio Ambiente (SVMA), pela Portaria $n^{\circ}$ 97/02, comprovando que os riscos provocados pelos contaminantes foram cessados.

A característica industrial do distrito da Barra Funda o levou a ser classificado como Zona Predominantemente Industrial no primeiro Plano de Desenvolvimento Integrado, Lei $\mathrm{n}^{\circ}$ 7.688/71, que abrange todo o município (SEMPLA, acesso em 2011), 
mas, conforme relatado, as transformações ocorridas no setor produtivo pelo processo de mundialização da economia, levaram o Poder Público a uma reestruturação no distrito.

Conforme aponta Luiz Guilherme R. de Castro (2006), em 1991 foi publicado um Projeto de Lei para a OUAB, na gestão de Luiza Erundina (1989-1992), com objetivos de adensar a área com habitação e expandir o setor terciário da economia aumentando a oferta de empregos, aproveitando a acessibilidade proporcionada pela estação terminal e intermodal Palmeiras - Barra Funda.

Entretanto, foi só na gestão seguinte (prefeito Paulo Maluf) que o Projeto de Lei foi aprovado com um estoque de $900.000 \mathrm{~m}^{2}$ de área para construção de imóveis não residenciais e apenas $300.000 \mathrm{~m}^{2}$ de área reservada para uso residencial, desde então o estoque de uso residencial chegou ao final e o de uso não residencial foi pouco procurado, demonstrando que o uso do território não correspondeu à norma jurídica.

O perímetro da OUAB se insere no Plano Regional Estratégico (PRE) da Subprefeitura da Lapa, há a predominância de Zona Mista $(\mathrm{ZM})$ para esta região, mapa 03. Esse zoneamento permite a implantação de usos residenciais e não residenciais considerando, ainda, o mesmo lote ou edificação (SÃO PAULO, 2004), respeitando "critérios gerais" de compatibilidade de incômodo, como, por exemplo, ruído ou odor e estabelece também o coeficiente de aproveitamento construtivo, o que equivale ao tamanho da edificação em área e altura, inclusive o subsolo de um lote.

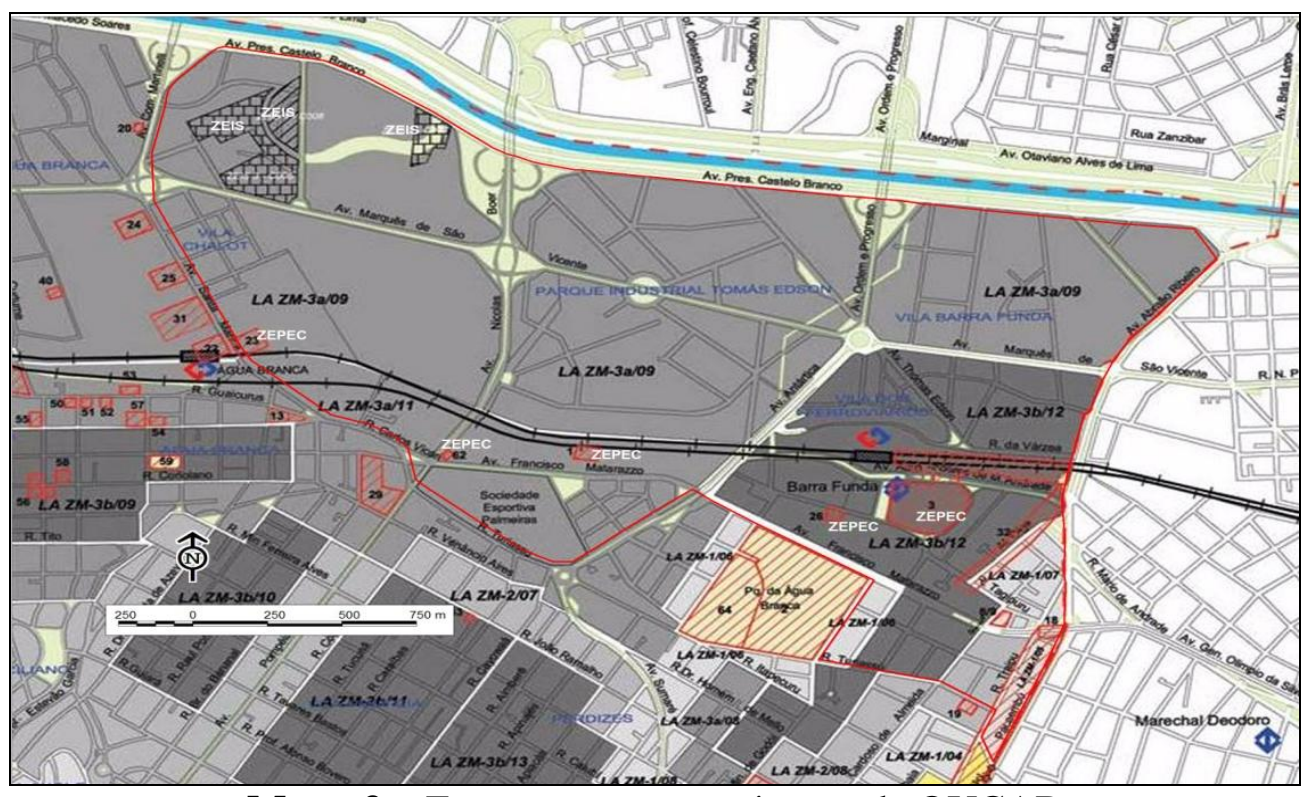

Mapa 3 - Zoneamento no perímetro da OUCAB

Fonte: Adaptado (em 2014) do mapa 4 do Plano Regional Estratégico da Subprefeitura da Lapa, 2004. 
Há ainda alguns lotes classificados como Zona Especial de Preservação Cultural (ZEPEC) destinados à preservação dado ao valor histórico dos imóveis e terrenos enquadrados como Zona Especial de Interesse Social (ZEIS), destinados à regularização fundiária e a produção de moradia para população de baixa renda, além da provisão de equipamentos sociais e culturais.

Na gestão do prefeito Paulo Maluf (1993-1996) foi estabelecido o programa de intervenções urbanas, abertura de ruas, implantação de equipamentos coletivos, de áreas verdes, de obras de drenagem e outras edificações, a serem realizados por empreendedores interessados e que atenderem aos pré-requisitos estipulados em edital. Entretanto, diante da criação das novas Leis, o Estatuto da Cidade (2001), federal, e o PDE (2002), municipal, a lei que cria a OUAB passa por uma revisão a fim de adequações com a Lei Federal, transformando-se em uma Operação Urbana Consorciada.

Ademais, o que dificulta a ocupação por moradia é o histórico de enchentes na região, embora tenha sido feita a canalização dos três córregos (Água Branca, Água Preta e Sumaré) no interior do perímetro da OUAB, contribuindo para o desenvolvimento da ocupação, as cheias persistem e é uma das principais reclamações dos moradores da região, em um blog criado por eles a fim de discutir a intervenção urbanística e problemas do distrito, é possível encontrar denúncias como esta:

[...] O rio Tietê transborda e as águas voltam pelos córregos e galerias, enchendo as ruas e casas, mesmo que a chuva já tenha deixado de cair. As galerias são antigas, os córregos estão assoreados e cheios de lixo, as várzeas estão ocupadas e impermeabilizadas. [...] (MOVIMENTO ÁGUA BRANCA, 2011, grifo do autor). 
A seguir, o mapa 4 apresenta a localização dos córregos e galerias.

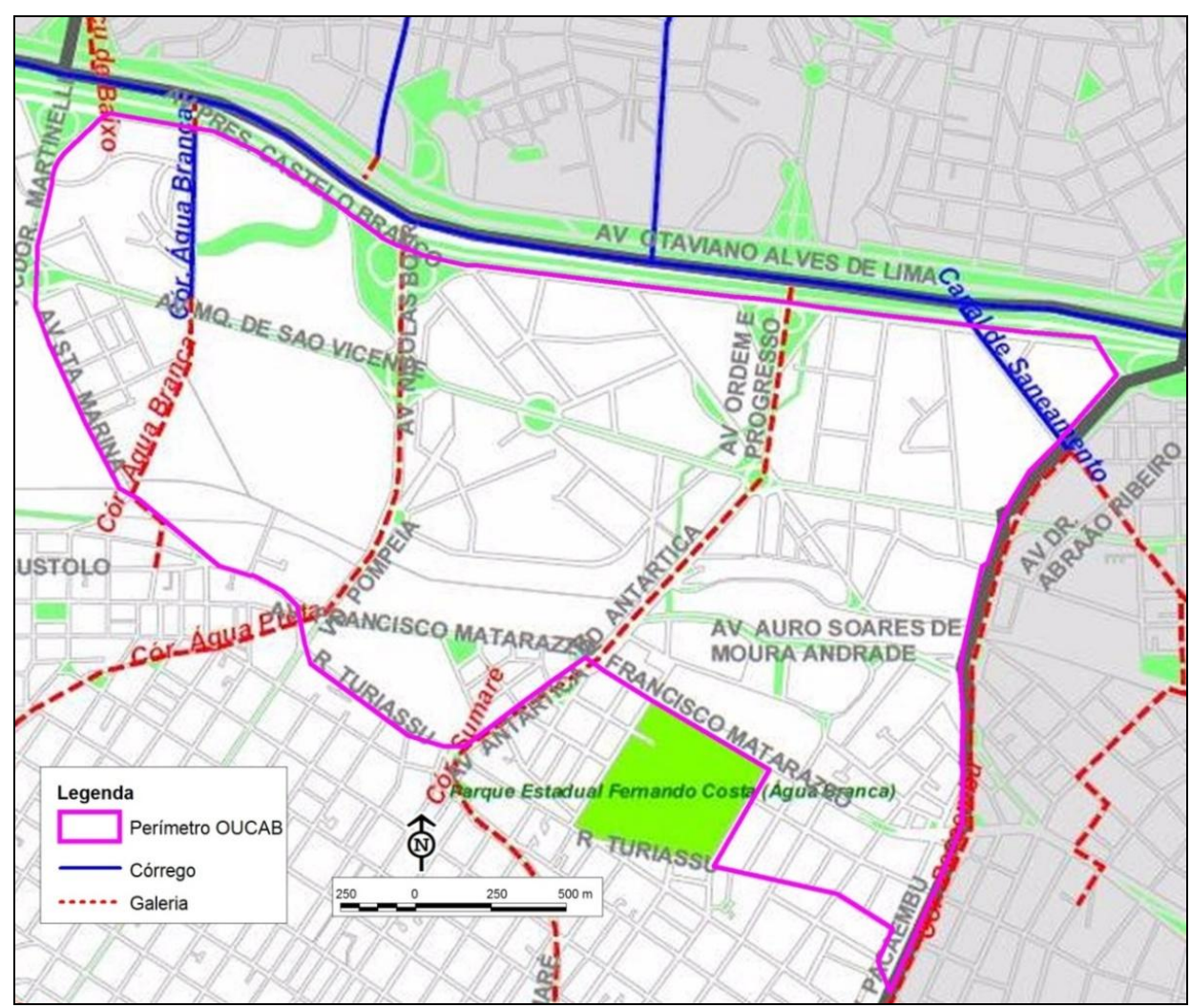

Mapa 04 - Drenagem: Córregos e galerias no interior da OUCAB.

Fonte: Adaptado (2014) do mapa de drenagem da Subprefeitura da Lapa. Acervo Secretaria do verde e Meio Ambiente (SVMA).

Este é o cenário que levou o Poder Público municipal a planejar a intervenção urbanística proposta, problemas de alagamentos, histórico de áreas contaminadas e grandes glebas vazias em uma área servida de infraestrutura urbana.

Entretanto, se a intervenção é necessária e se se trata de uma PPP, como atrair o interesse do capital privado em uma área com o histórico mencionado no parágrafo anterior? Para Fix (2001), Maricato e Ferreira (2002) a falta de atrativo para o capital imobiliário foi o motivo da OUAB não ter "decolado", considerando o tempo decorrido (desde 1995). Enquanto isso o Estado é obrigado a investir antecipadamente em melhorias ou em algum projeto motor, a chamada âncora, para atrair a iniciativa privada.

\subsubsection{A OUCAB e sua "âncora cultural"}

Segundo o resumo apresentado pela PMSP sobre a movimentação financeira, elaborado em dezembro de 2011, já houve a entrada por meio da outorga onerosa o valor de aproximadamente 120 milhões de reais, que somado à receita financeira líquida soma pouco mais de 150 milhões de reais, deste valor foram gastos com obras, 
desapropriações, taxa de administração e despesas bancárias aproximadamente 17 milhões de reais sobrando o saldo de quase 135 milhões de reais.

Apesar de dinheiro em caixa, a urbanista Raquel Rolnik denunciava em seu blog $^{25}$, em novembro de 2011, que nenhuma obra de drenagem tinha sido feita no local até então, destacando, ainda, a presença de Zona de Interesse Social (ZEIS), área destinada à construção de moradia para a população de baixa renda, e que também nada tinha sido feito até então.

Haja vista os valores arrecadados e a falta de implantação de infraestrutura necessária e urgente ${ }^{26}$, a prefeitura anuncia um grande projeto urbano, que busca resgatar a identidade coletiva, de forte apelo popular, com a construção da "Fábrica dos Sonhos", similar à Cidade do Samba no Rio de Janeiro, na figura 03, adiante, é possível ter uma ideia da distância entre o sambódromo e a Fábrica dos Sonhos, que se situa na convergência da Marginal Tietê e a Av. Abraão Ribeiro.

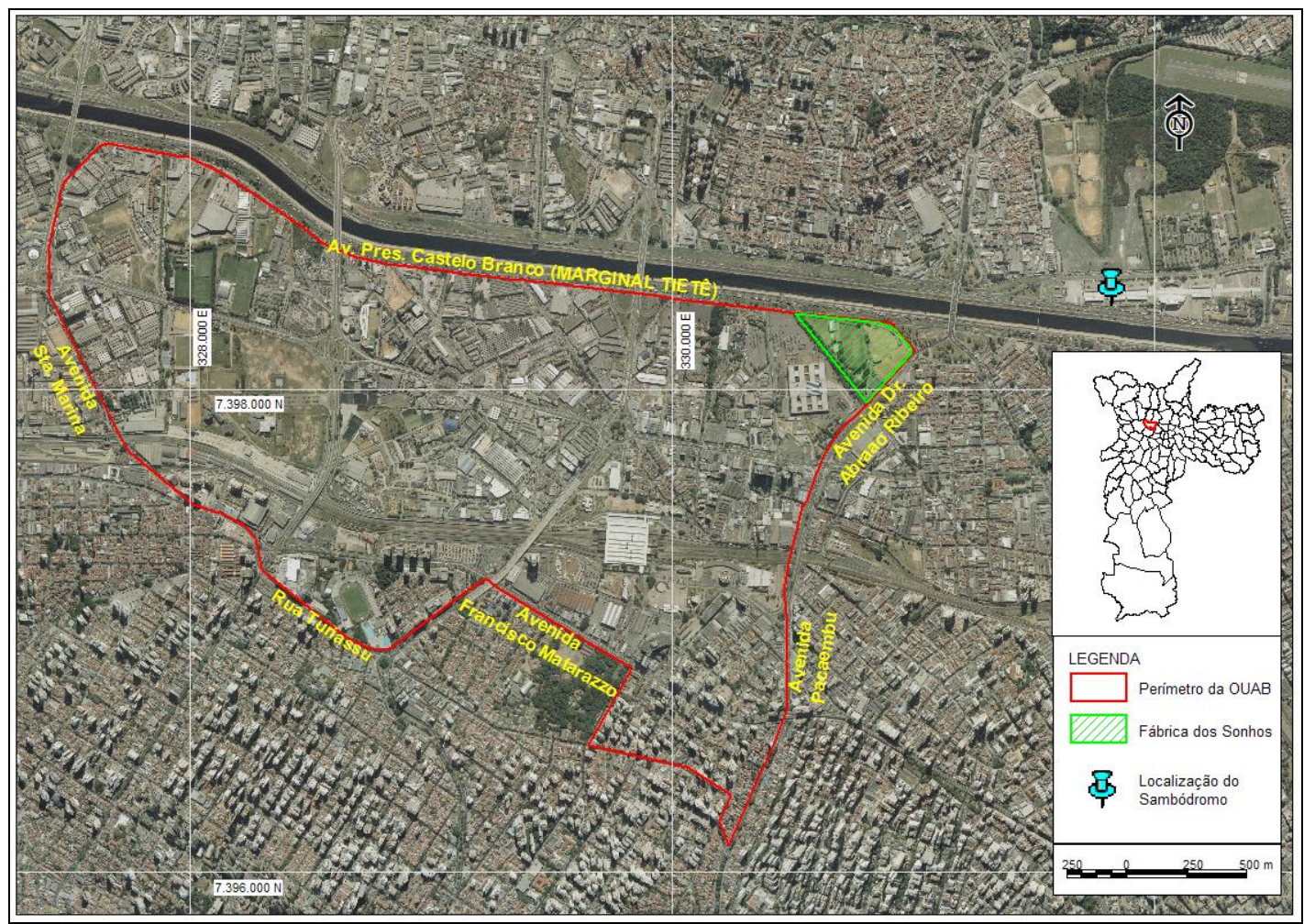

Figura 3 - Perímetro da OUAB e da Fábrica dos Sonhos. Fonte: Elaboração própria ${ }^{27}, 2014$.

25 Disponível em: http://raquelrolnik.wordpress.com/2011/11/03/operacao-agua-brancabarra-fundaprefeitura-anuncia-noticia-requentada. Acesso em: 20 nov. 2011.

${ }^{26}$ Reportagem da Folha de São Paulo em fevereiro de 2011 mostra os estragos, prejuízos e a paralisação de trens na estação Barra Funda da CPTM por causa do alagamento provocado após chuva intensa. Disponível em: http://www1.folha.uol.com.br/cotidiano/881841-circulacao-de-trens-na-lapa-e-na-barrafunda-e-interrompida.shtml. Acesso em: 21 out. 2011.

${ }^{27}$ A imagem foi elaborada utilizando o programa de SIG Mapinfo (Professional version 9.5; Mapinfo Corporation, New York, NY, USA). Ortofoto Emplasa, 2007; perímetro da OUAB e da Fábrica dos Sonhos do a partir do Estudo de Viabilidade Ambiental (EVA) emitido pelo Consórcio Schahin 
Inspirada na Cidade do Samba, o projeto visa ao fornecimento de estrutura aos catorze barracões das Escolas de Samba do Grupo Especial numa área de $83.559 \mathrm{~m}^{2}$, na qual serão realizados os trabalhos de produção dos carros alegóricos, fantasias e adereços, além de novo ponto turístico, assim como a Cidade do Samba que surgiu a partir de projetos semelhantes no Caribe para receber os turistas em viagens de cruzeiros $^{28}$, denotando que a necessidade era a priori comercial e o atendimento aos anseios das comunidades das Escolas de Samba.

Contudo, o Estudo de Viabilidade Ambiental (EVA) apresentado à Secretaria do Verde e Meio Ambiente (SVMA) destaca que hoje os barracões estão espalhados pela cidade fazendo com que o percurso dos carros alegóricos até o Sambódromo envolva um esforço da Companhia de Engenharia de Tráfego visando minimizar os impactos dos deslocamentos. Além disso, algumas Escolas de Samba ocupam irregularmente áreas públicas e em condições insalubres para os trabalhadores, sendo que o projeto Fábrica dos Sonhos é comemorado pelas comunidades das Escolas de Samba.

A obra deve ser financiada pelo Tesouro Municipal de SP e o valor estimado é de aproximadamente 125 milhões de reais, o órgão responsável pelo empreendimento é a São Paulo Obras (SPObras), empresa municipal vinculada à Secretaria de Infraestrutura Urbana (SIURB).

O EVA revela que não haverá desapropriação no local, contudo, não há esforço em demonstrar que não há outra área possível para o empreendimento, considerando que o local proposto é propício a alagamentos nos períodos chuvosos.

Com o fluxo de trabalhadores que circularão após a conclusão do empreendimento, se espera induzir a abertura de estabelecimentos comerciais no setor de alimentos e serviços, aquecendo a economia local. O novo polo turístico somado às melhorias esperadas em função da OUCAB poderá valorizar as adjacências atraindo o capital imobiliário tão esperado para a efetivação da Operação Urbana.

Entretanto, em que pese os impactos positivos, a área atual do empreendimento diminuirá a taxa de permeabilidade de $80,07 \%$ para $53,49 \%$, número significativo tendo em vista os danos historicamente conhecidos provocados pelas enchentes.

Passarelli, disponível em: http://www.prefeitura.sp.gov.br/cidade/secretarias/upload/meio_ambiente/ arquivos/eva_fabrica_dos\%20_sonhos/web.pdf . Acesso em: 20 dez. 2011. Altura: 1123 pixels. Largura: 794 pixels. 96 dpi. $151 \mathrm{~Kb}$. Formato JPEG.

${ }^{28}$ Ver. <http://cidadedosambarj.globo.com> 
Além da Fábrica dos Sonhos, outros projetos de grande porte vêm sendo implantados dentro do perímetro da OUCAB, entre eles destacamos: a) o Bourbon Shopping Pompeia, foto 01 ; b) a reforma do estádio da Sociedade Esportiva Palmeiras, foto 02; c) ampliação do Shopping West Plaza; e d) o Centro Empresarial Água Branca $(\mathrm{CEAB})$, foto 03, esses empreendimentos não foram levados em conta no Estudo de Impacto Ambiental da OUCAB, apesar dos impactos causados como, por exemplo, aumento do número de veículos nas vias locais e incômodo de ruído.

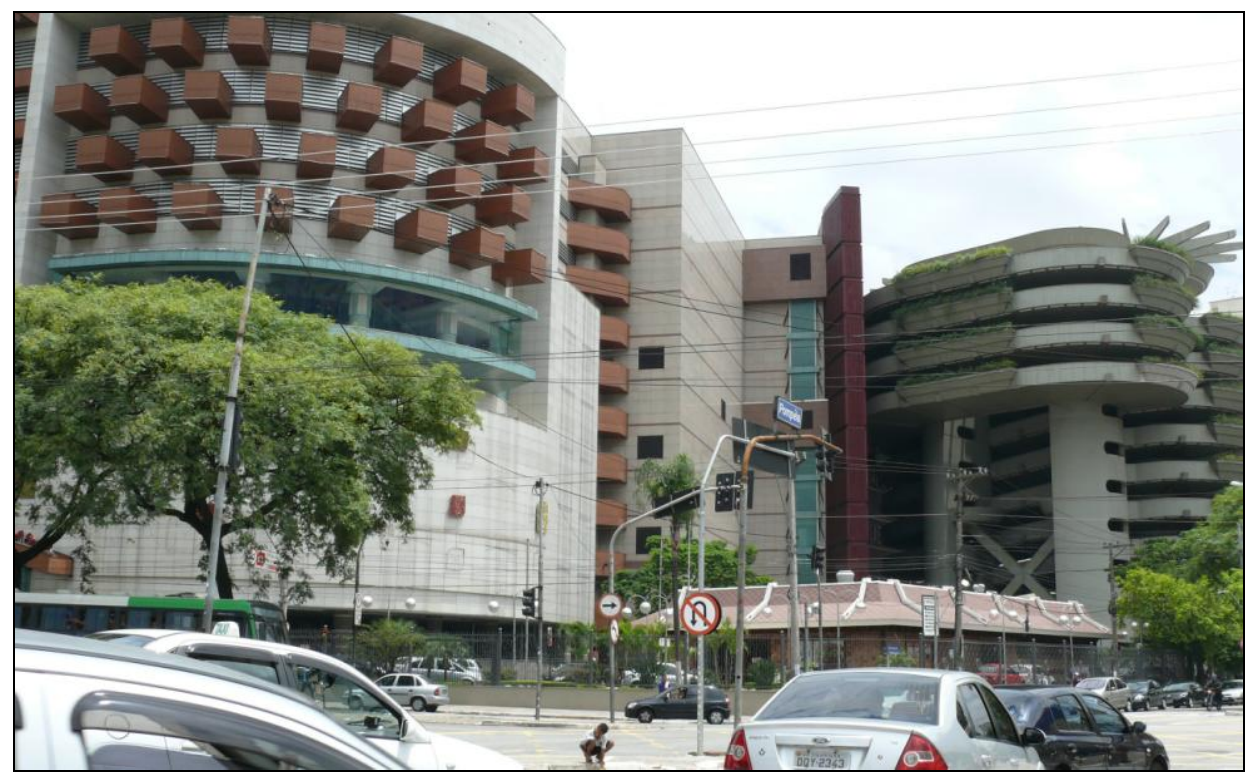

Foto 1: Vista parcial do Shopping Bourbon, esquina da Avenida Francisco Matarazzo com a Avenida Pompéia. Fonte: Suzana Cardoso, 2013.

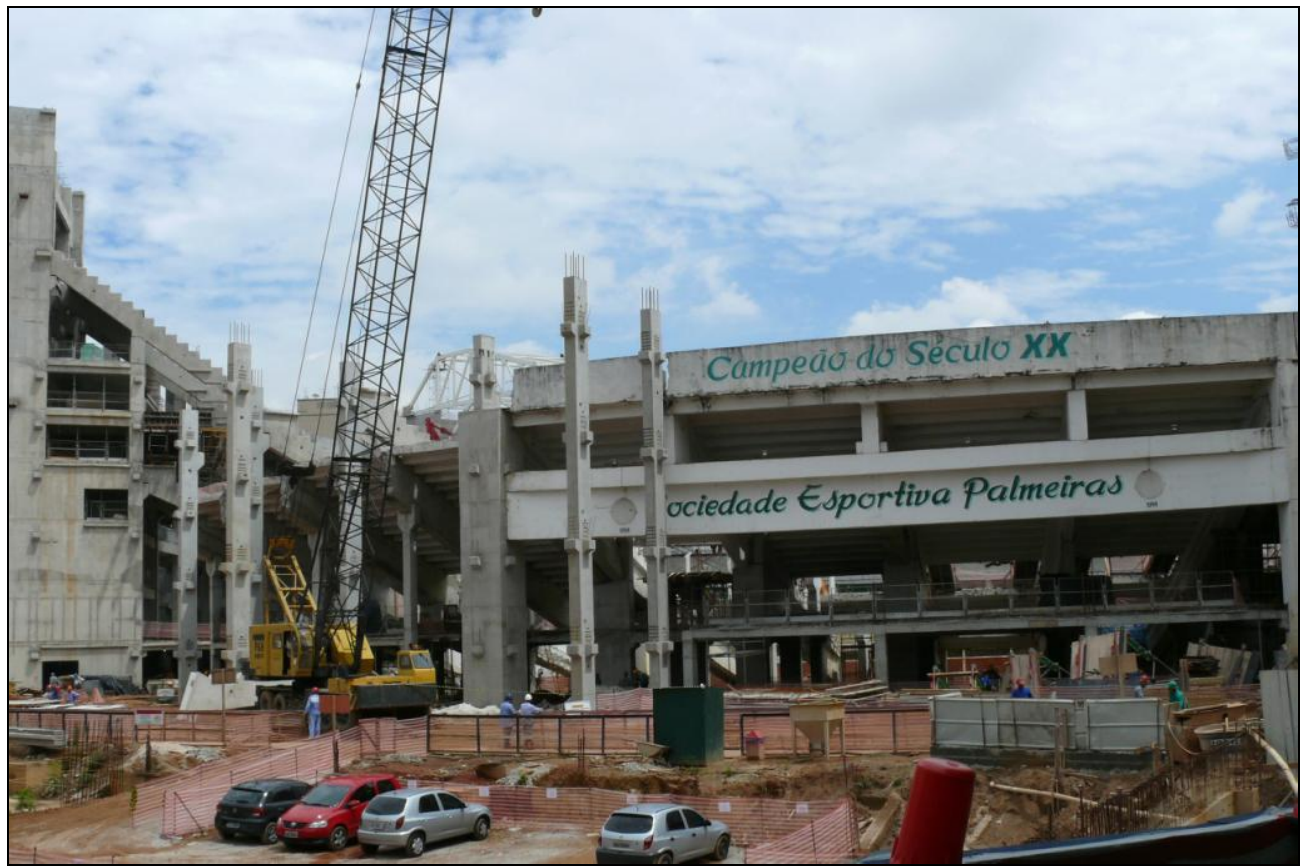

Foto 2: Vista parcial da Arena Palmeiras em reforma. Fonte: Suzana Cardoso, 2013. 


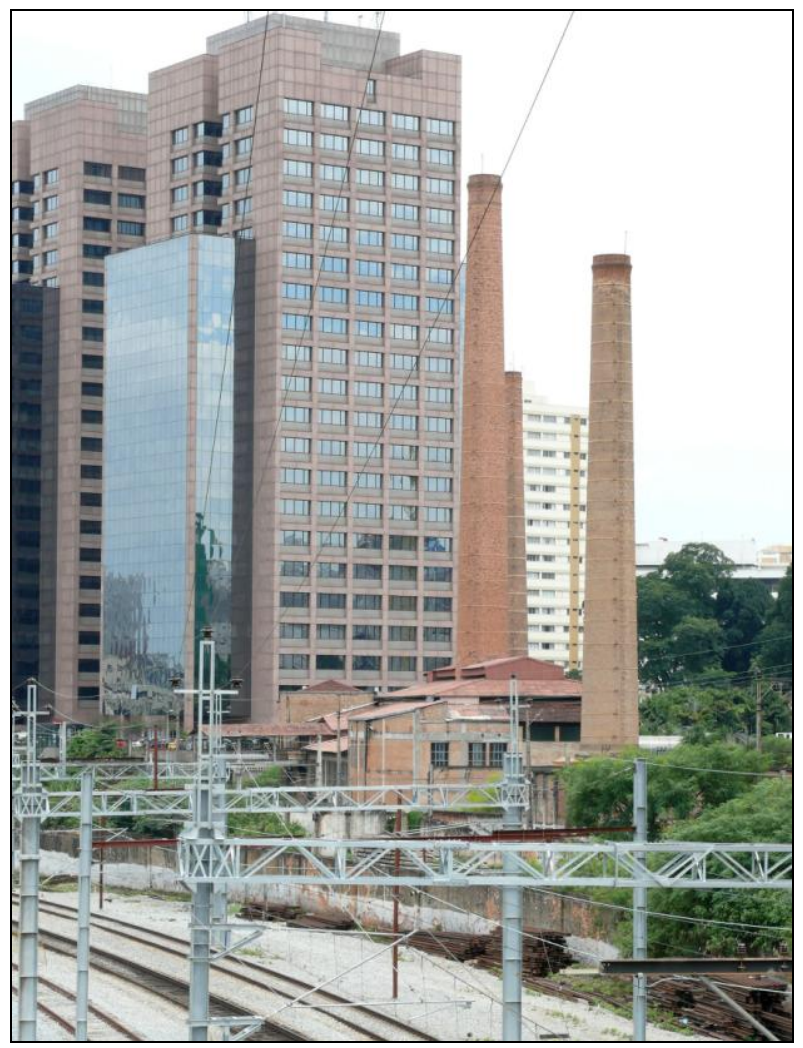

Foto 3: Vista parcial do CEAB ao lado da Casa das Caldeiras (antiga indústria da família Matarazzo) e no primeiro plano, parte da ferrovia. Fonte: Suzana Cardoso, 2013.

Os quatro empreendimentos mencionados têm em comum o fato de se localizarem na Avenida Francisco Matarazzo e representarem, conforme Ramos (2006), o processo de desindustrialização e de estímulo à valorização imobiliária com tendência à verticalização como o empreendimento observado na foto a seguir.

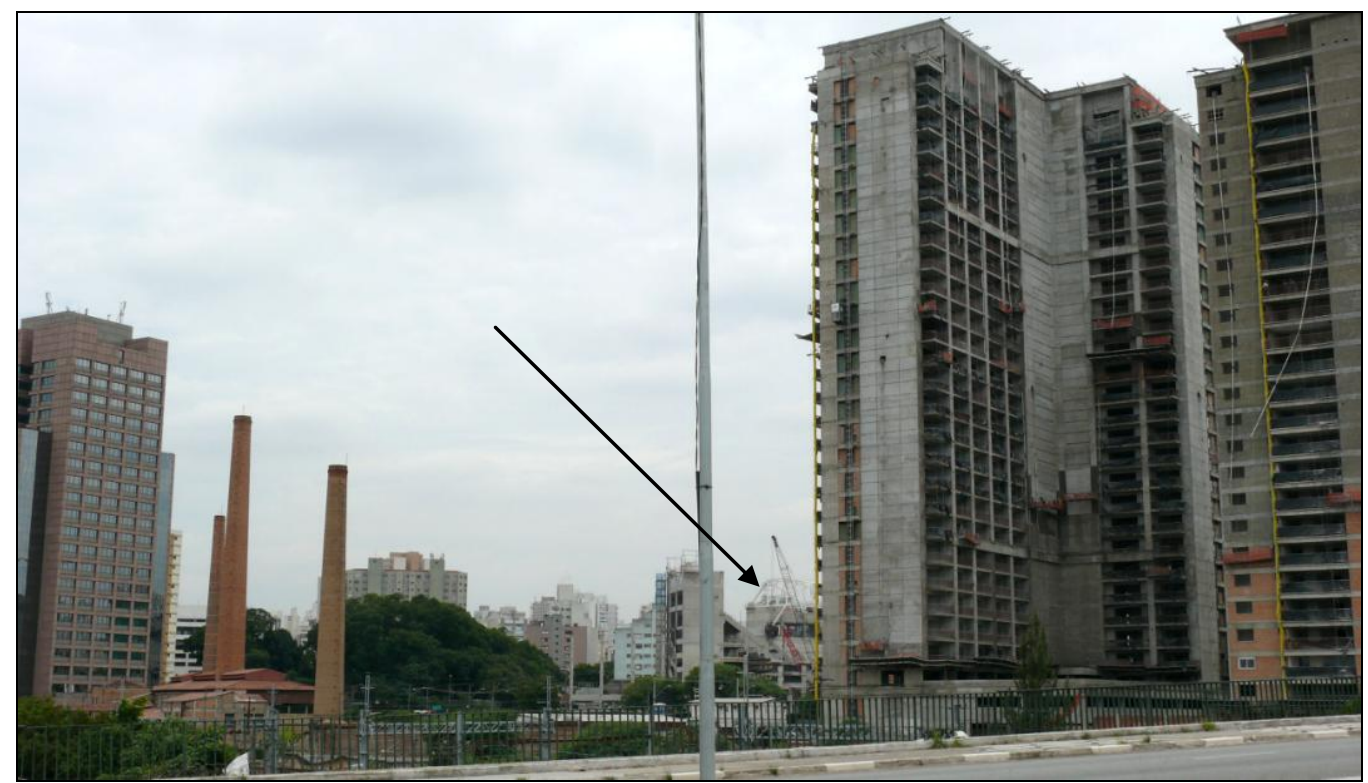

Foto 4: A esquerda um edifício da CEAB e a Casa das caldeiras com suas três chaminés, à direita, empreendimento residencial em construção e no destaque (seta) ao centro, Arena Palmeiras em reforma. Fonte: Suzana Cardoso, 2013. 
Diante deste cenário, o processo de valorização imobiliária se instalou na região. Esta, entre as situações que marcaram as outras Operações Urbanas implantadas na capital paulista, fez com que este instrumento de intervenção urbanística fosse criticado por vários especialistas geógrafos e urbanistas ${ }^{29}$, por beneficiar o mercado imobiliário em detrimento da população de baixa renda, que muitas vezes é obrigada a deixar o local para morar cada vez mais na periferia da cidade. João S. W. Ferreira (2010) chama esta forma de gestão e de planejamento da cidade de "urbanismo de mercado".

O "urbanismo de mercado" surge como salvação da crise fiscal ao inserir o capital privado nas intervenções de política pública urbana por meio da parceria público-privada. Ao entrar na lógica do mercado, o lucro passa a ser o fundamento de uma política que tem por princípios a justiça social, respeito à função social da propriedade e transferência para a coletividade de parte da valorização imobiliária, entre outros, conforme PDE (Lei 13.430, 2002).

Entretanto, na prática isso não tem sido verdadeiro. Ferreira (2010) denuncia justamente o oposto, entre alguns exemplos ele chama a atenção para um terreno que pertenceu à Telesp e que, durante o processo de privatização, passou para a Telefônica e foi mantido vazio desde então, este terreno corresponde à área 03 do mapa 2.

Uma área de duzentos e cinquenta mil metros quadrados estimado em 100 milhões de reais em 2005 foi vendida em 2007 por cerca de 125 milhões de reais, ou seja, uma valorização de $25 \%$ em dois anos, segundo Ferreira (2010), por causa da possibilidade de se criar um "bairro novo", na "degradada" área da Barra Funda. A respeito deste terreno, Ferreira lembra que:

[...] na ótica de um governo progressista e comprometido com as mudanças sugeridas pelo Estatuto da Cidade, uma área como essa, vazia há anos à espera de valorização, deveria ser combatida pelo mau uso e destinada à habitação de interesse social [...] (FERREIRA, 2010, p. 210).

\footnotetext{
${ }^{29}$ Ana Fani A. Carlos. São Paulo: do capital industrial ao capital financeiro. In Geografias de São Paulo (São Paulo. Ed. Contexto, 2004); Isabel A. P. Alvarez. A reprodução da metrópole: o Projeto Eixo Tamanduatehy, tese de doutoramento, Departamento de Geografia, Faculdade de Filosofia, Letras e Ciências Humanas, USP, São Paulo, 2009; Otília Arantes; Ermínia Maricato e Carlos Vainer. $O$ pensamento único das cidades (Petrópolis, Vozes, 2000); Mariana Fix. Parceiros da exclusão (São Paulo, Boitempo, 2001).
} 
Em artigo jornalístico constante no sítio eletrônico da empresa compradora do terreno mencionado, a Tecnisa ${ }^{30}$, é noticiado que o terreno, que foi adquirido por 125 milhões, já está orçado em 700 milhões de reais, uma supervalorização, e que o projeto do empreendimento chamado de "Jardim das Perdizes", anexo A, prevê trinta torres de apartamentos de área entre $90 \mathrm{~m}^{2}$ a $270 \mathrm{~m}^{2}$ e informa ainda, que o $\mathrm{m}^{2}$ do apartamento novo na região está avaliado em 6 mil reais, vale dizer que um apartamento de $90 \mathrm{~m}^{2}$ poderá custar 540 mil reais.

Trata-se de um terreno originalmente público que se transformou em oportunidade de fonte de renda no mercado imobiliário, contrariando os princípios de justiça social preconizados no PDE do município de SP e no Estatuto da Cidade. Este caso demonstra os resultados de uma política alinhada ao ideário neoliberal adotada pelo Poder Público municipal.

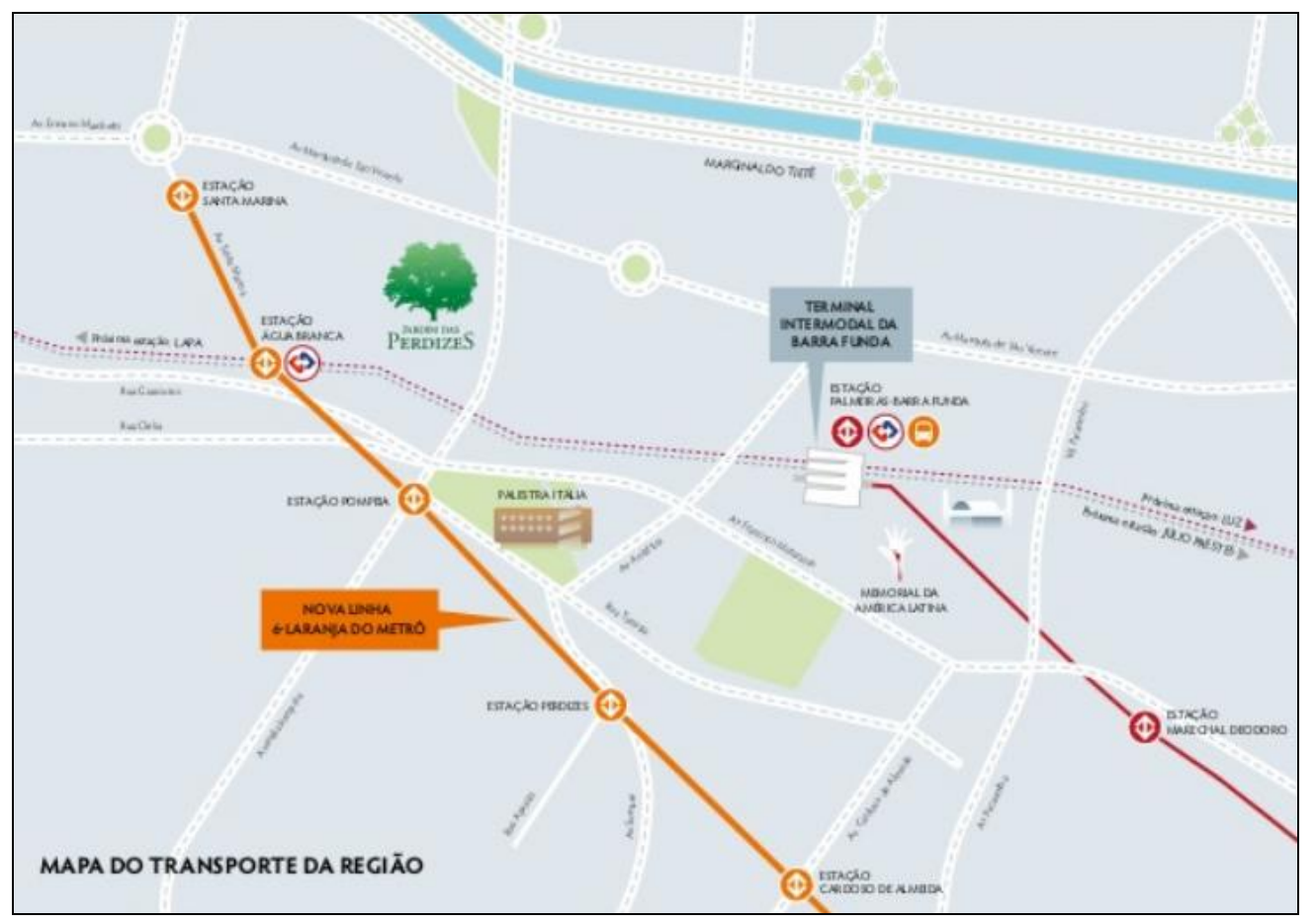

Figura 4: Localização do empreendimento Jardim das Perdizes. Croqui sem escala e sem norte. Fonte: Revista Viver São Paulo, editora Contadino, 2013. ${ }^{31}$

A verticalização em processo verificada na região da OUCAB conta com a implantação de grandes projetos urbanos para que a consequente valorização dos imóveis no distrito da Barra funda contribuam com as vendas.

\footnotetext{
30 Artigo originalmente publicado no jornal Folha de São Paulo de autoria de Carolina Matos em 31/07/2011 e com texto integral no site: < http://www.tecnisa.com.br.>

31 Revista publicitária voltada ao mercado imobiliário. Disponível em: < http://www.jardimdasperdizes.com.br/midia/revista\#page/2> Acesso em mar de 2013.
} 
Observamos o uso da "âncora cultural", nos anúncios do empreendimento "Jardim das Perdizes", em edição especial da Revista "Viver São Paulo", editora Contadino, da qual mencionamos na figura acima, a Barra Funda é citada como um dos berços do samba, que terá sua vocação reforçada pela implantação da Fábrica dos Sonhos, ainda no âmbito cultural, o Memorial da América Latina também é lembrado. Os shoppings West Plaza e Bourbon são anunciados como centros de consumo e de entretenimento. A própria valorização imobiliária é argumento para a venda, reforçando a especulação.

\subsection{A OUCAB e outras Operações Urbanas Consorciadas no Município de}

\section{São Paulo}

Conforme já mencionado no primeiro capítulo, a OUC é um instrumento urbanístico previsto no Estatuto da Cidade, Lei Federal $n^{\circ} 10.257$ de $2001^{32}$, que oferece autonomia ao Poder Público municipal para realizá-lo. Igualmente, a Lei Federal obriga que as cidades com mais de 20.000 habitantes elaborem um Plano Diretor que oriente a gestão territorial pelo período de dez anos, quando deverá ocorrer sua revisão a fim de ser contextualizado com a realidade local.

No ano seguinte em que o Estatuto da Cidade é sancionado, a prefeitura de SP elabora seu Plano Diretor Estratégico ${ }^{33}$ (PDE). Conforme mencionamos no item 1.3.1, o nome "Estratégico" foi criticado por alguns especialistas (FERREIRA, 2007; MARICATO, 2008; VAINER, 2009) por oferecer uma falsa ideia de construção democrática de cidade, com projetos de Parcerias Público-Privadas (PPP), nas quais acaba por servir aos interesses dos agentes hegemônicos.

O conteúdo por trás do termo "Estratégico" foi defendido na Conferência das Nações Unidas para os Assentamentos Humanos da ONU realizada em Istambul, 1996, na qual se destacou a importância das cidades no atual contexto de globalização econômica e no seu papel de combate à desigualdade social e ambiental tendo como instrumento o Planejamento Estratégico, segundo o modelo apresentado por urbanistas catalães e copiado nas cidades da América Latina (MARICATO, 2008).

Destaca-se, portanto, um exemplo de regulação híbrida, na qual um modelo utilizado em outro continente passa a regular a política urbana na América Latina.

\footnotetext{
31 Regulamenta os artigos 182 e 183 da Constituição Federal de 1988, que dispõem sobre a política urbana.

${ }^{33}$ Lei $n^{\circ} 13.430$ de 13 de setembro de 2002.
} 
Porém, se o PDE foi criticado por poder favorecer agentes hegemônicos, a contrapartida é o Estatuto da Cidade, que garante a participação social por meio dos instrumentos previstos no artigo 43, vejamos:

I - órgãos colegiados de política urbana, nos níveis nacional, estadual e municipal;

II - debates, audiências e consultas públicas;

III - conferências sobre assuntos de interesse urbano, nos níveis nacional, estadual e municipal;

IV - iniciativa popular de projeto de lei e de planos, programas e projetos de desenvolvimento urbano (BRASIL, 2001).

A normatização mencionada faz parte do processo de criação negociada do direito, que Faria (2011) denomina de procedimentalização, conforme mencionado no capítulo anterior, da qual reforça nossa ideia de pluralismo jurídico o que diz respeito à política urbana.

O PDE incorpora esses princípios em seu conteúdo, incluindo a forma de construção de uma Operação Urbana Consorciada (OUC). O que muda a partir do Estatuto da Cidade em relação á OUC, conforme artigo 33, inciso VII, é que o controle social, compartilhado com o controle do Estado, passa a ser componente obrigatório e a forma como se dará este controle deve ser prevista na lei que cria a OUC.

O PDE incorporou ainda o estabelecido no Estatuto da Cidade em relação à OUC e instituiu no artigo 229 os itens que devem conter na lei que cria uma OUC:

[...] I - delimitação do perímetro da área de abrangência;

II - finalidade da operação;

III - programa básico de ocupação da área e intervenções previstas;

IV - estudo prévio de impacto ambiental, de vizinhança;

V - programa de atendimento econômico e social para a população diretamente afetada pela operação;

VI - solução habitacional dentro de seu perímetro ou vizinhança próxima, no caso da necessidade de remover os moradores de favelas e cortiços;

VII - garantia de preservação dos imóveis e espaços urbanos de especial valor histórico, cultural, arquitetônico, paisagístico e ambiental, protegidos por tombamento ou lei;

VIII - instrumentos urbanísticos previstos na operação;

IX - contrapartida a ser exigida dos proprietários, usuários permanentes e investidores privados em função dos benefícios recebidos;

$\mathrm{X}$ - estoque de potencial construtivo adicional;

XI - forma de controle da Operação, obrigatoriamente compartilhado com representação da sociedade civil; 
XII - conta ou fundo específico que deverá receber os recursos de contrapartidas financeiras decorrentes dos benefícios urbanísticos concedidos. [...] (SÃO PAULO, 2002)

Apesar das críticas em relação à construção democrática, para que este instrumento urbanístico ofereça um maior serviço social e includente na cidade depende mais de uma questão política do que técnica durante sua implementação. Conforme Maricato e Ferreira:

[...] uma vez que seu efeito progressista depende da capacidade de mobilização da sociedade civil para garantir que seja regulamentado de forma a assegurar uma implementação segundo os interesses da maioria e não apenas das classes dominantes, e que permita o controle efetivo do Estado e a possibilidade de controle social na sua aplicação. (MARICATO e FERREIRA, 2002, p. 2).

Outras inovações são: i) a obrigatoriedade da elaboração do Estudo de Impacto Ambiental (EIA) e seu respectivo Relatório de Impacto Ambiental (RIMA), que deve ser submetido à audiência pública; ii) a emissão de Certificados de Potencial Adicional de Construção (CEPAC).

A obrigatoriedade do EIA-RIMA estimula a participação social, pois nas audiências públicas devem ser expostos o plano urbanístico proposto e seus impactos no território delimitado. Desta forma, dependendo da capacidade de mobilização da sociedade civil, sua participação pode ser relevante durante a implantação das intervenções urbanísticas.

Quanto ao CEPAC, trata-se de certificados com valores equivalentes ao $\mathrm{m}^{2}$, que são oferecidos aos empreendedores que pretendam construir acima do limite imposto pelo zoneamento do Plano Diretor Estratégico (PDE), ou seja, se antes havia um limite na construção, agora o empreendedor pode comprar quantos CEPACs forem necessários para construir o quanto desejar, pagando pelos $\mathrm{m}^{2}$ que irá utilizar.

Os recursos arrecadados com a venda dos CEPACs devem ser utilizados em obras de infraestrutura no interior do perímetro da OUC, na qual foi vendido o CEPAC.

$\mathrm{O}$ fato da obrigatoriedade de utilizar os recursos do CEPAC dentro do perímetro da OUC é alvo de críticas ${ }^{34}$ porque desta maneira o Poder Público valoriza uma região

\footnotetext{
${ }^{34}$ Os urbanistas João Sette Whitaker Ferreira e Mariana Fix criticam o uso do CEPAC no artigo "A urbanização e o falso milagre do Cepac". Disponível em: <http://www1.folha.uol.com.br/fsp/opiniao/fz1704200110.htm> Acessado em 25 de março de 2014.
} 
específica contribuindo com a especulação imobiliária em detrimento de carências de toda ordem no restante da cidade.

No caso da OUCAB, houve uma mudança interessante em relação ao uso do CEPAC, seus recursos passam a ser utilizados numa área maior que extrapola o perímetro da OUCAB, no chamado perímetro expandido, como veremos adiante.

Desta forma, as Operações Urbanas em vigor, tiveram que ser revistas, tornando-se Consorciadas, agregando o conteúdo do artigo 229 citado.

Além das já existentes OUC: Faria Lima, Água Branca, Centro e Água Espraiada, existem áreas destinadas às futuras $\mathrm{OUC}^{35}$ que foram delimitadas no PDE de 2002, entre elas, a Rio Verde - Jacu, a única aprovada ainda no então governo da prefeita Marta Suplicy (2001 - 2004), mas, não avançou, e a OUC Vila Sônia, que está em andamento para elaboração de lei própria, já tem o Estudo de Impacto Ambiental elaborado. Vejamos no mapa 05 a seguir as propostas de Operações Urbanas Consorciadas em SP.

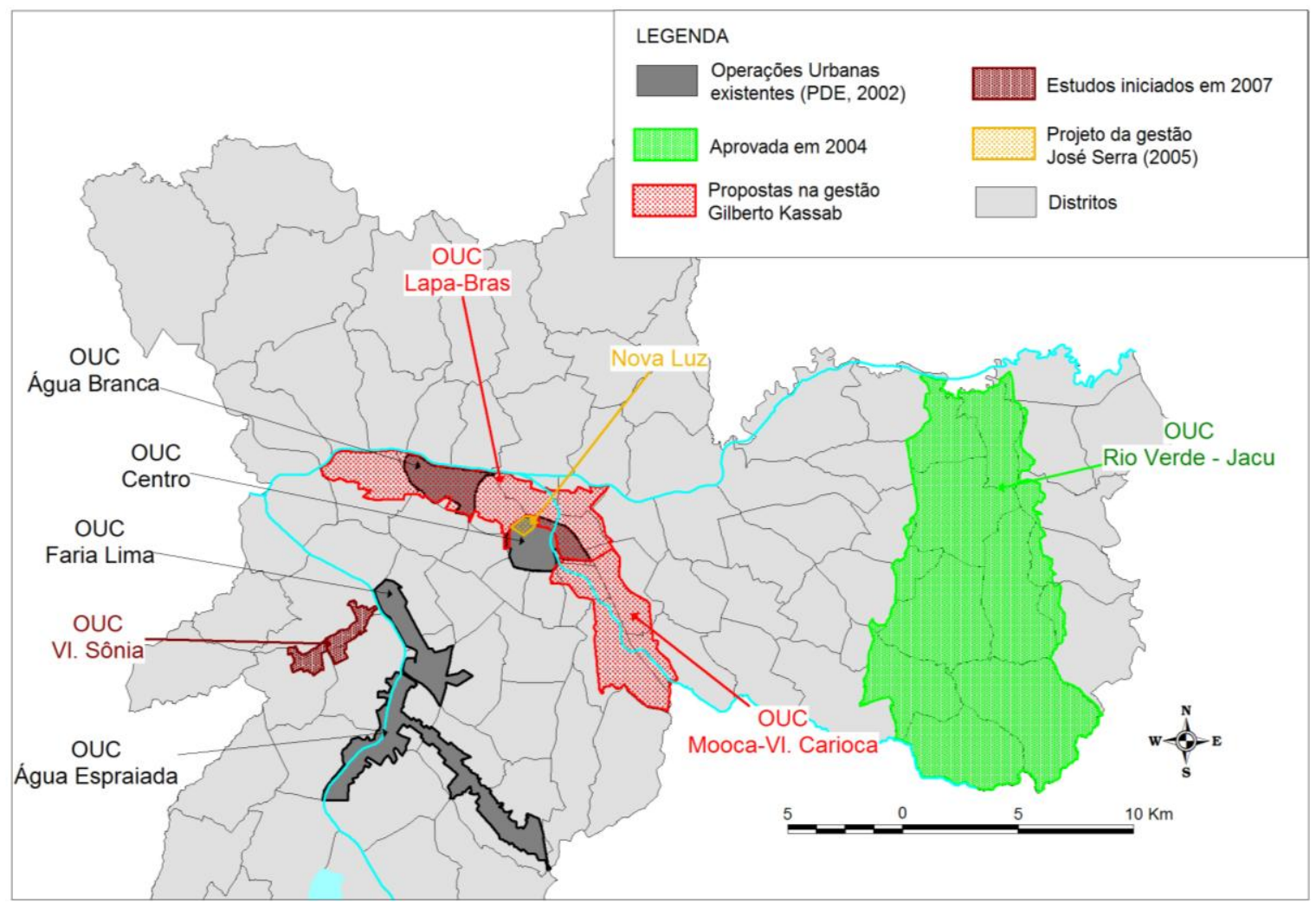

Mapa 5 - Propostas de OUC após Plano Diretor Estratégico de 2002. Elaboração própria ${ }^{36}$. 2014.

\footnotetext{
${ }^{35}$ Diagonal Sul, Diagonal Norte, Carandiru - Vila Maria, Rio Verde - Jacú, Vila Leopoldina, Vila Sônia e Celso Garcia, Santo Amaro e Tiquatira.

${ }^{36}$ Fonte: Mapa Digital da Cidade de São Paulo (MDC).
} 
Ao aprovar a OUC Rio Verde-Jacu, rompeu-se com a lógica apontada por Fix (2001), na qual só se aplicam OUC em áreas de expansão imobiliária ou em áreas deterioradas.

Embora essa OUC ainda não tenha avançado, voltou-se o olhar para a região da Zona Leste da cidade, caracterizada como uma área de bairros dormitórios com grande concentração demográfica, baixa densidade de emprego e altas taxas de desemprego ${ }^{37}$.

Na curta gestão do prefeito José Serra (2005 - 2006), foi lançado o projeto Nova Luz para a região central da Luz, o mesmo se inseria no perímetro da OUC Centro, como visto no mapa 5, entretanto o projeto foi interrompido em 2013 no atual governo de Fernando Haddad.

Foi na gestão do prefeito Kassab (2006 - 2012) que se fez a tentativa de reativar a OUC Rio Verde - Jacu com o lançamento de um Termo de Referência ${ }^{38}$ para contratação de uma ou mais empresas para a elaboração de um estudo urbanístico. Os objetivos principais da prefeitura eram: i) aumentar a relação emprego/habitante com a criação de polos de atividades econômicas geradores de empregos; ii) aumentar a oferta de serviços; iii) melhorar a mobilidade urbana intra-bairros; vi) aplicar o plano de drenagem urbana.

No mesmo período (2007), foi submetido ao Estudo de Impacto Ambiental o perímetro da OUC Vila Sônia (OUCVS). Que atualmente, com a anunciada chegada do metrô começaram a surgir lançamentos de edifícios residenciais, prevendo essa situação e com a intensão de propor um crescimento ordenado e equilibrado, do ponto de vista urbanístico (infraestrutura local), social (com oferta de equipamentos sociais) e ambiental, foi projetada a OUCVS, localizada no mapa 05, contudo, seus estudos ainda estão em fase de aperfeiçoamento e não obtiveram licença de órgãos competentes.

Ademais, foram propostas mais OUC, ilustradas no mapa 05, a Lapa - Brás, que englobaria a OUC Diagonal Norte, a OUC Água Branca e parte da OUC Diagonal Sul, e a Mooca - Vl. Carioca, baseada na Diagonal Sul, proposta no PDE.

As propostas da gestão Kassab surgem sob os auspícios da concepção de “Cidade Compacta”, discutida durante a elaboração da Lei Municipal n 14.933 de

\footnotetext{
37 Apresentação da PMSP feita ao Conselho Municipal do Meio Ambiente e Desenvolvimento Sustentável (CADES). Disponível em: <http://www.prefeitura.sp.gov.br/cidade/secretarias/upload/meio_ambiente/arquivos/apresentacao_cades_ leste.pdf> Acesso em 14 de março de 2014.

${ }^{38}$ Disponível em: < http://www.prefeitura.sp.gov.br/cidade/secretarias/upload/chamadas/trouc_rio_verdejacu_-_versao_consulta_publica_1289322052.pdf> Acesso em 14 de março em 2014.
} 
2009, que institui a política de mudanças climáticas no município de SP, na qual tem por objetivo principal reduzir a emissão de gases do efeito estufa.

O princípio de Cidade Compacta aparece na lei mencionada pautada em algumas metas, por exemplo, estímulo à requalificação de áreas urbanizadas dotadas de infraestrutura e a redução do deslocamento, sobretudo de automóveis particulares e não coletivos, com melhor distribuição de empregos na cidade.

As OUC Lapa - Brás e Mooca - Vl. Carioca tinham como principais objetivos a ocupação da orla ferroviária com melhoramento viário e recuperação das áreas degradadas, remanescentes do passado industrial. Sua implantação previa criar condições viárias favoráveis para a futura demolição do elevado Costa e Silva.

Além disso, ainda na gestão de Kassab, foi dado início no processo de revisão da lei da OUAB para que se tornasse OUCAB (com o " $\mathrm{C}$ " de consorciada) incorporando assim os princípios do Estatuto da Cidade.

Além das iniciativas acerca das OUC, o PDE também foi objeto de revisão nessa gestão. Contudo, a revisão que se iniciou em 2007 por meio de um Projeto de Lei foi questionada pelo Ministério Público e pela oposição, que não permitiram sua aprovação alegando falta de participação social.

Embora a gestão tenha sido marcada por iniciativas em relação às políticas urbanas com vistas à cidade compacta e diminuição dos deslocamentos e da emissão dos gases de efeito estufa, o que se viu em ação, foi o contrário.

Os projetos de OUC não foram levados a cabo, tampouco o processo de revisão do PDE. Em relação aos deslocamentos intraurbanos, houve elevados investimentos no viário da marginal Tietê e muito pouco em transporte coletivo ${ }^{39}$.

A obra na marginal Tietê teve como objetivo a diminuição do tempo das viagens para quem utiliza o viário. Ou seja, o aumento da velocidade de circulação, cara às grandes empresas, é um dos objetivos de normas locais provocando conflitos na medida em que se privilegia apenas o transporte individual.

O Projeto de Lei (PL) do PDE do governo de Kassab foi então arquivado para que um substitutivo, o PL 688/2013, fosse colocado em discussão na atual gestão, prefeito Fernando Haddad. O novo PL pretende trazer novas considerações referentes às OUC. Resta saber se será aprovado.

\footnotetext{
39 Fonte: <http://www.prefeitura.sp.gov.br/cidade/secretarias/comunicacao/noticias/?p=147348> e $<$ http://www.redebrasilatual.com.br/cidadania/2013/05/plano-diretor-de-sao-paulo-foi-desvirtuado-embeneficio-do-carro> Acesso em: 25 maio 2013.
} 
A maior inovação proposta é o compromisso de campanha eleitoral do atual prefeito, o projeto Arco do Futuro.

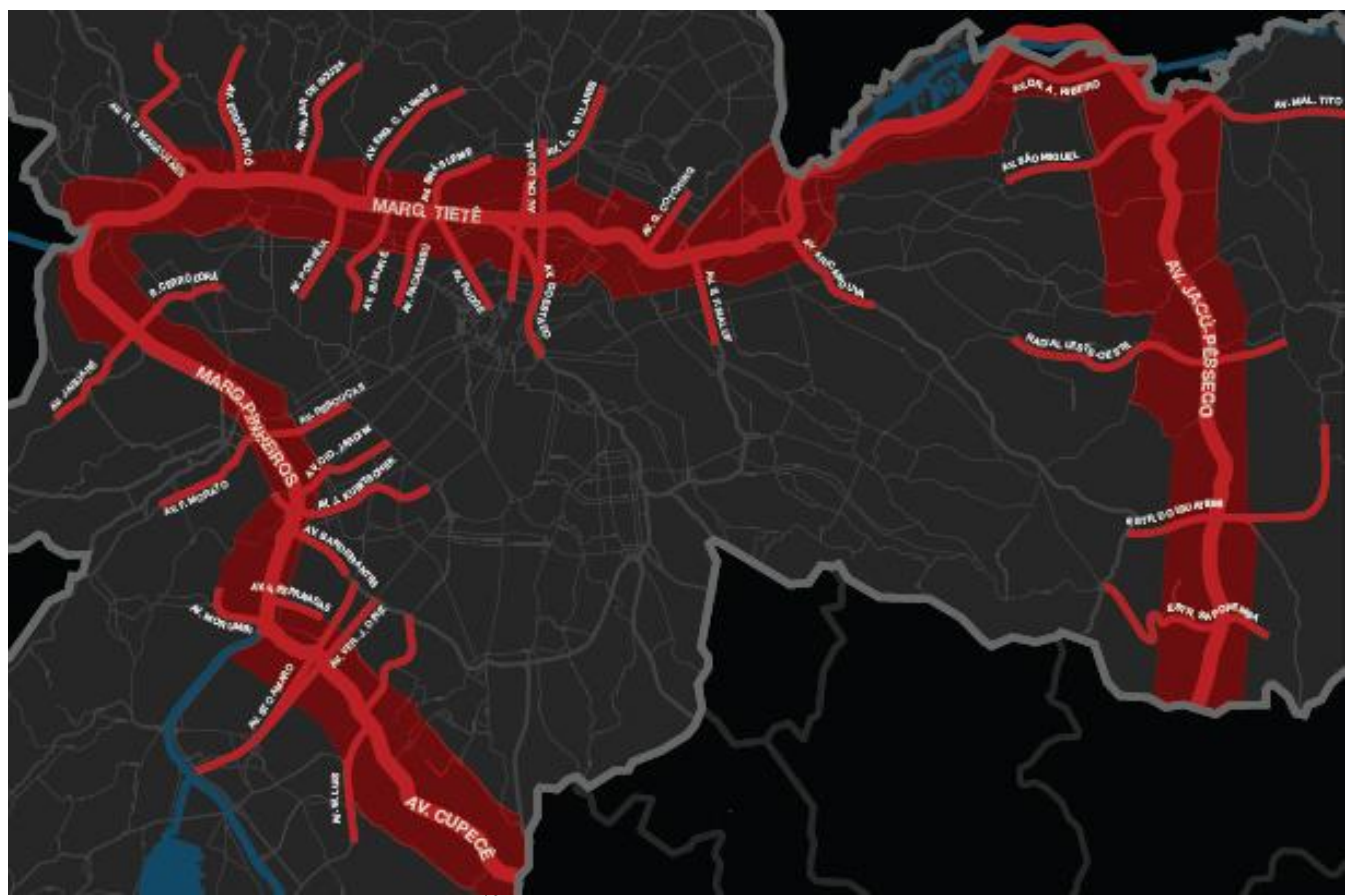

Figura 5 - Arco do Futuro. ${ }^{40}$ PMSP, 2014. Sem norte e sem escala

Seu perímetro linear combina com os dois principais rios da cidade, o Tietê e o Pinheiros, continuando pelo viário Avenida Jacu Pêssego na zona leste e Avenida Cupecê na zona sul. Pretende-se dar novos usos aos terrenos fabris que foram desprezados, ao longo das ferrovias inseridas neste perímetro, preferencialmente moradia para a demanda da população de baixa renda e novos usos produtivos geradores de emprego.

Para além do Arco do Futuro, o PL 688/2013 que deverá substituir o atual PDE prevê seis macroáreas ${ }^{41}$ que definem territorialmente temas para planejamento e gestão urbana e ambiental, a que mais se aproxima do perímetro do Arco do Futuro é a Macroárea de Estruturação Metropolitana, mapa 6.

Para o atual governo municipal, o perímetro ilustrado no mapa 6, contém espaços subutilizados do ponto de vista de habitação, de equipamentos sociais e de empregos, que acabam agravando os desequilíbrios estruturais da metrópole.

\footnotetext{
40 Disponível em: <http://cidadeaberta.org.br/comissao-do-arco-do-futuro-ouve-secretario-dedesenvolvimento-urbano/> Acesso em: 14 mar. 2014.

${ }^{41}$ São elas: a macroárea de preservação de ecossistemas naturais; a macroárea de contenção urbana e uso sustentável; a macroárea de recuperação urbana e ambiental; a macroárea de redução da vulnerabilidade urbana; a macroárea de qualificação da urbanização consolidada; a macroárea de estruturação metropolitana. Disponível em: <http://gestaourbana.prefeitura.sp.gov.br/novo-pde-macroareas/> Acesso em: 14 mar. 014.
} 


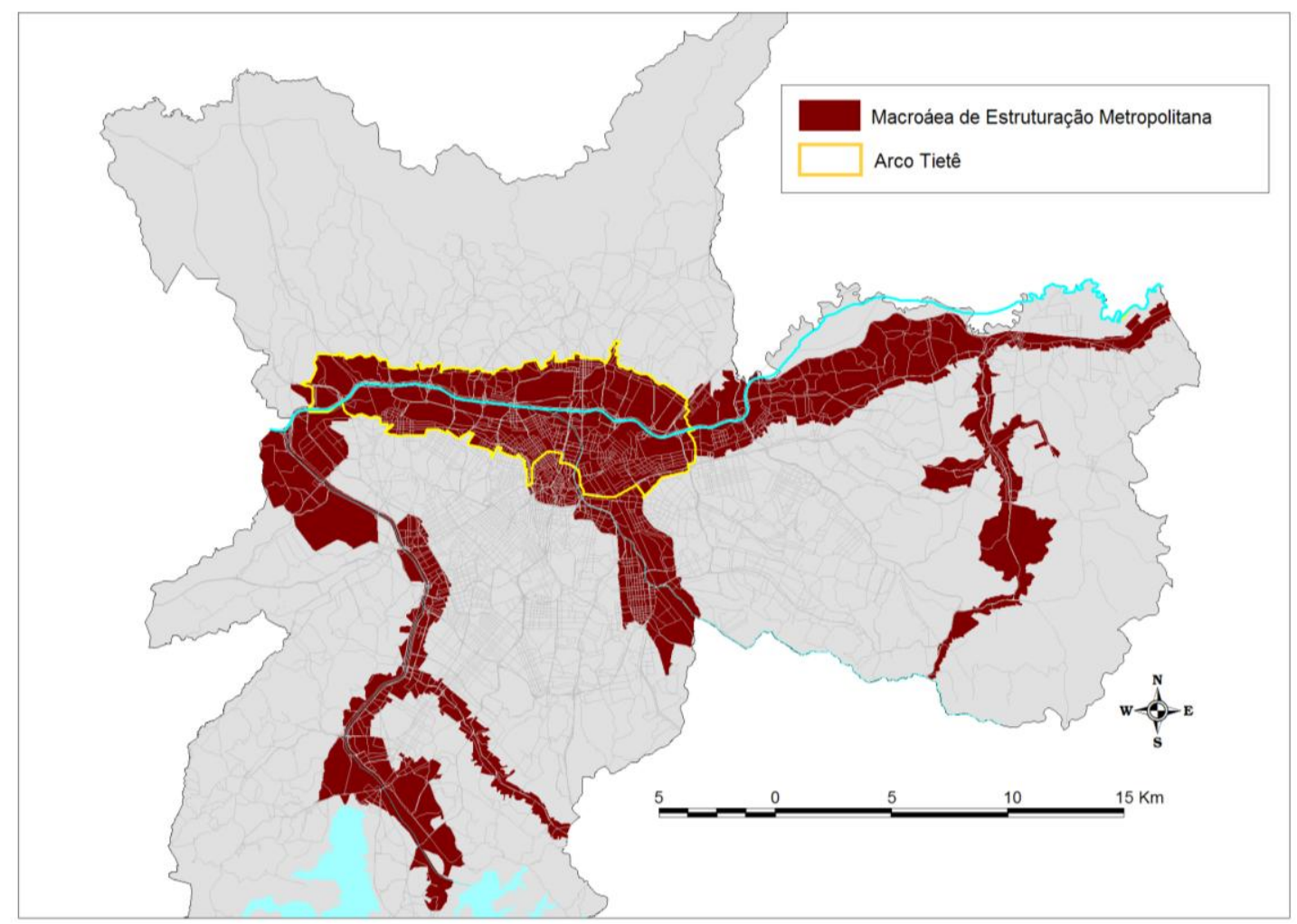

Mapa 6 - Proposta de perímetro de estruturação metropolitana do PL n ${ }^{\circ}$ 688/2013. Elaboração própria $^{42} .2014$

A primeira etapa para a concretização do Arco do Futuro baseada na macroárea de estruturação é o projeto Arco Tietê.

O objetivo para a macroárea de estruturação metropolitana é equilibrar a oferta de moradia e de empregos a partir de planos urbanísticos específicos, que devem diversificar o uso e ocupação do solo em perímetros menores por meio de OUC, que deverão ocorrer somente nesta macroárea.

Desta forma, diferente do PDE atual, o próximo Plano não delimitará previamente nenhuma OUC. Conforme a necessidade e o contexto futuro, mediante estudo detalhado e com a participação da sociedade civil, elaborar-se-á legislação própria delimitando a nova OUC. Se incorporado ao conteúdo do novo PDE, será um ganho, considerando que o uso do território possui uma dinâmica própria que nem sempre corresponde com a norma jurídica. Isto foi o que aconteceu com a Operação Urbana Água Branca, objeto deste estudo.

Outra mudança significativa, é que foi estabelecido o perímetro expandido para as futuras OUC, isto é, áreas que extrapolem o perímetro de uma OUC poderão receber investimentos dos recursos arrecadados nas contrapartidas dos Certificados de Potencial

\footnotetext{
${ }^{42}$ Fonte: Mapa Digital da Cidade de São Paulo (MDC) e PL n ${ }^{\circ}$ 688/2013.
} 
Adicional de Construção (CEPAC) para atender as demandas de moradia da população de baixa renda.

No PDE vigente, isso não é possível, os recursos arrecadados em uma OUC só podem ser utilizados dentro do perímetro da mesma OUC. Essa mudança é resultado dos avanços nas discussões acerca da revisão da lei da OUCAB e das consequências excludentes das OUC Água Espraiada, Faria Lima e Centro.

A tabela 1 nos fornece um panorama geral da arrecadação das OUC em andamento. Uma das grandes críticas já mencionada nesta dissertação é o fato de se utilizar todo o recurso no interior do perímetro da OUC em detrimento de bairros desprovidos de infraestrutura.

Tabela 1: Resumo da Movimentação Financeira das OUC em andamento (Janeiro de 2014).

\begin{tabular}{cccc}
\hline OUC & Entrada & Saída & Saldo \\
\hline Água Branca & $\mathrm{R} \$ 627.367 .071,29$ & $\mathrm{R} \$ 60.859 .810,60$ & $\mathrm{R} \$ 566.507 .260,69$ \\
Centro & $\mathrm{R} \$ 44.261 .850,91$ & $\mathrm{R} \$ 8.282 .463,94$ & $\mathrm{R} \$ 35.979 .386,97$ \\
Faria Lima & $\mathrm{R} \$ 1.977 .832 .298,15$ & $\mathrm{R} \$ 1.465 .362 .530,63$ & $\mathrm{R} \$ 512.469 .767,52$ \\
Água Espraiada & $\mathrm{R} \$ 3.456 .050 .020,47$ & $\mathrm{R} \$ 1.364 .417 .398,26$ & $\mathrm{R} \$ 2.091 .632 .622,21$ \\
\hline
\end{tabular}

Fonte: São Paulo Urbanismo ${ }^{43} .2014$

Sobre esses dados, complementamos com as informações trazidas pelo urbanista Eduardo Nobre, em debate sobre a OUCAB, reunião com a finalidade de preparar a sociedade civil para as audiências públicas que iriam ocorrer:

\begin{abstract}
A área das operações urbanas que foram regulamentas, tem em torno de 3.000 hectares $\left(30 \mathrm{Km}^{2}\right)$, representando $3 \%$ da área urbanizada da cidade de São Paulo; ou seja, numa área de $1.000 \mathrm{Km}^{2}$, só $30 \mathrm{Km}^{2}$ são dessas áreas das operações urbanas regulamentadas e nessas áreas há 5,6 bilhões de reais para serem gastos nesses $3 \%$ por lei. O plano diretor instituiu para o resto da cidade e para as áreas que ainda poderiam ter o potencial construtivo, a outorga onerosa do direto de construir tinha arrecadado 1 bilhão de reais. Então, o Estatuto da Cidade define que os recursos arrecadados na operação urbana tem, por obrigatoriedade serem gastos no interior do perímetro da operação urbana e o resto da cidade arrecadou 1 bilhão de reais que devem ser gastos nos outros $97 \%$ do resto da cidade, ou seja, há 186 vezes mais dinheiro para investir nas áreas de operação urbana pelo montante arrecadado da venda dos CEPACs e da outorga onerosa do direito de
\end{abstract}

\footnotetext{
${ }^{43}$ Disponível em: <http://www.prefeitura.sp.gov.br/>. Resumo da movimentação até 31 jan. 2014
} 
construir, sem entrar no mérito dos orçamentos das subprefeituras, investidos na urbanização e nas obras do interior do seu perímetro. ${ }^{44}$

Vale destacar que, quando Nobre fala em receita de 5,6 bilhões de reais, referese aos dados anteriores à atualização da tabela 01, portanto, a receita a esta altura da pesquisa ultrapassa os 6 bilhões de reais.

A empresa pública SP Urbanismo, que oferece suporte aos trabalhos de planejamento urbano na cidade de SP, faz também o resumo das despesas, e dele verificamos que pouco mais de 580 milhões foram gastos com Habitação de Interesse Social (HIS) nas duas maiores receitas de OUC, a Faria Lima e a Água Espraiada. Enquanto aproximadamente 2,2 bilhões foram gastos com obras e serviços. Segundo Nobre, durante o debate afirmou que metade desse valor foi gasto em obras viárias, ratificando o modelo rodoviarista que São Paulo vem apresentando por mais de meio século.

Para Eduardo Della Manna ${ }^{45}$, apêndice A, representante do Sindicato das Empresas de Compra, Venda e Administração de Imóveis (SECOVI), as OUC Faria Lima e Água Espraiada “[...] já chegaram ao fim e cumpriram sua função na cidade, só falta a Prefeitura utilizar o dinheiro que está em caixa. O que resta é refletir sobre o que deu certo e o que deu errado e melhorar nas próximas intervenções [...]”.

Talvez, o fato de a Prefeitura não ter utilizado o dinheiro em caixa é porque só se pode utilizá-lo no perímetro da OUC que, conforme Della Manna, já cumpriu sua função.

Nota-se, pelo fato citado acima e pelos números apresentados por Eduardo Nobre, quanto ao acúmulo de dinheiro direcionado a uma pequena parte do território urbanizado, que a criação de um perímetro expandido para as OUCs foi mais um avanço que vem sendo incorporado à política urbana da capital paulista, visto que o princípio de redução da desigualdade social preconizado no Estatuto da Cidade (2001) pode se efetivar mesmo fora do perímetro.

Quanto à OUCAB, a urbanista Raquel Rolnik denunciava, desde 2011, que o dinheiro arrecadado ainda não tinha sido aplicado, nenhum centavo, para obra de drenagem, problema histórico na região onde está inserida a OUCAB, a várzea do rio

\footnotetext{
44 As gravações do debate ocorrido em 13 de maio de 2013 podem ser encontradas em: <http://www.casadacidade.org.br/videos-do-debate-sobre-a-operacao-urbana-agua-branca-130513/ >

${ }^{45}$ Entrevista concedida em 25 de fevereiro de 2014.
} 
Tietê. Entretanto, muita coisa aconteceu durante a revisão da lei que cria a OUCAB e nos debruçaremos sobre esse assunto adiante.

Procuramos demonstrar neste capítulo o quadro geral da mudança de uso do território no distrito da Barra Funda ao longo do século XX e começo do século XXI diante do processo de urbanização da cidade de SP, para depois, no próximo capítulo, discutir o papel da norma produzida pelos diversos agentes mediados pelo uso do território. 


\section{A OUCAB, OS AGENTES, o PLURALISMO JURÍDiCO E A PRODUÇÃO DAS NORMAS}

Passado mais de uma década da criação da Operação Urbana Água Branca, o território usado no perímetro delimitado se apresenta como norma proveniente tanto do sistema técnico implantado como das ações a ele direcionadas e contraria a norma jurídica, a lei municipal no 11.774 de 1995 de criação da OUAB.

Pois, o objetivo da lei em transformar o distrito da Barra Funda em um centro de serviços por meio da oferta de um estoque de área de potencial construtivo adicional ${ }^{46}$ não-residencial três vezes maior que o estoque de área residencial não correspondeu com o uso do território, a demanda para o uso residencial foi bem maior.

Ademais, o Poder Público municipal, desde o PDE de 2002, apontava para outro modelo de cidade, no qual procurasse levar postos de trabalho para os bairros de periferia, carentes de empregos, e incentivasse o aumento de população moradora nos distritos centrais, onde há maior oferta de empregos, além de infraestrutura urbana instalada.

Portanto, se a norma jurídica se fez letra morta diante do uso do território no perímetro da Operação Urbana Água Branca (OUAB), uma vez que este se apresenta como uma norma ${ }^{47}$ mais eficiente, era necessária uma adequação à legislação vigente. Igualmente, era necessário também incorporar os princípios do Estatuto da Cidade. Inicia-se, então o processo de revisão da Lei no 11.774 de 1995, que criou a OUAB e sua substituição para a criação da Operação Urbana "Consorciada" Água Branca (OUCAB).

\subsection{A discussão no processo de licenciamento ambiental}

Em 2007, a Empresa Municipal de Urbanização (Emurb) ${ }^{48}$ elaborou um plano urbanístico preliminar para a OUCAB propondo um adensamento significativo de moradores, saltando de, aproximadamente, 30.000 habitantes para 115.000 até o ano de

\footnotetext{
46 Potencial construtivo adicional significa área disponível para construção além do permitido pelo zoneamento da região, mediante pagamento de contrapartida para a Prefeitura.

${ }^{47}$ Pensamos aqui o território como norma segundo Antas Jr., num “[...] condicionamento dos usos das técnicas, de seus produtos (os objetos técnicos) e, por extensão, das relações sociais” (2005, p. 39).

${ }^{48}$ Empresa extinta em 2009, que deu origem às empresas municipais São Paulo Urbanismo e São Paulo Obras.
} 
2025. Segundo Sr. Vladir Bartalini, diretor da SP Urbanismo ${ }^{49}$ a região da Operação Urbana tem uma população de 19 habitantes por hectare, o que equivale a uma área de $10.000 \mathrm{~m}^{2}$, enquanto o distrito vizinho, Santa Cecília, tem 170 habitantes por hectare.

Para o Sr. Bartalini ${ }^{50}$ a intensão da SP Urbanismo é priorizar a população que mais utiliza os equipamentos de transporte público da região levando-os a morar perto de seu emprego, pois há a predominância de postos de trabalho no distrito, herança do passado industrial do uso do território.

O plano urbanístico divide o território da OUCAB em nove setores, do setor A ao setor I, conforme a figura 6 a seguir.

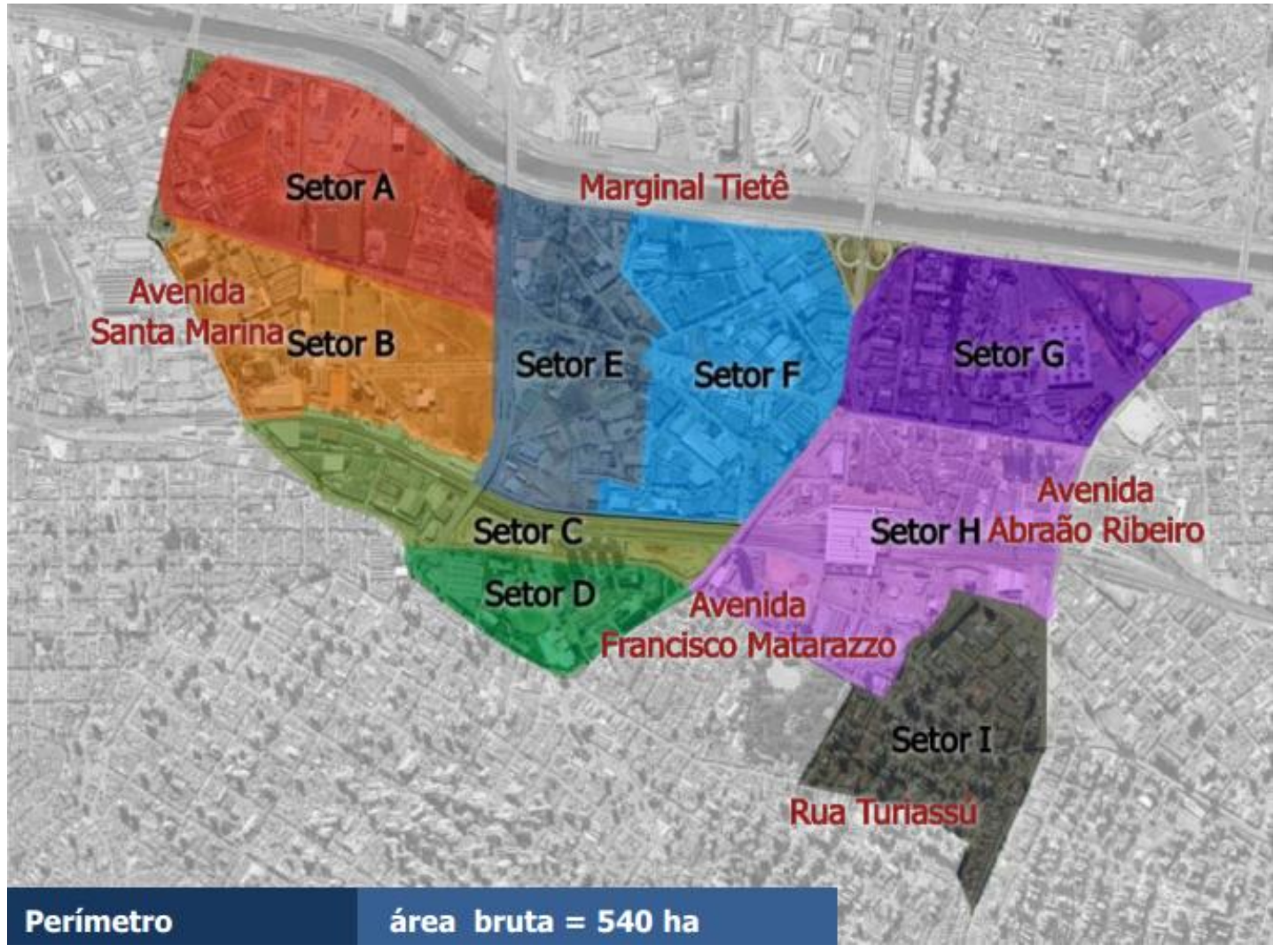

Figura 6 - Setorização do território da OUCAB antes do licenciamento ambiental. Fonte: Prefeitura do Muncípio de São Paulo ${ }^{51}$, 2009. Figura sem escala.

Os setores receberam as seguintes denominações: A - ZEIS e Centro de Treinamento; B - Santa Marina Gleba Telefônica; C - Orla ferroviária; D - Sociedade Esportiva Palmeiras - West-Plaza; E - Gleba Pompéia - Marginal Tietê; F - Parque

\footnotetext{
${ }^{49}$ Empresa Municipal que atua na área de planejamento urbano.

${ }^{50}$ Fala de apresentação da OUCAB na primeira audiência pública em 04 de novembro de 2010.

${ }^{51}$ Apresentação do Plano Urbanístico da OUCAB feita pelos técnicos da Emurb em 2009. Disponível em: $<$ http://www.prefeitura.sp.gov.br/cidade/secretarias/upload/desenvolvimento_urbano/sp_urbanismo/arqui arq/ouab/ouab_relatorioreuniaotecnica09jan.pdf> Acesso em: 12 fev. 2014.
} 
Industrial Tomás Edison; G - Playcenter - Fórum Dr. Mário Guimarães; H - Terminal Intermodal Barra-Funda - Memorial da América Latina; I - Bairro de Perdizes.

Esses setores foram criados para orientar a intervenção, por exemplo, os setores ao sul da ferrovia: D, parte do H e I, tem menor demanda por intervenções, segundo Sr. Bartalini, pois possuem mais da metade da ocupação de uso residencial, $8 \%$ de serviços de vizinhança e $35 \%$ de serviços regionais ${ }^{52}$. Nesses setores, é projetado o aumento de serviços de vizinhança.

Nos setores ao norte da ferrovia predominam os serviços regionais influenciados pela presença de indústrias. O uso residencial corresponde a 12\%. Nesses setores, pretende-se aumentar consideravelmente o número de moradores com o aumento de oferta de serviços de vizinhança de maneira compatível, além da diminuição nos serviços regionais.

Quanto à infraestrutura urbana, a Secretaria do Verde e do Meio Ambiente (SVMA), responsável pelo licenciamento ambiental, identifica a seguinte situação: mais de $90 \%$ da ocupação é servida por abastecimento de água, possui esgotamento sanitário e coleta de lixo. Quanto à educação, não foram encontradas instalações nos setores A, C, F e G. Em relação à saúde, os setores A, C, E e F não possuem equipamentos, o setor $\mathrm{B}$ tem um equipamento da administração privada, no setor $\mathrm{D}$ existem dois no setor $\mathrm{H}$ há quatro postos de atendimento de saúde.

O plano foi submetido, em 2009, a um estudo de capacidade de suporte de infraestrutura para avaliar se o adensamento proposto seria compatível com as obras e intervenções planejadas. Ainda no mesmo ano foi contratado o Estudo de Impacto Ambiental.

A partir de então foram feitas audiências públicas, além da tramitação do processo no Conselho Municipal do Meio Ambiente e Desenvolvimento Sustentável (CADES), órgão consultivo e deliberativo composto por trinta e seis pessoas, sendo dezoito membros da sociedade civil e dezoito do Poder Público. Começa, então, a participação direta dos grupos sociais organizados na elaboração da nova lei. Um caso de pluralismo jurídico do tipo progressista, considerado comunitário-participativo.

Ao se dividir a participação dos membros do conselho entre metade do Poder Público e metade da representação social, pode-se dizer que a sociedade civil representa

\footnotetext{
${ }^{52}$ Para o Sr. Bartalini, serviços de vizinhança são aqueles de uso do dia-a-dia como padaria, farmácia e o pequeno mercado e o serviço regional corresponde às escolas, faculdades e shopping center.
} 
a contraposição ao Estado, mas que, nesse momento assume o papel de complementaridade às decisões do mesmo.

Bobbio (2011) atesta que a noção de "sociedade civil" como oposição ao Estado pode assumir três aspectos: i) o pré-estatal, que são as várias formas de organização entre os indivíduos que surgiram antes do Estado; ii) o anti-estatal, manifestado nos grupos que buscam a emancipação do Poder Público, iii) e o pós-estatal, o ideal de sociedade sem o Estado.

O caso aqui estudado é aquele que busca a emancipação do Poder Público, mas, há duas ressalvas importantes, a primeira é que a emancipação social é permitida e oferecida pelo Estado, uma vez que se trata de uma Parceria Público-Privada (PPP). A segunda, diz respeito à heterogeneidade da sociedade civil, vale dizer que há setores divergentes dentre as diversas organizações sociais que participam do processo com destaque à conselheira que representa os moradores da região e o conselheiro representante do setor imobiliário e isto ficará evidente quando a discussão chegar à Câmara Municipal de São Paulo (CMSP).

Embora tenha ocorrido a participação social nesta etapa, a discussão foi predominantemente técnica - num exemplo da técnica também como norma -, o que dificultou a compreensão de boa parte da população envolvida no plano urbanístico apresentado. Por outro lado, como será exposto, houve um esforço por parte das lideranças das associações sociais em realizar reuniões temáticas a fim de contribuir para a maior participação possível.

Por intermédio de uma representante da sociedade civil e do Movimento Defenda São Paulo no CADES, houve a primeira reunião temática sobre o conteúdo do EIA-RIMA da OUCAB com lideranças de entidades sociais em 26 de outubro de 2010.

Nesta reunião foram elaboradas algumas questões e enviadas à SVMA antes da primeira audiência pública. Os questionamentos se referiam a: i) capacidade do suporte viário para o adensamento proposto; ii) planos para os problemas de drenagem; iii) imóveis tombados como patrimônios históricos; iv) previsão de equipamentos sociais de saúde e educação; v) segregação social, já que o plano previa habitação para baixa renda ao norte da ferrovia e de renda mais elevada ao sul da ferrovia; vi) áreas contaminadas; vii) cronograma das principais obras; viii) compatibilização da OUCAB com as demais obras (Arena Palmeiras, Fábrica dos Sonhos). 
$\mathrm{Na}$ primeira audiência pública, alguns segmentos da sociedade civil protocolaram suas demandas, que foram juntadas no Processo Administrativo do licenciamento ambiental da OUCAB para que fossem considerados pelo órgão licenciador. Entre elas destacamos as seguintes:

a) Associação dos moradores da Vila Turiassu: reclama uma intervenção prevista na Rua Cotoxó. Segundo a Associação, a intervenção prejudicaria o tráfego, beneficiaria o Shopping Bourbon e, ainda, seriam necessárias algumas desapropriações de edificações recém-construídas ou reformadas com a autorização da prefeitura, mesmo sabendo que seriam desapropriadas posteriormente;

b) CADES: por meio da conselheira, representante da macro região centro oeste 1 , Lapa, Pinheiros e Butantã. A demanda protocolada refere-se aos mesmos questionamentos citados acima;

c) Associação de ambientalistas e amigos do parque da Água Branca: solicitam a inclusão de nascentes do parque na relação de Áreas de Proteção Permanente (APP);

d) Conselho Comunitário de Segurança $\left(\right.$ Conseg $\left.^{53}\right)$ de Perdizes: solicita que os estudos referentes à obra de reforma do estádio Arena Palmeiras sejam considerados no EIA-RIMA da OUCAB.

Além disso, havia textos protocolados por munícipes que tinham suas demandas, mas, não conheciam o plano urbanístico em sua plenitude. Entretanto, registraram suas demandas, o que confirma a efetivação da participação social. Suas solicitações foram em relação à necessidade de urgência nas obras de drenagem e a resolução dos problemas de enchentes.

Igualmente, houve pessoas que não protocolaram solicitações, mas, puderam fazê-las oralmente e suas manifestações foram registradas na ata da audiência. As intervenções orais foram acerca de moradia popular, problemas de enchente na região e sobre a obra da Arena Palmeiras.

Houve, ainda, manifestações de representantes de moradores de favelas da zona norte da cidade solicitando que o Poder Público intervenha por eles, alegando estarem

\footnotetext{
${ }^{53}$ O Conseg foi criado por meio Decreto Estadual n. ${ }^{\circ} 23.455$ em 1985. Cada CONSEG exige a participação do Delegado de Polícia Titular e do Comandante da Polícia Militar no bairro ou município onde funciona o Conselho, além e entidades da sociedade civil. Disponível em: <http://www.conseglapa.com.br/o-que-e-o-conseg/>. Acesso em: 22 fev. 2014.
} 
esquecidos do outro lado do rio Tietê e que também querem morar na região de Operação Urbana, próxima ao emprego.

Nota-se que houve desde solicitações mais restritas e particulares até as mais abrangentes, essas eram comuns à maioria das lideranças e setores da sociedade civil. Contudo, destacamos o citado no item d, sobre a Arena Multiuso Palmeiras, com a finalidade de esclarecer uma situação que também foi mencionada pelo CADES.

Alguns projetos, como a reforma do estádio do clube Palmeiras ou a instalação da Fábrica dos Sonhos (que deverá abrigar 14 escolas de samba com espaço para elaboração de seus trabalhos), não foram submetidos ao Estudo de Impacto Ambiental (EIA), mas, apenas ao Estudo de Impacto de Vizinhança (EIV). A principal diferença é que no primeiro há a obrigatoriedade de audiência pública e o envolvimento da sociedade civil, no caso do EIV, não há essa obrigação.

Todavia, se esses projetos são submetidos ao EIV, logo não são considerados no EIA-RIMA da OUCAB e estão fora do debate. Essa situação levantada no CADES contraria setores da sociedade civil como o Conseg de Perdizes.

Segundo a representante no CADES entrevistada (Apêndice B), a Sra. Ros Mari Zenha, esses empreendimentos deveriam estar no EIA-RIMA da OUCAB para que os impactos cumulativos fossem considerados e a sociedade civil pudesse intervir.

Diferente do setor imobiliário, que, segundo representante do Secovi ${ }^{54}$, Sr. Eduardo Della Manna, o Relatório de Impacto de Vizinhança emitido pelo órgão licenciador apresenta várias exigências, tanto à Arena Palmeiras quanto à Fábrica dos Sonhos e o cumprimento dessas exigências é a condição para a emissão de alvará de funcionamento. Portanto, o Sr. Della Manna acha desnecessário submeter os estudos desses dois projetos ao Estudo de Impacto Ambiental da OUCAB.

Após a primeira audiência pública, houve uma reclamação por parte dos moradores da região, que, por meio de abaixo-assinados ${ }^{55}$, solicitaram outras audiências púbicas, inclusive temáticas, alegando que o pouco tempo e os termos técnicos utilizados não permitiram o esclarecimento devido diante do detalhamento que o caso requer.

\footnotetext{
${ }^{54}$ Sindicato das Empresas de Compra, Venda, Locação e Administração de Imóveis Residenciais e Comerciais de São Paulo.

${ }^{55}$ Diversas associações de bairros, além dos Conseg da Lapa e de Perdizes apoiaram a solicitação de novas audiências públicas.
} 
Percebe-se a demonstração do esforço da comunidade local em se preparar para uma participação mais eficiente com maior poder de negociação na elaboração da norma, considerando que essa modalidade de pluralismo jurídico coloca em jogo a relação de forças em vigor entre os diversos setores da sociedade civil.

Foi enviada, também, uma carta assinada por várias associações de moradores, destacando a importância histórica, arquitetônica, cultural e afetiva dos imóveis fabris, representativos do período industrial que marcou o início da ocupação dos bairros da região. Solicitam-se destinações criativas aos imóveis como museus, centros de ciência e cultural em detrimento de suas demolições.

De fato, com a ocorrência da primeira audiência pública a sociedade civil vai se organizando. As associações de bairro se unem nessa etapa do processo para entender as demandas de toda a região afetada. Esse entendimento e articulação passam a reverberar na produção da lei da OUCAB.

As lideranças envolvidas no debate fizeram uma reunião com a população moradora na Zona Especial de Interesse Social (ZEIS), que são territórios ocupados pela população de baixa renda, normalmente são favelas, cortiços, conjuntos habitacionais irregulares e habitações coletivas precárias ${ }^{56}$. No perímetro da OUCAB, a ZEIS corresponde à comunidade de Vila Chalot, setor A da figura anterior, comunidade com aproximadamente 2.000 famílias, que está no bairro há pouco mais de 40 anos.

A reunião teve por finalidade a preparação para a segunda audiência pública, que iria ocorrer em 27 de janeiro de 2011. Do encontro resultou uma carta enviada à Secretaria do Verde e do Meio Ambiente (SVMA), a qual foi juntada ao processo de licenciamento da OUCAB. Seu conteúdo versa sobre os seguintes questionamentos: i) Alteração na rua Professor Nelo Lonrezon e seu impacto; ii) Destino do córrego Água Branca (será canalizado ou não); iii) O que será feito para conter as inundações e se há estudos dos outros córregos inseridos no perímetro da OUCAB; iv) O porquê não está prevista a instalação de equipamentos públicos para a comunidade, como creches, postos de saúde e escolas.

Conforme a figura 07, a seguir, nota-se que a comunidade se localiza próxima do rio Tietê e tem a sua direita o córrego Água Branca. Além disso, percebe-se que não se trata de área residencial pelo aspecto dos imóveis do entorno, a ocupação se encontra

\footnotetext{
${ }^{56}$ Conforme a lei de zoneamento da cidade de São Paulo, lei n ${ }^{\circ} 13.885$, de 25 de agosto de 2004.
} 
em meio a grandes galpões industriais e comerciais, o que implica na ausência de equipamentos públicos de saúde e de educação.

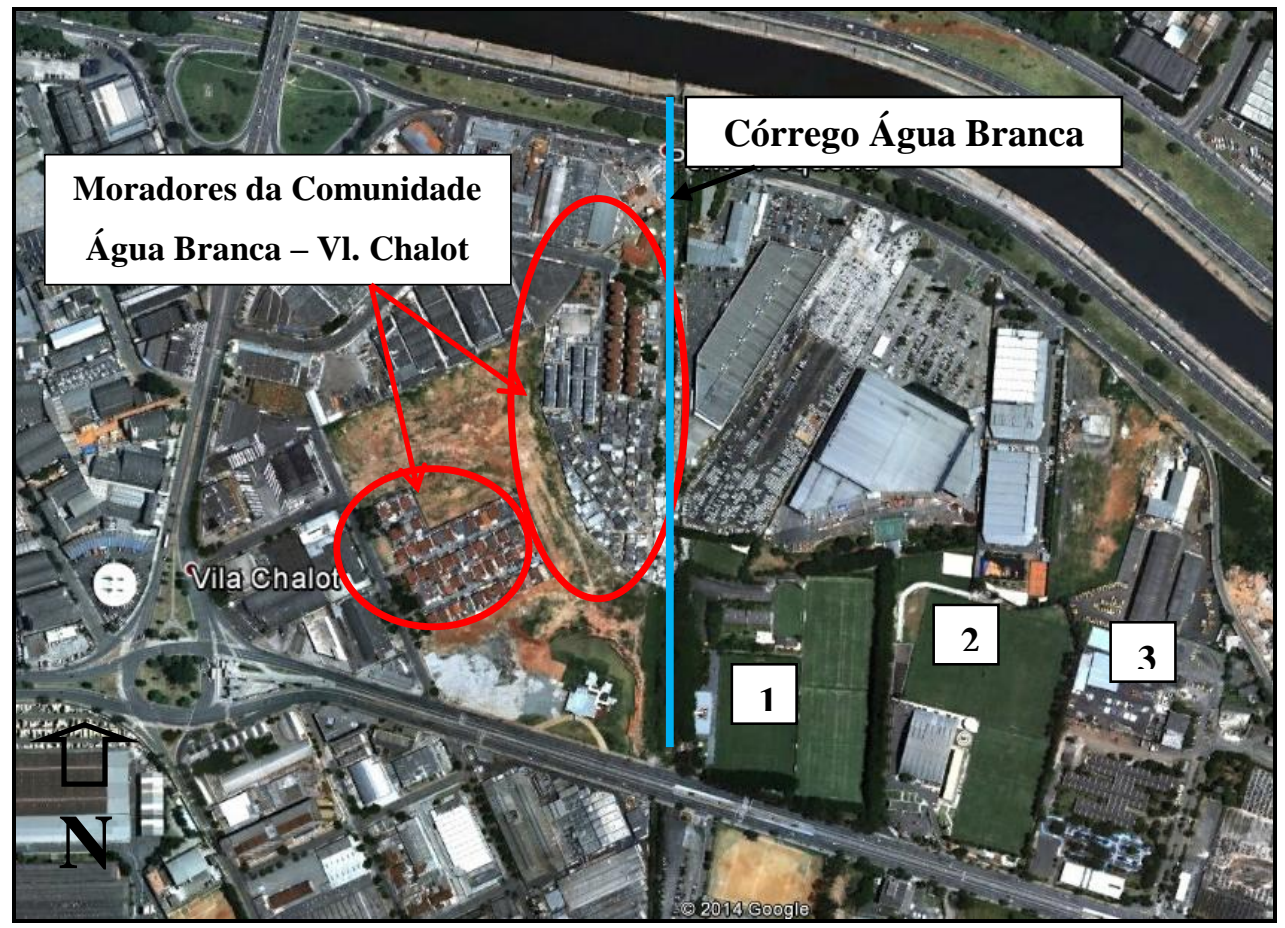

Figura 7 - Localização da comunidade Água Branca.

Obs.: Os lotes numerados correspondem a: 1 - Centro de Treinamento do São Paulo Futebol Clube; 2 - Centro de Treinamento da Sociedade Esportiva Palmeiras; 3 - Companhia de Engenharia de Tráfego (CET). Fonte: Google Earth. Imagem sem escala. Ano 2014

Destacamos também na figura os terrenos numerados correspondentes aos Centros de Treinamentos de futebol de dois clubes populares e da Companhia de Engenharia de Tráfego (CET), que são áreas municipais utilizadas por meio de concessão e que se tornam objeto de discussão pela sociedade civil com a finalidade de serem utilizadas pelo público em geral e deixarem o uso particular. Mais adiante veremos com mais detalhes esses três casos.

A mesma carta elaborada na reunião com a comunidade da Vila Chalot foi protocolada na audiência pública que aconteceu em 27 de janeiro de 2011. Ressaltamos que não encontramos a ata desta audiência pública, nem no processo de onde foram retirados todos os documentos protocolados, nem no site da SVMA, no qual se encontram as atas das audiências públicas de empreendimentos licenciados por esse órgão licenciador. Sendo assim, não temos acesso aos registros orais manifestados pela sociedade civil e nos limitamos aos documentos protocolados.

Mesmo depois dos questionamentos realizados, após a segunda audiência pública, as dúvidas ainda eram as mesmas: i) Quais seriam os impactos dos grandes 
projetos (Arena Multiuso Palmeiras e Fábrica dos Sonhos) associados aos impactos da OUCAB? ii) Qual seria a localização dos equipamentos públicos, sobretudo, hospital, escola e creche? iii) Como ficariam as intervenções para amenizar os problemas das inundações?

No primeiro capítulo, item 1.1.2, destacamos que a promoção das cidades no cenário mundial é um fato que vem ocorrendo para a atração de investimentos internacionais, os projetos da Arena Multiuso Palmeiras, empreendimento particular, e da Fábrica dos Sonhos, empreendimento público, exercem essa função no perímetro da OUCAB.

Mas, destacamos também que a eficácia das ações, influenciada por fatores externos, encontra maior ou menor resistência da organização local, dependendo de suas peculiaridades. A comunidade envolvida na OUCAB se posicionou, quer saber das consequências dos empreendimentos e quais as contrapartidas em equipamentos sociais demonstrando a necessidade de escolas, creches, hospitais e a urgência da resolução dos problemas de drenagem.

A solicitação de mais audiências públicas e temáticas para poderem aproveitar melhor o tempo discutindo assuntos específicos, também marcaram as reivindicações. Contudo, as audiências públicas não ocorreram.

A despeito das demandas sociais no perímetro da OUCAB, em 09 de fevereiro de 2011 funcionários da Prefeitura Municipal de São Paulo derrubaram dezessete barracos da favela do Sapo (comunidade da Vl. Chalot) e expulsaram as famílias que ali moravam. As fotos 5 e 6, a seguir, copiadas do blog do Movimento Água Branca ${ }^{57}$, importante canal de comunicação da sociedade civil, mostram a presença de policiais na ação de remoção das moradias.

\footnotetext{
${ }^{57}$ Disponível em: <http://movimentoaguabrancasp.blogspot.com.br/>. Acesso em: 15 fev. 2014.
} 


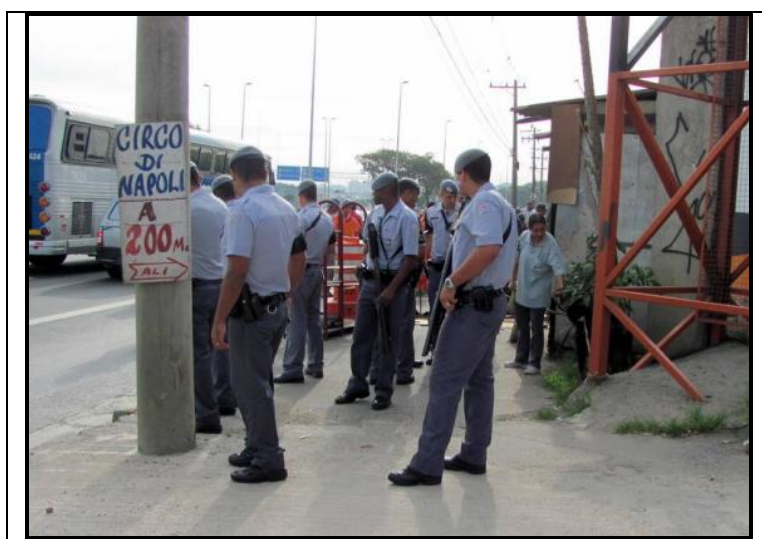

Foto 5 - Presença policial coercitiva no despejo de favelados. 2011

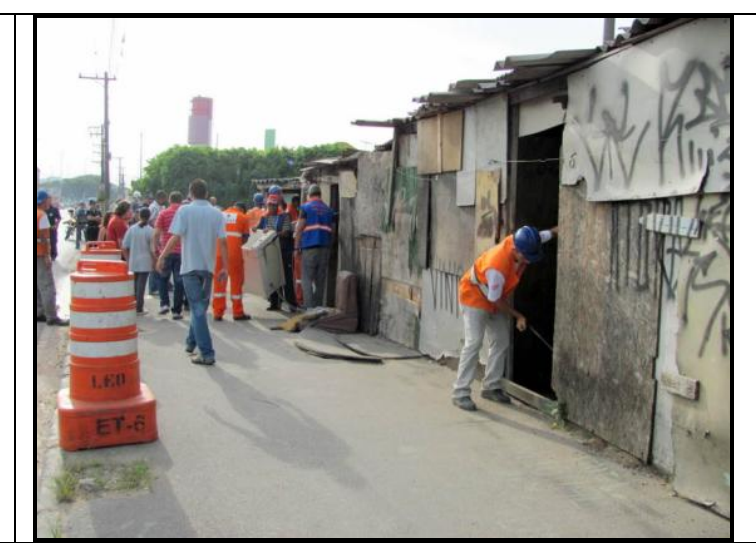

Foto 6 - Desmontagem de moradias. 2011

A ação gerou protestos da comunidade que passou a questionar a utilização das propriedades municipais como Centro de Treinamento, figura 07, pelo São Paulo Futebol Clube e pela Sociedade Esportiva Palmeiras por meio de concessão. Ou seja, os clubes não pagam nada para a utilização dos lotes municipais enquanto o direito à moradia fica cerceado para aquelas famílias.

O caso foi questionado pela Sra. Ros Mari, conselheira do CADES, junto à Subprefeitura, alegando que, por não haver mandato judicial para a ação de despejo, a defensoria pública pôde parar a ação. Contudo, seus questionamentos não tiveram resposta.

Esses terrenos entraram na lista de reivindicações da sociedade civil de maneira geral e vai ser debatida na Câmara Municipal como veremos no próximo item. Os técnicos da SVMA recomendaram que os dois Centros de Treinamento, ao final do prazo de concessão fossem transformados em áreas verdes a serem incorporadas ao parque urbano que se pretende implantar no terreno que atualmente é ocupado pela CET.

Com base nas discussões das duas audiências públicas, nas quinze reuniões do CADES (a primeira em 30/09/2010 e a última em 20/03/2012) e em vistorias, os técnicos da Secretaria o Verde e do Meio Ambiente, órgão licenciador da OUCAB, enviaram, em 20 de março de 2012, um parecer técnico para a SP Urbanismo contendo recomendações para constarem no Projeto de Lei e as exigências para a emissão de licença ambiental.

Nesse Parecer foi destacada a atuação do mercado imobiliário. Segundo o estudo, a região ao norte da ferrovia no perímetro da OUCAB é alvo de lançamentos 
imobiliários verticais para atender a demanda da classe média-alta, o que resulta no aumento do preço da terra, ou seja, na valorização imobiliária.

Por isso, urge a criação de incentivos para a população de baixa renda. A disputa é operacionalizada por meio das formas naturais e artificiais, que condicionam e são condicionadas pelas ações dos grupos sociais.

As grandes glebas que remetem ao passado industrial no perímetro da OUCAB se transformaram em objetos de desejo dos promotores imobiliários e desencadearam uma série de atitudes por parte das pessoas, das empresas e das instituições que rebateriam no território, e que se traduzem em ocupações, desapropriações e apropriações.

$\mathrm{Na}$ tentativa de captar o movimento do território usado, a produção da norma jurídica recebe algumas alterações.

Ao término das discussões no âmbito do Poder Executivo Municipal, o território da OUCAB teve novas divisões, os setores foram divididos em subsetores, conforme a figura 08, respeitando assim, as peculiaridades de cada área para a intervenção e adensamento propostos.

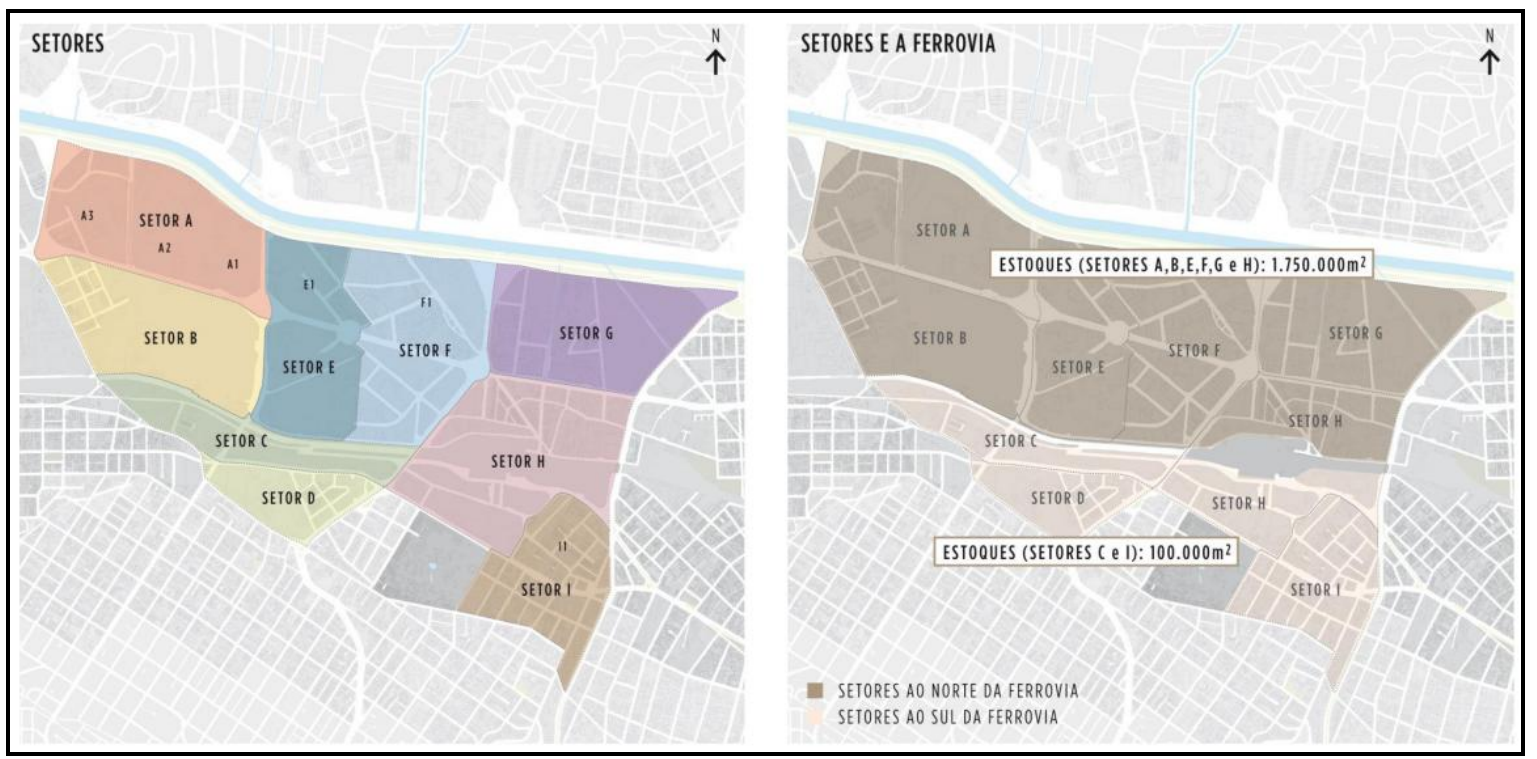

Figura 8 - Nova divisão do território da OUCAB e incentivo de adensamento. Fonte: Prefeitura do Município de São Paulo ${ }^{58}$. Sem escala, 2012.

\footnotetext{
${ }^{58}$ Apresentação do Plano Urbanístico realizada pelos técnicos da SP Urbanismo em 2012. Disponível em: $<$ http://www.prefeitura.sp.gov.br/cidade/secretarias/upload/desenvolvimento_urbano/arquivos/apresentac ap_23_reuniao_ouab.pdf> Acesso em: 12 fev. 2014.
} 
Assim, o incentivo de adensamento é maior ao norte da ferrovia, mas, os setores A; E1; F1 e G, por se localizarem mais próximo ao rio Tietê e estarem inseridos na várzea natural do rio, tiveram uma proposta de adensamento mais restritiva.

É também ao norte da ferrovia que se situam as áreas contaminadas pelos usos industriais pretéritos, conforme vimos no item anterior. O setor de moradores do perímetro da OUCAB solicitaram explicações sobre os impactos que tais áreas poderiam causar. Houve uma reunião temática sobre o assunto, na subprefeitura da Lapa em 27 de fevereiro de 2013. O que se conclui, é que por mais que se demonstre que o gerenciamento das áreas contaminadas elimine o risco de contaminação, as lideranças locais parecem não entender e continuam reclamando soluções e ameaçando denunciar os casos ao Ministério Público.

Em contrapartida, em entrevista concedida pelo representante do SECOVI, Sr. Della Manna, apêndice A, o gerenciamento das áreas contaminadas tem sido feito pelo próprio setor (imobiliário), que aliás vem agregando conhecimento ao ramo da construção, contudo, a eliminação do risco pode levar mais de cinco anos, o que acaba por atrapalhar a venda do imóvel.

Com o mercado imobiliário em alta, a avidez do setor é contida pela norma jurídica, que limita sua ação. Por sua vez, a lei que institui o gerenciamento de áreas contaminadas foi concebida em função da interação entre o uso pretérito e a demanda atual do território.

Até então, a OUAB de 1995 ainda vigente e não a Consorciada, teve esgotado seu estoque de $300.000 \mathrm{~m}^{2}$ para construção residencial, dos $900.000 \mathrm{~m}^{2}$ de estoque para uso não residencial foram utilizados $254.000 \mathrm{~m}^{2}$, a densidade populacional chegava a 25 hab/ha e os recursos originados das contrapartidas eram de 180 milhões de Reais, destinados a obras no sistema viário e no sistema de drenagem (córrego da Água Preta e córrego Sumaré).

Em dezembro de 2012, o então prefeito Giberto Kassab enviou a minuta do Projeto de Lei (PL) para ser avaliada na Câmara Municipal de São Paulo (CMSP). Do PL destacamos as principais alterações em relação a lei vigente:

a) Alteração nos estoques de potencial adicional de construção;

De acordo com o objetivo de levar moradia à região, o Projeto de Lei propõe é aumentar o estoque máximo de potencial adicional de construção residencial de 300.000 para 1. 050.000 (um milhão e cinquenta mil) metros quadrados e o estoque 
máximo de potencial adicional de construção não residencial que pela lei vigente é de 900.000, fica reduzida a 800.000 (oitocentos mil) metros quadrados, totalizando 1.850.000 (um milhão oitocentos e cinquenta mil) metros quadrados.

O incentivo ao adensamento construtivo e populacional não se fez sem questinamentos. A diretora do Movimento Defenda São Paulo, a arquiteta Lucil Lacreta, lembrou durante sua manifestação na audiência pública, que a Operaçao Urbana tem por princípios trazer melhorias para a população residente, entretanto, as melhorias ficam em segundo plano, condicionadas ao adensamento. Até o momento aqui contextualizado, nada tinha sido feito de melhoria, a Sra. Lacreta perguntou se realmente essas melhorias virão e se serão compatíveis com o adensamento induzido.

b) A criação de um perímetro expandido;

O perímetro expandido foi uma grande inovação em matéria de Operação Urbana, vejamos sua abrangência na figura 09 e as Zonas Especiais de Interesses Especiais (ZEIS) inseridas em seu interior:

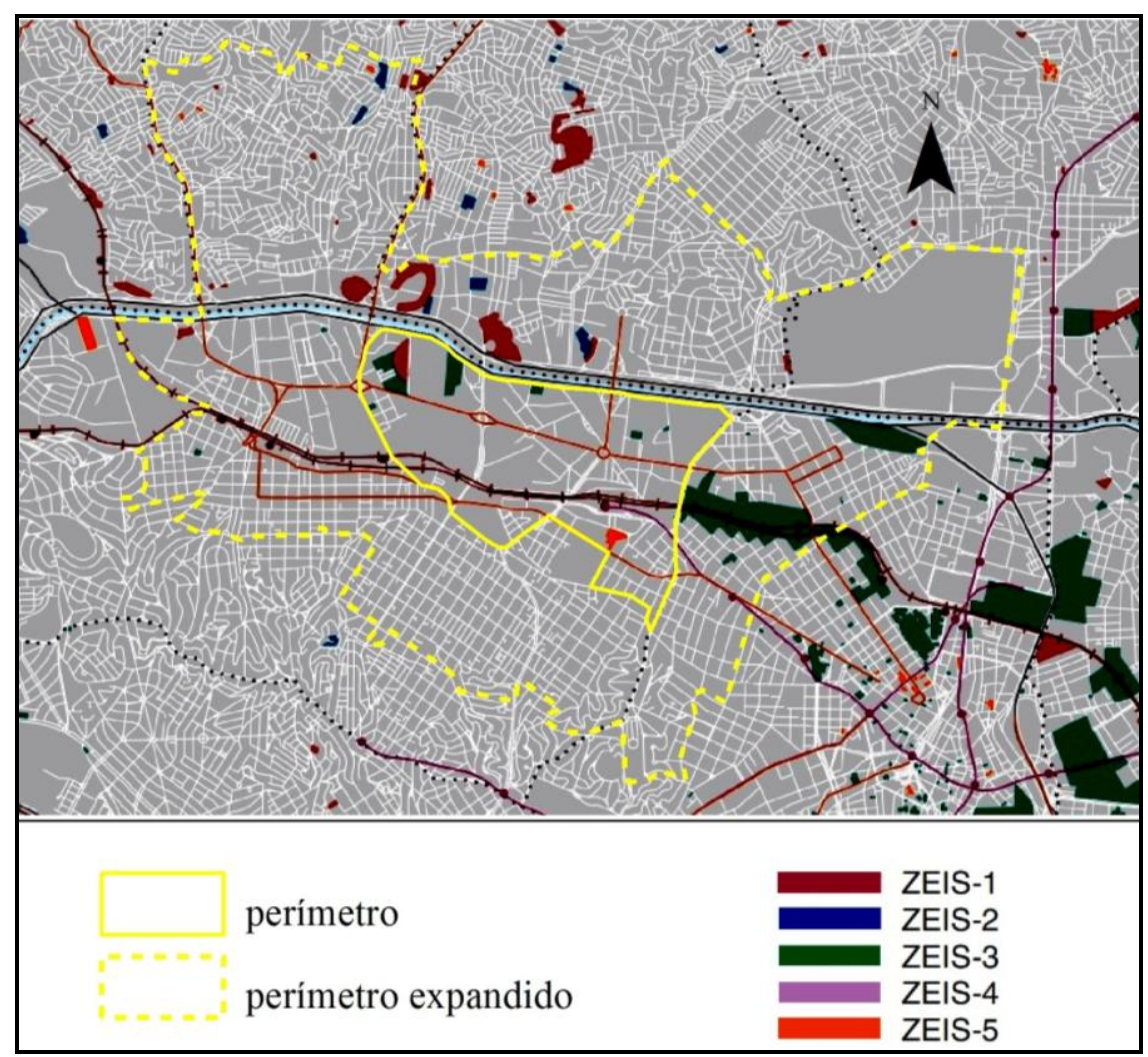

Figura 9 - Croqui ilustrativo do perímetro expandido da OUCAB e as ZEIS ${ }^{59}$ em seu interior. Fonte: Prefeitura Municipal de São Paulo ${ }^{60}$, 2014. Sem escala. Elaboração Própria

\footnotetext{
${ }^{59}$ A classificação de 1 a 5 das ZEIS que aparecem no croqui referem-se à porcentagem de investimentos que receberá para a Habitação de Interesse Social, a ZEIS-1 é a que mais receberá incentivo para esse tipo de moradia e a ZEIS-5 é a que menos receberá.
} 
A novidade é que os recursos originados dos CEPACs da OUCAB poderão se utilizados para Habitação de Interesse Social ${ }^{61}$, Habitação de Mercado Popular e reurbanização de favelas no perímetro expandido, alem de atendimento de transposições do rio Tietê, desapropriações necessárias e obras de drenagem.

Mostramos anteriormente que alguns especialistas criticavam as Operações Urbanas por utilizarem todo o recurso arrecadado com os CEPACs dentro de seu perímetro a despeito de carências encontradas por todo o território municipal, mas era o resultado de uma norma federal ${ }^{62}$. O que acabava por supervalorizar uma região em detrimento de outras áreas carentes, reforçando a segregação socioespacial da cidade.

c) Definição de no mínimo $15 \%$ dos recursos arrecadados direcionados para Habitação de Interesse Social (HIS) e reurbanização de favelas;

A lei de 1995 previa a construção de no máximo 630 unidades de HIS. Desta vez foi definido o mínimo, ou seja, não há limite máximo para construção de HIS, ou melhor, o limite será estipulado pelo Conselho Gestor.

d) Fica limitado o uso de apenas um andar de subsolo para estacionamento;

A medida faz parte das reivindicações de Ros Mari Zenha, conselheira do CADES, em função da observação da carta geotécnica da cidade, a OUCB está parcialmente inserida na várzea do rio Tiete e o uso do subsolo poderia comprometer o lençol freático.

e) Limite de uma vaga de estacionamento para cada $50 \mathrm{~m}^{2}$ de uso não residencial;

A medida visa incentivar o uso do transporte público.

f) Criação de um Grupo de Gestão;

O grupo deve ter dezesseis membros, sendo oito ligados ao Poder Público e oito da sociedade civil, que deverão deliberar sobre as prioridades no programa de intervenções. Garante-se a participação social não só no planejamento, mas também, na gestão do território extendendo, portanto, a operacionalidade do pluralismo jurídico.

\footnotetext{
${ }^{60}$ O perímetro expandido foi copiado da apresentação do Plano Urbanístico realizada pelos técnicos da SP Urbanismo em 2012. As ZEIS são aquelas expostas no Projeto de Lei do novo PDE (http://gestaourbana.prefeitura.sp.gov.br).

${ }^{61}$ Habitação de Interesse Social são unidades habitacionais direcionadas para famílias com renda inferior a seis salários mínimos.

${ }^{62}$ Estatuto da Cidade, 2001.
} 
Desta forma, a discussão sob o intermédio do Poder Executivo se encerra sob um debate até então mais restrito à área técnica, haja vista o número de reuniões técnicas (quinze) e apenas duas audiências públicas.

De certo que algumas alterações foram feitas, contudo, a sensação da falta de comunicação entre Poder Público e sociedade civil também é inequívoca. No Processo Administrativo constam várias solicitações de reuniões temáticas e de audiências públicas que não chegaram a acontecer.

Enquanto não se efetiva a lei da OUCAB, a lei vigente é a de 1995, por mais que as alterações agradem a sociedade civil, elas ainda não valem e o uso do território não espera a criação de uma norma jurídica, o uso se realiza.

\subsection{A discussão na Câmara Municipal de São Paulo}

Em dezembro de 2012, o prefeito Gilberto Kassab encaminhou o PL $\mathrm{n}^{\circ}$ 505/2012 à Câmara Municipal de São Paulo (CMSP), que aprovou o texto em primeira discussão em 09/04/2013 com apenas um voto contra. Entretanto, a “discussão" estava apenas começando.

Durante o período de encaminhamento do PL até sua primeira votação, a conselheira do CADES, por meio do blog do Movimento Água Branca, convidou os membros de associações de bairro e demais moradores da região da OUCAB para reuniões técnicas e temáticas com a finalidade de prepará-los para o debate na CMSP. Foi publicado no blog o PL ${ }^{\circ} 505 / 12$ e informações sobre os desdobramentos das reuniões técnicas, incluindo as atas, quando existiam.

O blog mencionado era o canal de comunicação entre a Conselheira do CADES, as associações de bairros, os Conselhos Comunitários de Segurança e moradores. O site do Movimento Água Branca dava agilidade às informações, já que eram disponibilizadas logo depois de reuniões importantes, e fortalecia o processo participativo, além da transparência que as lideranças transmitiam aos interessados.

A finalidade do blog se aproxima do objetivo do Diário Oficial do Município, que transmite as informações dos trabalhos da administração pública baseado no princípio da publicidade preconizado na Constituição Federal, isto é, dar transparência às iniciativas. $\mathrm{O}$ que queremos demonstrar com isso é que a sociedade civil observada nesta dissertação reproduz mecanismos parecidos ao do Estado para efetivar o pluralismo jurídico do tipo progressista, ou seja, comunitário-participativo como teorizamos no primeiro capítulo, item 1.2.2, ou seja, aquele modelo no qual o Estado 
deixa de decidir os conteúdos da lei transferindo este ato para que os diversos setores da sociedade o façam de acordo com seus interesses.

Mas, antes do relato da discussão na CMSP, vale uma breve explicação acerca do funcionamento do trâmite interno de um Projeto de Lei na casa legislativa.

O Projeto de Lei (PL), após ser proposto por um dos vereadores ou, neste caso, pelo prefeito, tramita pela CMSP conforme a Lei Orgânica do Município de São Paulo e o Regimento Interno da Câmara Municipal de São Paulo da seguinte forma:

a) O PL é lido no plenário para conhecimento de todos os vereadores;

b) O presidente da CMSP determina por quais das sete Comissões Permanentes ${ }^{63}$ existentes o PL deve ser apreciado;

c) Em seguida o PL deve entrar na pauta das votações, se for da vontade dos líderes partidários e do presidente;

d) No momento da primeira discussão, os vereadores podem encaminhar emendas e substitutivos ${ }^{64}$ que alteram o PL original;

e) Se o PL for aprovado em primeira votação, deverá aguardar pela segunda e definitiva votação;

f) Nesta fase os vereadores podem, ainda, encaminhar emendas e substitutivos;

g) Se aprovado em segunda votação, segue para ser sancionado pelo prefeito, que pode também, vetar parcial ou integralmente.

h) Se sancionado, o PL torna-se Lei após publicação em Diário Oficial do Município.

Lembramos que determinados temas, como a Operação Urbana Consorciada, obrigam que o PL seja discutido em Audiência Pública, para que a comunidade diretamente envolvida possa se manifestar e interferir na concepção da lei. É um processo, um rito de produção de normas pelo Estado em que sua participação diminui conforme aumenta a intervenção da sociedade civil.

\footnotetext{
${ }^{63}$ São elas: Comissão da Verdade; Comissão de Administração Pública; Comissão de Constituição, Justiça e Legislação Participativa; Comissão de Educação, Cultura e Esportes; Comissão de Finanças e Orçamento; Comissão de Política Urbana, Metropolitana e Meio Ambiente; Comissão de Saúde, Promoção Social, Trabalho e Mulher; Comissão de Trânsito, Transporte, Atividade Econômica, Turismo, Lazer e Gastronomia; Comissão Extraordinária Permanente de Defesa dos Direitos da Criança, do Adolescente e da Juventude; Comissão Extraordinária Permanente de Defesa dos Direitos Humanos, Cidadania e Relações Internacionais; Comissão Extraordinária Permanente de Meio Ambiente; Comissão Extraordinária Permanente de Segurança Pública; Comissão Extraordinária Permanente do Idoso e de Assistência Social.

${ }^{64} \mathrm{O}$ substitutivo é o nome que recebe o documento que substitui integralmente o PL, enquanto a emenda altera partes do PL.
} 
Desde o dia da primeira votação (09/04/2013) até a aprovação do PL em 15 de outubro do mesmo ano houve nove Audiências Públicas, algumas reuniões temáticas com a finalidade de qualificar a sociedade civil para o debate que se travaria na CMSP e trinta e duas emendas, das quais doze foram aprovadas. Após todo o debate a redação final do PL 505/12 seguiu para posterior sanção do prefeito, criando a Lei n ${ }^{\circ} 15.893$, de 07 de novembro de 2013.

O fato é que a aprovação em primeira votação conduziu o PL 505/12 para ampla discussão e diversos setores que não haviam se pronunciado durante a construção do PL no executivo, começaram a mostrar seus anseios, como veremos.

Em nossa primeira entrevista nesta etapa, apêndice $C$, conversamos com o único vereador que votou contrário à aprovação do PL n ${ }^{\circ}$ 505/2012.

$\mathrm{O}$ vereador justificou seu voto garantindo que pelo menos $50 \%$ dos vereadores recém-eleitos não conhece o PL n ${ }^{\circ}$ 505/2012, inclusive ele próprio. Além do mais, o vereador destacou que alguns parlamentares ficam atrelados com os segmentos que financiam suas campanhas, seja na área de transporte, seja no setor da construção civil, o que acaba por induzi-los a votarem a favor de seus interesses ${ }^{65}$.

A declaração do vereador demonstra que, diferente do debate no Executivo, a discussão na CMSP passa a ser menos técnica e mais política, isso parece justificar mais participação e mais conflitos nesta etapa do processo de revisão da lei em vigor. Consideramos que ambos os debates são imbuídos de ideologia, contudo, o saber técnico torna o diálogo mais restrito aos estudiosos do urbanismo, haja vista as solicitações de reuniões temáticas com linguagem mais acessível por parte dos moradores.

Vale ressaltar que a Comissão de Política Urbana, Metropolitana e Meio Ambiente $^{66}$, responsável por analisar o PL 505/12, tem como um dos sete membros, o

\footnotetext{
${ }^{65}$ De fato, verificamos junto ao Supremo Tribunal Eleitoral (TSE) que as empresas da construção civil e do setor imobiliário representam grande parcela dos doadores para campanhas eleitorais de 2012 dos diversos Partidos Políticos, com exceção dos novos Partidos Políticos que compõem a CMSP: Partido Social Democrático (PSD) e Partido Republicano da Ordem Social (PROS). No caso do Partido do Movimento Democrático Brasileiro (PMDB) constam 58 doações feitas por: "eleições 2012 Gabriel Benedito Isaac Chalita", em valores diversos, o que prejudicou a pesquisa, o Partido Popular Socialista (PPS) declarou doações da Direção Estadual do Partido e, por fim, o Partido Socialismo e Liberdade (PSOL) que entre seus doadores pessoas físicas há apenas um de pessoa jurídica, que é o próprio PSOL, com a doação de maior valor, quatro mil e duzentos reais. Disponível em: <http://inter01.tse.jus.br/spceweb.consulta.receitasdespesas2012/abrirTelaReceitasCandidato.action> Acesso em: 7 mar. 2014.

${ }^{66}$ A CMSP possui sete Comissões, que são colegiados de vereadores que analisam PLs por temas e emitem pareceres técnicos, conforme suas especificações.
} 
vereador Nabil Bonduki, professor titular do Departamento de Planejamento da Faculdade de Arquitetura e Urbanismo (FAU) da Universidade de São Paulo (USP), ou seja, a CMSP congrega o saber técnico com a política.

Setores da sociedade civil ficaram satisfeitos com a aprovação do PL em primeira discussão, entretanto desagradou a outros, como trataremos adiante.

Assim, na primeira Audiência Pública, em 16/05/2013, os diversos segmentos se posicionaram, a começar pelo presidente da Comissão, o vereador de oposição ao governo, Andrea Matarazzo, que, em dois momentos, se disse contra a OUCAB. Em entrevista com sua assessora, Asunción Blanco, apêndice D, ela informou que a oposição em relação à OUCAB se dá por conta da revisão do Plano Diretor, o que poderia causar conflitos ou distorções nas Leis.

Argumento esse que foi rebatido por Bonduki, mesmo partido do governo, que afirmou que enquanto não se alterasse a antiga lei da OUCAB, que é de 1995, ela seria mais perversa ao Plano Diretor da cidade, reafirmando que além de ser alterada, a lei deveria ser aprovada o mais rápido possível.

Ainda na primeira audiência púbica, a conselheira do CADES, Sra. Ros Mari Zenha, lembrou que algumas das alterações propostas nas reuniões técnicas foram incorporadas ao PL, contudo, havia algumas alterações que deveriam ser discutidas, entre elas: i) o número e os locais de implantação de equipamentos sociais como escolas e hospitais, considerando o adensamento proposto de mais de 60.000 habitantes; ii) um levantamento mais detalhado do inventário arquitetônico histórico e cultural; iii) garantia de locais destinados ao reassentamento para as famílias de baixa renda, principalmente para as famílias da favela do Sapo; iv) garantia de incorporação das áreas verdes ocupadas pelos clubes de futebol São Paulo e Palmeiras ao parque urbano previsto no Plano Urbanístico da OUCAB, atualmente ocupado pela Companhia de Engenharia de Tráfego (CET) e; v) estudo específico para obras de drenagem, considerando o Plano Diretor de Macrodrenagem da Bacia do Alto Tietê.

Aqui destacamos o mencionado ponto "iv" do parágrafo acima. No item anterior citamos a desapropriação da favela do Sapo e o questionamento feito pelas famílias desapropriadas e pela conselheira do CADES acerca das áreas públicas ocupadas pelos clubes de futebol em caráter de concessão. Lembramos que, o que foi questionado era a concessão de uso com a finalidade esportiva em detrimento do direito de moradia preconizado na Constituição Federal. Indagação, aliás, que nunca foi respondida. 
Entretanto, segundo a Sra. Zenha, que solicitou que nenhum Projeto de Lei direcionado ao perímetro da OUCAB fosse votado sem ser discutido com a sociedade civil, foi informada por dois dos vereadores da Comissão de Política Urbana que, o vereador Marco Aurélio da Cunha, do Partido Social Democrático (PSD), propunha a ampliação do prazo para a concessão de uso do Centro de Treinamento do São Paulo Futebol Clube. Destacamos que o vereador, com interesse na ampliação do prazo de concessão, foi dirigente do citado clube.

Zenha afirma que lideranças da sociedade civil com o apoio dos vereadores Bonduki, Partido dos Trabalhadores (PT), e Paulo Frange, Partido Trabalhista Brasileiro (PTB), conseguiram suspender o assunto em pauta até o debate final da OUCAB. Notase claramente a complexidade das relações sociais e o papel da norma no uso do território, portanto, sua elaboração (da norma) é sujeita ao confronto de vários agentes.

$\mathrm{Na}$ visão da urbanista Lacreta, diretora da associação Defenda São Paulo e conselheira da Comissão de Política Urbana das subprefeituras de Pinheiros, Lapa e Butantã, o PL enviado à CMSP não contempla o Plano Urbanístico e a operacionalidade da nova lei vai depender do interesse do mercado imobiliário.

Lacreta demonstra que até a data da primeira audiência, apenas $7 \%$ dos recursos arrecadados foram utilizados, ou seja, a lei precisa ser coerente com o Plano Urbanístico e com os estudos econômicos, para isso tem que estar na norma como, quando e onde o dinheiro arrecadado será gasto.

Os apontamentos da urbanista focaram também: i) a ausência de equipamentos sociais no perímetro; ii) o baixo valor do CEPAC, que corresponde a $10 \%$ do valor do metro quadrado na região; iii) a garantia de que $15 \%$ da arrecadação vão dar conta de construir moradias no perímetro expandido; iv) a previsão de áreas verdes no perímetro, 3,6 m², são bem inferiores aos $12 \mathrm{~m}^{2}$ sugeridos pela Organização Mundial da Saúde e o $8 \mathrm{~m}^{2}$ sugeridos pelo Instituto Brasileiro do Meio Ambiente e dos Recursos Naturais Renováveis (IBAMA).

Em contrapartida, outro importante interlocutor, o Sindicato de Empresas de Compra, Venda, Locação e Administração de Imóveis Residenciais e Comerciais de São Paulo (SECOVI), representante do mercado imobiliário, tomou o seguinte posicionamento na Audiência Pública em relação a alguns aspectos: 
a) Ressaltou a falta de clareza sobre a construção de Habitação de Interesse Social (HIS), a implantação de equipamentos sociais, obras de melhoramento em infraestrutura e de incentivo ao transporte público;

b) Afirmou que a taxa mínima (30\%) de permeabilidade é ineficaz em áreas de várzea e que devem ser substituídas por caixas de retenção;

c) Solicitou o uso de mais de um subsolo para estacionamento dos novos edifícios.

Em entrevista, o Sr. Della Manna, representante do SECOVI, informou que o PL enviado à CMSP não contemplava seus anseios e que a discussão nas novas audiências públicas era fundamental. Os itens "b" e "c" acima foram os mais criticados pelas associações de moradores.

Contudo, Sr. Della Manna explicou, ainda em entrevista, que é exagerado culpar o mercado imobiliário pelo uso desmedido do automóvel. Não é limitando o número de vagas de estacionamento que o uso do automóvel será reduzido, seu uso é incentivado de várias formas: i) há incentivos fiscais como redução de impostos; ii) financiamento em longo prazo para a compra do automóvel; c) obras viárias como o rodoanel e ampliação da marginal Tietê; d) pouco investimento em transporte público.

Ademais, o número de vagas para automóveis é um dos principais atrativos para a compra de um imóvel e se o mercado imobiliário não buscar alternativas para a aceleração das vendas, a OUCAB fica comprometida.

Mais uma vez verificamos que um imbricado sistema normativo aliado ao sistema de objetos impõe um uso específico do território e que para possibilitar um novo uso é necessário mais do que normas locais. Nesse caso, implicaria um confronto com a indústria automobilística que atua em escala global - a influência do externo. Mas, não nos estenderemos nesse assunto para não correr o risco de comprometer nosso objetivo.

Ao final da primeira audiência pública, vinte e sete representantes das comunidades foram ouvidos, podemos dividi-los em dois grupos de moradores: $1^{\circ}$, os do perímetro e, $2^{\circ}$, os do perímetro expandido.

$\mathrm{O}$ primeiro dos dois grupos reivindicou predominantemente escolas, creches e postos de saúde, enquanto o segundo grupo questionou os $15 \%$ destinados à Habitação de Interesse Social (HIS), que acreditam ser pouco e querem entender o que será feito com o restante dos recursos arrecadados. 
No mês de maio de 2013 houve ainda mais duas audiências públicas, nas quais mais um agente relevante se manifestou, a Associação Brasileira dos Escritórios de Arquitetura (AsBea). A observação polêmica da Asbea foi sobre a redução do número máximo de vagas de automóveis, da qual se posicionaram contra utilizando os mesmos argumentos do representante do SECOVI ${ }^{67}$.

No começo de junho, os vereadores juntaram ao Processo Administrativo de que trata o PL da OUCAB uma resposta aos questionamentos feitos durante as audiências públicas (Anexo $\mathrm{B}^{68}$ ). No documento evidenciamos os pontos a seguir:

a) A Prefeitura de São Paulo, na qualidade de empreendedor, garante a reserva de terrenos para a construção de 1500 a 2000 unidades de Habitação de Interesse Social (HIS) dentro do perímetro e quantidade mínima de atendimento ao perímetro expandido, totalizando 4000 unidades;

b) Obras de drenagem pluvial com recursos da OUCAB devem sair do perímetro, considerando assim a bacia hidrográfica como um todo;

c) A prorrogação ou não da concessão de áreas dos clubes Palmeiras e São Paulo ficará por conta da CMSP;

d) Sobre os equipamentos públicos, o estudo de adensamento indica a necessidade de 17 equipamentos de educação e 3 equipamentos de saúde. Quanto às áreas de lazer e esporte foi indicada a necessidade de, no mínimo, $264.000 \mathrm{~m}^{2}$ de terreno, sendo que o plano de melhoramentos públicos reserva o equivalente a $320.000 \mathrm{~m}^{2}$ de novas áreas verdes.

Em relação aos equipamentos públicos tanto o PL como o Plano Urbanístico não identificam as áreas de implantação.

Desta forma, a participação social, no que se refere aos moradores da região, foi aumentando, bem como o interesse dos vereadores em contribuir com seus anseios. Uma grande diferença entre os técnicos do Executivo que licenciaram o empreendimento e os vereadores que irão entregar a lei da OUCAB finalizada ao prefeito, é que os primeiros são funcionários de carreira, os vereadores são representantes do povo por meio do voto. Isso muda significativamente seus diálogos com a sociedade civil.

\footnotetext{
${ }^{67}$ Sobretudo quanto a real situação da rede de transporte público em relação à demanda de adensamento proposto.

${ }^{68}$ Este é um documento que resume os questionamentos, acompanhados das respectivas respostas e inclui a relação dos grupos organizados da sociedade civil que solicitaram tais explicações.
} 
Vejamos o caso de um dos vereadores, quando em entrevista (Apêndice E) foi indagado sobre o porquê que a sociedade civil considerava mais os técnicos do executivo e o Ministério Público como aliados e não o legislativo; sua resposta foi categórica:

Você tem que perguntar para eles e você vem aqui me perguntar. [...]. Todos esses que não recorrem à gente, eles vão às urnas, talvez tenham que fazer uma reflexão sobre isso, mas é uma reflexão deles, a gente vai continuar aqui oferecendo nossos estudos, nossos trabalhos. Quem sabe se eles tivessem uma rotina de vir mais aqui, como eles vão ao Ministério Público eles teriam uma visão da Câmara igual a que eles têm do Ministério Público. (2013)

$\mathrm{Na}$ resposta, o vereador dá a entender que o povo deve procurá-los rotineiramente. Entretanto, diante da articulação dos agentes sociais, moradores das comunidades mais pobres da região, o vereador decidiu não só convidá-los a ter uma rotina de ir à CMSP como também foi pessoalmente até a comunidade. $\mathrm{O}$ encontro ocorreu no dia 26 de junho de 2013 no auditório da CET, na Avenida Marques de São Vicente, foto 07 , onde a comunidade apresentou suas demandas e preocupações. $\mathrm{O}$ vereador concluiu: "foi a melhor audiência pública sobre o PL 505/2012"69.

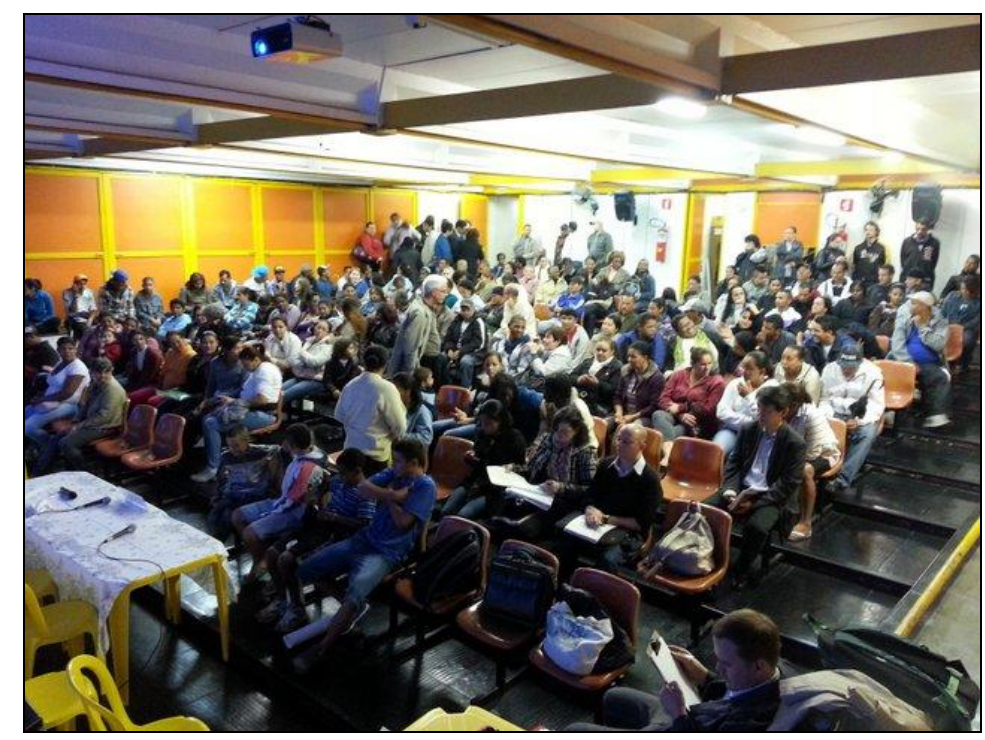

Foto 7 - Auditório da CET, onde foi realizada a audiência pública com presença marcante dos moradores da comunidade da Vila Chalot. Fonte: Movimento Água Branca ${ }^{70}, 2013$.

\footnotetext{
69 Disponível em: <http://movimentoaguabrancasp.blogspot.com.br/2013/06/com-palavra-osasmoradoresas-da-agua.html> Acesso em: 22 fev. 2014.

${ }^{70}$ Disponível em: <http://movimentoaguabrancasp.blogspot.com.br/2013_06_01_archive.html> Acesso em: 25 mar. 2014.
} 
Como resultado dessas audiências públicas, os vereadores da Comissão de Política Urbana marcaram uma vistoria no setor em que se localiza o Conjunto Habitacional Água Branca para conhecer os problemas levantados pelos moradores.

$\mathrm{Na}$ vistoria realizada no começo de julho, fotos 08 e 09 a seguir, foram levantados problemas de estrutura nos prédios da comunidade, ausência de equipamentos públicos de saúde, educação, lazer, segurança, foi falado sobre a desapropriação da favela do Sapo e a falta de moradia das famílias removidas, além dos problemas de enchente e da falta de limpeza no córrego da Água Branca.

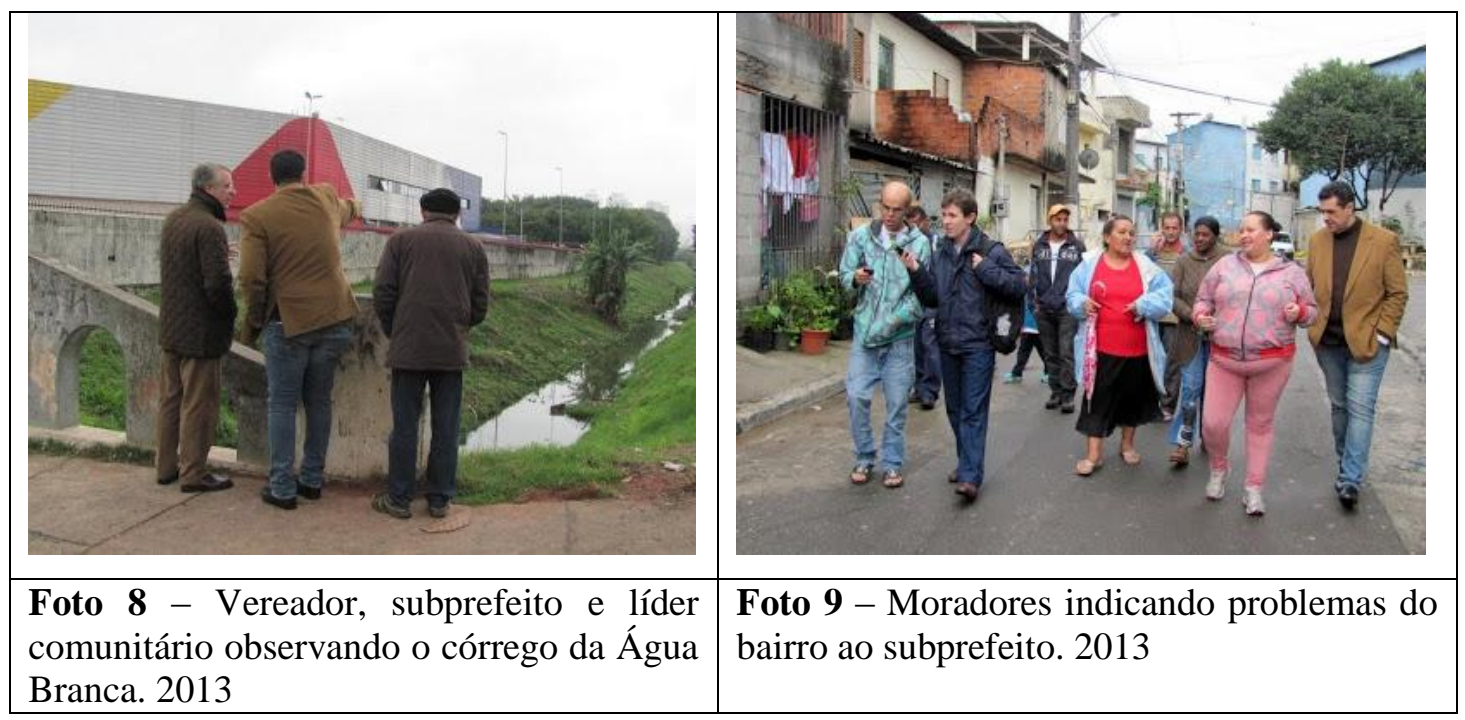

As informações coletadas eram fundamentais para a elaboração do substitutivo que a Comissão de Política Urbana estava preparando.

No dia seguinte, 27 de junho, houve outra audiência pública, desta vez na CMSP, na qual, entre outros aspectos, foram apontadas as questões dos moradores da comunidade Água Branca que seriam incorporadas ao substitutivo do Projeto de Lei (PL). As principais são:

a) Incluir as cabeceiras dos córregos Água Preta e Sumaré ao perímetro expandido;

b) Segregar os recursos arrecadados pela lei de 1995, garantindo que sejam aplicados em projetos conhecidos pela população, por exemplo, obras de drenagem nos córregos Sumaré, Água Preta, Água Branca, Quirino dos Santos e Pacaembu (os cinco córregos inseridos no perímetro da OUCAB), melhoramento viário e reforma nos prédios do conjunto Água Branca;

c) Destinação de $30 \%$ para HIS.

Crescia, portanto, a participação da população moradora na elaboração da norma jurídica, sobretudo a população de baixa renda. A efetivação de sua demanda seria 
fortalecida com a presença do Ministério Público do Estado de São Paulo na audiência do dia 27 de junho, acionado pela conselheira do CADES e pela diretora da associação Defenda São Paulo.

O Promotor de Justiça fez diversas considerações e recomendações durante o encontro e dias depois, por intermédio de ação civil pública, conseguiu bloquear os recursos arrecadados pela lei da OUAB de 1995. O objetivo do Ministério Público foi atender as denúncias de que as obras de infraestrutura que deveriam ocorrer no perímetro da OUCAB nunca aconteceram.

A efetivação da demanda dos moradores da região da OUCAB, neste caso, não se deu pelo Executivo, tampouco pelo Legislativo, mas, pelo Judiciário. Constata-se que a comunidade pleiteia maior autonomia perante o Estado, mas, recorre ao próprio Estado para solicitar a efetivação de seus direitos, o que coloca em conflito o mesmo sujeito social, como explica Bobbio $(2011,51)$ :

[...] Esses dois processos representam bem as duas figuras do cidadão participante e do cidadão protegido que estão em conflito entre si às vezes na mesma pessoa: do cidadão que através da participação ativa exige sempre maior proteção do Estado e através da exigência de proteção reforça aquele mesmo Estado [...].

Entretanto, a mesma ambiguidade pode ser atribuída ao Estado, que, em relação à sociedade civil, emancipa e protege ao mesmo tempo.

Logo após esse desfecho, no mês de julho de 2013, foi aprovado um empreendimento de grande porte no perímetro da $\mathrm{OUCAB}$, sem a consulta à sociedade civil. Isto porque a lei vigente, que era de 1995 não previa a consulta pública.

Trata-se de um projeto da construção de duas torres comerciais no terreno do antigo parque de diversões Playcenter na Barra Funda, localizado no setor G, junto à Marginal Tietê. Do empreendimento resultou uma contrapartida de aproximadamente 40 milhões de reais a ser somado com os 350 milhões depositados no fundo da OUAB, que acabara de ser bloqueada pelo Ministério Público.

A preocupação dos líderes do Movimento Água Branca é que o empreendimento não seguirá as regras da nova OUCAB. Verificamos então que se a comunidade local se organiza e alcança alguns de seus objetivos, o setor imobiliário também está ativo e realizando seus interesses.

O confronto entre os setores foram se acirrando e a busca por maior participação foi crescendo. A audiência pública marcada para agosto de 2013, no auditório a 
Universidade Nove de Julho, que fica dentro do perímetro da OUCAB foi cancelada por causa do excesso de pessoas que compareceram ao local.

Segundo informações do Movimento Água Branca, o local comportava trezentas pessoas e compareceram mais de mil. Outra audiência pública aconteceu no mesmo local no dia 18 de agosto de 2013, na qual foi apresentado o substitutivo do PL 505/12, isto é, o novo Projeto de Lei (PL) elaborado pelos vereadores da Comissão de Política Urbana da CMSP com base nas demandas dos setores da sociedade civil e que substitui o texto apresentado pelo Executivo.

A intenção dessa audiência era apresentar o que foi alterado no PL que iria para segunda e definitiva votação no plenário. As principais alterações foram:

a) A definição do perímetro expandido com inclusão das cabeceiras dos córregos Água Preta e Sumaré;

b) A criação de três contas bancárias, duas para os recursos da OUAB de 1995, sendo uma destinada para a construção de 630 unidades habitacionais com prioridade para as famílias desapropriadas da favela do Sapo e da Aldeinha $^{71}$, a outra para as obras de drenagem previstas e a terceira conta para os recursos da venda dos CEPACs da nova OUCAB;

c) Reforma e requalificação do conjunto Água Branca;

Essas três primeiras alterações foram demandas da própria comunidade durante as audiências públicas e de vistora dos vereadores na vizinhança da Vila Chalot. Continuando:

d) Aquisição de terras para a construção de Habitação de Interesse Social (HIS) no perímetro da OUCAB e em seu perímetro expandido, visando ao atendimento de 5.000 famílias;

e) Foi definida a quantia de equipamentos públicos sociais: implantação de no mínimo dez centros de educação infantil, duas escolas municipais de educação infantil, quatro escolas municipais de ensino fundamental, uma escola de ensino médio, duas unidades básicas de saúde e uma unidade básica de saúde com assistência médica ambulatorial;

f) Aumentou de $15 \%$ para $25 \%$ o total dos recursos arrecadados com a venda dos CEPACs para HIS sendo que 35\% deste valor serão para aquisição de terras e o restante para construção;

\footnotetext{
${ }^{71}$ A favela da Aldeinha foi totalmente removida antes do início desta pesquisa, muitas das famílias que lá moravam, migraram para a favela do Sapo, o restante se espalhou pela cidade.
} 
g) Os recursos utilizados no perímetro expandido serão direcionados exclusivamente para HIS, obras de drenagem e transposição do rio Tietê com vistas ao transporte não motorizado.

Com isso, um trabalho que se iniciara em 2007, chegava ao fim. Muitas das demandas da população moradora na região foram incorporadas. Mas, um substitutivo enviado pelo executivo às vésperas de sua votação causou revolta nos movimentos sociais, incluindo a conselheira do CADES, por atender as demandas do mercado imobiliário.

O substitutivo foi apresentado em outubro de $2013 \mathrm{com}$ as seguintes e principais alterações:

a) $\mathrm{O}$ atendimento mínimo de reassentamento de população de baixa renda diminuiu de 5.000 para 3.000 famílias (artigo 9);

b) Dos recursos arrecadados, "25\% no mínimo" seria para Habitação de Interesse Social, agora será 20\%, sem mínimo (artigo 12);

c) Implantação de corredores de ônibus ligando o lado norte do rio Tietê por meio de ponte, incluindo desapropriações necessárias. Antes, o recurso seria usado no perímetro expandido apenas para obras de drenagem e moradia. (artigo 13);

d) Aumento do número de vagas para as unidades habitacionais de $50 \mathrm{~m}^{2}$, onde se estabelecia uma ou duas vagas, passou a três (artigo 26);

e) Passou a ser admitido o segundo subsolo para estacionamento, antes vedado por se tratar de área de várzea (artigo 37);

f) Acrescentou-se três moradores do perímetro expandido para participar do Conselho Gestor, grupo que votará pelas prioridades das obras que serão realizadas com os recursos dos CEPACs (artigo 61);

g) Antes, qualquer empreendimento protocolado até a data da expedição do alvará de licença ambiental deveria fazê-lo conforme a lei de 1995. Agora, qualquer empreendimento protocolado até a data da publicação da nova lei da OUCAB, deverá fazê-lo conforme lei anterior, menos restritiva.

$\mathrm{Na}$ audiência pública, na qual o substitutivo do Projeto de Lei foi apresentado, o representante da SP Urbanismo, empresa pública responsável pelo plano urbanístico da OUCAB, justificou as principais alterações: i) o uso do segundo subsolo informando que a tecnologia de engenharia atual permite que isso se faça sem ter que bombear, ou 
seja, retirar a água do lençol freático; ii) o aumento de gabarito de $42 \mathrm{~m}$ para $80 \mathrm{~m}$ nos edifícios fora dos eixos de verticalização não muda o coeficiente de aproveitamento do lote, ou seja, a construção terá o mesmo adensamento construtivo, em vez de ocupar todo o terreno do lote, ocupa uma parte menor e verticaliza, mas com mesmo $\mathrm{m}^{2}$ total.

Em relação à transposição do rio, isto é, da implantação de uma ponte, o Sr. Weber Sutti da SP Urbanismo diz que nada adianta requalificar uma porção do território da cidade se não há melhoria de acesso a ela.

Ainda em relação à ponte, ressaltamos que um dos vereadores, integrante da Comissão de Política Urbana, manteve contato com um dos líderes da comunidade de Pirituba durante a audiência pública. Em sua página da internet ${ }^{72}$, o vereador em tela, afirma que aproveitou o momento para trazer para a audiência pública a comunidade da zona noroeste da cidade a fim de sensibilizar os demais vereadores e o prefeito para o atendimento da solicitação de uma ponte facilitando o acesso da região ao centro da cidade. Vejamos o texto de seu site eletrônico:

Depois de mais de seis meses de amplas discussões, o projeto foi aprimorado e a área ampliada para contemplar a Ponte de Pirituba. Ao final, foram 76 artigos em 56 páginas, mais anexos, quadros e plantas, dissecados por Frange, que viu a possibilidade de incluir Pirituba como beneficiária dos recursos que serão arrecadados pela Operação Urbana Consorciada Água Branca. (http://www.paulofrange.com.br/noticias_237.html, 2013)

O fato é que a notícia da inserção da ponte no plano urbanístico deixou os participantes surpresos e indignados. A começar pelos próprios vereadores. Um dos vereadores de oposição dizia que a CMSP neste caso foi afrontada pelo executivo, que apresentou um substitutivo alterando pontos significativos do PL. Em contrapartida, o vereador da situação informou que as alterações foram discutidas nas audiências públicas e que representam as demandas protocoladas por setores da sociedade civil, entre eles o Sindicato das Empresas de Compra, Venda, Locação e Administração de Imóveis Residenciais e Comerciais de São Paulo (Secovi) e da Associação Brasileira dos Escritórios de Arquitetura (AsBea).

Nós mostramos ainda neste capítulo que este era, realmente, o posicionamento do Secovi em relação ao aumento do subsolo.

Os participantes da audiência pública se posicionaram, de maneira geral, da seguinte forma:

\footnotetext{
${ }^{72}$ Disponível em: <http://www.paulofrange.com.br/noticias_237.html> Acesso em: 16 mai. 2014.
} 
a) Os técnicos (urbanistas, geógrafos, engenheiros) representantes de entidades sociais fizeram questão que constasse na ata que o que estava sendo apresentado neste dia, este "novo" plano urbanístico deveria ser submetido a outro estudo de impacto ambiental e consequentemente outro processo de licenciamento, incluindo novas audiências públicas;

b) Foi causado grande desconforto entre as comunidades dos lados norte e sul do rio Tietê. Do lado sul reclamaram que para implantar a ponte tiveram que diminuir o número de HIS. Do lado norte, disseram que a ponte é uma solicitação antiga e que eles eram esquecidos e isolados do outro lado do rio e que uma Operação Urbana deve ser benéfica para a cidade toda e não só para uma parte.

Diante do tumulto gerado, os vereadores marcaram a última audiência pública para a semana seguinte (07/10/2013). Nessa última audiência não houve consenso nem novas alterações do conteúdo do PL, entretanto, não dispomos de seu registro escrito. Entramos em contato com a ouvidoria da CMSP, mas responderam que não houve audiência sobre a OUCAB naquela semana. Por algum motivo, não quiseram disponibilizar o conteúdo da reunião, que não consta também do Processo administrativo, assim como as demais atas. Depois, foi-nos informado pela assessoria de um vereador que nem todas as audiências públicas são transcritas.

No dia seguinte, 08 de outubro de 2013, foram negociadas, na CMSP, 32 emendas ao Projeto de Lei (PL) 505/2012, das quais 12 foram aprovadas. O PL foi enviado para a sanção do prefeito sem que a sociedade civil soubesse quais as alterações propostas pelas 12 emendas.

Entre as mudanças, destacamos a alteração de $20 \%$ para $22 \%$ dos recursos arrecadados para HIS, resultado das pressões da sociedade civil. O restante dizia respeito a pequenas mudanças no sistema viário ${ }^{73}$.

Ao fim desta fase, o principal movimento social da região, o Movimento Água Branca, dizia que o processo democrático havia sido desrespeitado ao incluírem na lei propostas que não foram debatidas ${ }^{74}$. Para o Movimento Nacional de Moradia Popular, a lei não atende aos pobres e para a urbanista Lacreta do Movimento Defenda São

\footnotetext{
${ }^{73}$ Conteúdo verificado no Processo Administrativo no $01-505$ de 2012, que trata do trâmite do Projeto de Lei 505/2012 referente à Operação Urbana Consorciada Água Branca (OUCAB) na Câmara Municipal de São Paulo.

${ }^{74}$ Conteúdo disponível em: <http://movimentoaguabrancasp.blogspot.com.br/2013/10/podem-fazer-como-pl-do-plano-diretor-o.html> Acesso em: 28 mai. 2014.
} 
Paulo, a nova lei contraria a licença ambiental, adicionando obras, cujos impactos não foram considerados ${ }^{75}$.

Quanto aos vereadores da Comissão de Política Urbana, eles se mostraram contra a alteração de gabarito dos edifícios de $40 \mathrm{~m}$ para $80 \mathrm{~m}$ de altura, contra o segundo subsolo e contra o aumento para três vagas de automóveis para apartamentos de $50 \mathrm{~m}^{2}$. Mas, consideraram que a lei avançou em relação às outras Operações Urbanas. E divergiram em alguns aspectos, enquanto um vereador foi contra a incorporação do perímetro expandido, outro comemorou por poder construir uma ponte de transposição do rio, beneficiando os moradores da zona norte da cidade.

O conselho gestor, responsável pela gestão dos recursos e a definição de quais serão as obras prioritárias, foi constituído no dia 05 de maio de 2014 . O grupo é composto por nove pessoas do Poder Público e nove da sociedade civil, entre eles moradores eleitos pela comunidade, um representante do Secovi (setor imobiliário) e técnicos ligados à área acadêmica.

Segundo informações no site do Movimento Água Branca, que continua ativo e prestando serviço à comunidade, o grupo gestor se reuniu duas vezes para estudar a lei e aguarda ansiosamente a primeira reunião com a SP Urbanismo, pois há demandas urgentes que dependem do estabelecimento das prioridades.

Assim, qualquer empreendimento proposto já deve ser submetido à lei recémcriada e à compra de CEPAC, liberando os recursos para a ação do conselho gestor. Certamente, que as prioridades escolhidas serão debatidas, ainda, sob o conflito dos desejos contraditórios, considerando a pluralidade dos agentes integrantes no conselho gestor. Mas, para que os resultados continuem equilibrados, é fundamental que os trabalhos do conselho sejam transparentes e discutidos com os envolvidos (moradores e pessoas que frequentem o lugar) por meio de reuniões de caráter consultivo.

Com a diversidade de agentes, o processo de pluralismo jurídico foi intensificado, evidenciando a complexidade do uso do território. O processo ocorrido na Câmara Municipal de São Paulo nos leva a compreender o papel fundamental da norma; pois, por meio desse processo, foi-nos permitido ver como o sistema normativo atrelado ao sistema de objetos faz do território usado uma instância social.

\footnotetext{
75 Conteúdo disponível em: <http://www.redebrasilatual.com.br/cidadania/2013/10/ministerio-publicotomara-medidas-judiciais-contra-operacao-urbana-agua-branca-na-zona-oeste-de-sp-9826.html> Acesso em: 28 mai. 2014.
} 


\section{CONSIDERAÇÕES FINAIS}

Considerando a perspectiva do território usado, compreendido como o conjunto de formas somado as ações que recaem sobre as formas (Santos, 2005), a OUCAB nos permitiu observar uma acirrada e equilibrada correlação de forças entre os setores da sociedade civil, identificados em três principais grupos: i) os moradores do interior do perímetro da OUCAB; ii) os moradores do perímetro expandido; iii) e o setor imobiliário.

A conflituosa relação verificada obtém importância em nossa pesquisa quando associamos à perspectiva da norma, considerada em três conjuntos distintos, mas complementares (Mendes Jr., 2005): a norma dos objetos técnicos; a norma das ações sobre os objetos; e a norma jurídica, que restringe as ações sobre os objetos técnicos. Isto porque, a regulação imposta pela norma, seja qual for das três mencionadas, pode dar mais liberdade a determinado agente social, enquanto restringe a liberdade de outro.

Quando demonstramos o território do perímetro da OUCAB como herança, estamos percebendo o território, as formas, ou seja, os objetos técnicos como norma. A interação entre o velho e o novo se dá em função do sistema técnico industrial mencionado no capítulo 1 e retomado no capítulo 2 com destaque à ferrovia e às fábricas. A regulação neste caso restringe o uso habitacional, o que resultou no vazio demográfico verificado no mapa 1. Além disso, verificamos o resultado não visível do uso industrial pretérito, a contaminação do solo. Duas consequências, das quais a primeira estimularia ações futuras culminando na OUCAB e a segunda, a contaminação do solo, resultaria em leis estadual e municipal que regulam seu gerenciamento, despertou dúvidas sobre as consequências para os moradores e causou ônus para os construtores, que devem remediá-la.

Assim, as interações entre o velho e o novo, isto é, as relações entre as formas do passado e as ações do presente, se revelam por meio da técnica e da norma, do sistema de objetos e do sistema de ações e demandam a criação de um plano urbanístico visando à mudança no uso do território.

As ações, objetivando o distrito da Barra Funda, tiveram dois momentos distintos: o primeiro quando impactado com o deslocamento industrial ocorrido em um novo período técnico baseado no transporte rodoviário, quando a partir de então passa a ser alvo de novas necessidades, quais sejam, transformarem o espaço urbano dotado de 
infraestrutura e desprezado pelos industriais em um polo de serviços por meio da promoção imobiliária, convergindo, assim, com os desejos dos agentes hegemônicos. Nesse momento em que a participação social não era obrigatória, o Poder Público municipal criou em 1995 a Operação Urbana Água Branca (OUAB).

Para induzir a ocupação esperada, a prefeitura disponibilizou $900.000 \mathrm{~m}^{2}$, além do permitido pelo zoneamento da cidade, para a construção de edifícios comerciais e $300.000 \mathrm{~m}^{2}$ para uso residencial.

Como a procura pelo uso residencial foi maior, a OUAB não atingiu seu objetivo. Simultaneamente, a gestão pública das cidades passava a adotar uma postura de empreendedorismo urbano baseada na Parceria Público-Privada (PPP) e no planejamento estratégico.

A postura descrita acima, alinhada com a política neoliberal, era apresentada por urbanistas europeus $^{76}$ e denotava o acionamento da regulação híbrida do território ${ }^{77}$ a partir de outro continente, mas, que vinha ao encontro dos interesses dos agentes hegemônicos no Brasil do ramo da construção civil, que têm na PPP, segundo Vainer (2009), uma maneira legítima de participar no planejamento e gestão territorial.

Os anseios por maior participação nas políticas urbanas por parte dos empreendedores e da sociedade civil, como apresentamos em Maricato (2008) resultaram em mudanças na política urbana brasileira. Foi estabelecido o Estatuto da Cidade em 2001, Lei federal que dispõe sobre a regulação da política urbana local com relevo à participação da sociedade civil. A legislação municipal de São Paulo incorporou os princípios da Lei federal.

Assim, com as novas diretrizes para as cidades e com a realidade do município de São Paulo, isto é, um novo período técnico pautado no rodoviarismo e na verticalização, a OUAB precisou ser reformulada para se transformar na Operação Urbana Consorciada Água Branca (OUCAB), mas dessa vez, com a participação de todos os setores da sociedade civil.

Ressaltamos, nesse contexto, a interação entre o interno e o externo, considerando ainda que o empreendedorismo urbano como fator externo regulando a maneira de pensar o planejamento urbano brasileiro contribuiu com a formulação das

\footnotetext{
${ }^{76}$ Referimo-nos aos urbanistas catalães, que durante a Conferência das Nações Unidas para os Assentamentos Humanos da ONU, 1996, reforçaram a importância do Planejamento Estratégico para as cidades no seu papel de combate à desigualdade social e ambiental. O modelo foi copiado por cidades da América Latina.

${ }^{77}$ Termo utilizado por Antas Jr. para se referir ao pluralismo jurídico com vistas ao território.
} 
Operações Urbanas Consorciadas. Contudo, demonstramos que cada uma delas efetivadas na capital paulista teve objetivos e consequências diferentes, em arrecadação de recursos e em exclusão social, levando em conta os fatores internos serem igualmente diferentes, pois enquanto o objetivo principal das OUCs anteriores era a reestruturação viária, a OUCAB tinha uma proposta mais complexa de adensamento habitacional, o que demandava por equipamentos sociais.

A OUCAB surge, portanto, no bojo do processo de reestruturação urbana. $\mathrm{O}$ objetivo, fundamentado no empreendedorismo urbano, de estimular os usos mistos, isto é, edifícios com usos comerciais, de serviços e residenciais, pretende diminuir os deslocamentos, cada vez mais difíceis, dentro da cidade.

Avaliamos que a disputa na construção de uma lei que seja favorável aos interesses de determinado grupo social, na política urbana, foi intensificada pelas exigências de participação da sociedade civil na elaboração da norma jurídica preconizada no Estatuto da Cidade. Exigência feita tanto para a elaboração de Planos Diretores como para a utilização de instrumentos como a Operação Urbana Consorciada.

A obrigação da participação social confirma o processo de procedimentalização apontado por Faria (2011), no qual o Estado se isenta da decisão sobre o conteúdo da lei, função que é transferida aos diferentes setores da sociedade civil, que operam de acordo com suas necessidades e desejos. Desta forma, emerge o pluralismo jurídico, princípio em que o Estado não é o único produtor de normas, como vimos em Santos (1979), Faria (2011) e Wolkmer (2001).

A Prefeitura do Município de São Paulo (PMSP), por sua vez, solicita à empresa pública SP Urbanismo um novo plano urbanístico, agora com acréscimo de estoque de área destinada à construção de imóveis residenciais.

Anunciada a mudança, a valorização imobiliária que vinha ocorrendo recebe novo impulso como o observado, por exemplo, no empreendimento "Jardim das Perdizes", (Anexo A). Considerando que a OUCAB é eminentemente dependente do mercado imobiliário para sua realização, o Poder Público investe no local contribuindo para sua valorização.

Entretanto, conforme expomos, os investimentos públicos com finalidade de valorização foram direcionados para projetos que sejam atrativos aos investidores imobiliários, entre eles a Fábrica dos Sonhos, em detrimento de setores carentes e mais 
urgentes para a população moradora como drenagem urbana e equipamentos sociais de saúde e de educação.

Aliás, os projetos urbanos que têm por característica primeira tornar o território atrativo ao investidor imobiliário, tornam-se agravantes aos moradores porque desviam recursos públicos para investimentos em obras viárias que não resolvem seus problemas mais urgentes e são tratados fora do plano urbanístico da OUCAB com estudos específicos de impacto de vizinhança sem a participação da sociedade civil. No caso da OUCAB destacamos, além da Fábrica dos Sonhos, a Arena Palmeiras e o Shopping Bourbon.

Ademais, levamos em conta a norma oriunda das ações dos agentes envolvidos na intervenção, que por interesses diversos como a promoção imobiliária e a demanda por equipamentos sociais, recaem sobre os objetos técnicos instalados. Entre eles destacamos: i) os moradores que se manifestaram por meio do Movimento Água Branca, mas, que tiveram como interlocutora entre o Poder Público e a sociedade civil uma conselheira do CADES, além das associações de bairro e o Conseg; ii) representante do setor imobiliário, SECOVI.

Entre os tipos de pluralismos jurídicos mencionados no primeiro capítulo, observamos o seguinte: o pluralismo jurídico progressista, denominado comunitárioparticipativo. Nesta modalidade, o direito é negociado entre os agentes envolvidos por intermédio do Estado.

O processo de elaboração da norma municipal com objetivo de dispor sobre a OUCAB aconteceu em duas etapas: a primeira ao longo do licenciamento ambiental sob o intermédio do Poder Executivo e a segunda durante o trâmite na CMSP, no legislativo. A participação dos setores da sociedade civil começou na primeira etapa, com o processo de licenciamento ambiental do plano urbanístico contratado pela prefeitura.

Notamos uma política pública com apelo à concepção de cidade baseada no empreendedorismo urbano ou no urbanismo de mercado como afirma Ferreira (2010). Mas, a pesquisa com foco na OUCAB, nos permitiu verificar significativa valorização da participação social e, sobretudo, com valorização dos desejos dos setores mais carentes da sociedade civil. Julgamos que a participação na elaboração da Lei da OUCAB foi de tal importância, que foi possível encontrar um equilíbrio na correlação de forças em vigor. Os diferentes setores da sociedade tiveram que ceder em alguns 
aspectos e avançar em outros contando com a articulação com os vereadores e a mobilização da população afetada.

Constatamos, portanto, a ampliação da participação e do controle social na produção do direito com a finalidade última de interagir com o território usado. Partimos do pressuposto que o aumento da participação se deu sob o protagonismo da própria sociedade civil em seus diferentes setores.

O setor de moradores da região, bem assessorado por seus representantes, prepararam reuniões técnicas com professores universitários e técnicos da prefeitura sobre os assuntos de interesse, entre eles destacamos a questão das áreas contaminadas, obra de drenagem, habitação social, impactos cumulativos dos projetos urbanos inseridos no perímetro da OUCAB.

O esforço da comunidade de moradores levou os vereadores a irem até eles e, por meio de vistorias, conhecerem os reais problemas e demandas, além de realizar algumas das audiências públicas no bairro da OUCAB. A vistoria e conversas com a comunidade serviram de fonte ao texto da Lei.

Retomando Wolkmer (2001, p. 152) e seu ensinamento acerca da ciência jurídica, a fonte no domínio do Direito tem, substancialmente, sua origem nas "[...] relações sociais e às necessidades fundamentais desejadas, inerentes ao modo de produção da vida material, subjetiva e cultural [...]”. Por isso, a produção jurídica retrata as necessidades de um dado momento na história com relação direta nas práticas sociais vigentes.

A comunidade da Vila Chalot, representada pelo Movimento Água Branca e pela conselheira do CADES, está no local há mais de quarenta anos sendo inserida aos poucos na legalidade do Estado a começar pelo atendimento do direito à moradia. Sua organização normativa (auto regulação) que surge e se reproduz à revelia do Poder Público começa a influenciar a produção jurídica estatal.

Pela primeira vez, na capital paulista, se utilizou a Operação Urbana Consorciada como um instrumento urbano que não fosse excludente socialmente, pelo contrário, por meio da OUCAB foi imposta a obrigação de implantação de equipamentos sociais de moradia, de saúde, de educação e de lazer dentro de seu perímetro.

Demonstramos, também, no caso dos Centros de Treinamentos dos clubes de futebol, São Paulo Futebol Clube e Sociedade Esportiva Palmeiras, que os terrenos 
municipais deverão, obrigatoriamente, voltar à posse da municipalidade com a finalidade de se transformarem em parques públicos, o que contrariou um setor hegemônico politicamente, considerando que um ex-dirigente do clube atua como vereador.

Outra novidade trazida nesta Operação Urbana que valoriza os setores mais carentes é em relação ao perímetro expandido. Desta forma, rompe-se com a lógica de valorização de uma área restrita a poucos em detrimento de demandas essenciais como moradia em regiões carentes do entorno da OUCAB. Como demonstramos a arrecadação das Operações Urbanas da capital, que correspondem a 3\% da área urbanizada do município, representam aproximadamente seis vezes mais do que foi arrecadado pela venda de estoque adicional para construção para toda a cidade no mesmo período e esse dinheiro só podia ser utilizado no perímetro da Operação Urbana, da qual foi arrecadado.

O método inovador consiste em distribuir parte dos recursos arrecadados na OUCAB para habitação social e intervenções viárias dentro do perímetro expandido. A mudança foi tão bem aceita que foi introduzida na revisão do Plano Diretor Estratégico de São Paulo, em processo de aprovação. (junho de 2014)

Entretanto, se a construção normativa manifesta as relações de um período, vimos que outro agente, o setor imobiliário, também acabou por influenciar a nova Lei. A procura por residência no perímetro da OUCAB foi de tal intensidade, que se apresentou como uma norma preestabelecida. Desta maneira, é compreensível que o setor aproveite a oportunidade de tentar reordenar o território como lhe convier e opinar, por exemplo, em quantos subsolos para garagem ou qual a altura os edifícios devem ter.

Entendemos, porém, que o mercado imobiliário age de acordo com a demanda. Concordamos com o Sr. Della Manna do SECOVI que não é o setor imobiliário que estimula o uso do automóvel na capital paulista ao vender imóveis com três vagas na garagem, mas, o setor constrói e vende assim por causa da procura, ao contrário do que foi reclamado pela comunidade local.

Por mais que uma norma local seja progressista e proponha mudanças em seu recorte territorial, o alcance é limitado face à dinâmica territorial em escala nacional e até mundial. 
Do exposto, pensamos ter realizado um estudo à luz da norma e do território usado, que nos permitiu, como proposto nos objetivos, pensar a implantação de um instrumento de política urbana em andamento no Município de São Paulo - a OUCAB. 


\section{REFERÊNCIAS BIBLIOGRÁFICAS}

ANTAS JR., Ricardo Mendes. A norma e a técnica como elementos constitutivos da proposta teórica de Milton Santos. In: SOUZA, M. A. de (Org.), TERRITÓRIO BRASILEIRO usos e abusos. Campinas, Edições Territorial. 2003. p. 77 - 92

ANTAS JR., Ricardo Mendes. Território e regulação: espaço geográfico, fonte material e não-formal de direito. São Paulo: Associação Editorial Humanitas: Fapesp, 2005 .

BOBBIO, Norberto. Estado, governo, sociedade: por uma teoria geral da política. $1^{\text {a }}$ ed. 17 ${ }^{\mathrm{a}}$ reimpr. Rio de Janeiro: Paz e Terra, 2011a.

BOBBIO, Norberto. Liberalismo e democracia. $6^{\mathrm{a}}$ ed. $10^{\circ}$ reimpr. São Paulo: Braziliense, 2011b.

CARLOS, Ana Fani A. São Paulo: do capital industrial ao capital financeiro. In: CARLOS, Ana Fani A.; OLIVEIRA, Ariovaldo Umbelino (org.). Geografias de São Paulo: a metrópole do século XXI. $1^{\circ}$ ed. $1^{\circ}$ reimpressão. São Paulo: Contexto, 2010.

CASTELLS, Manuel; BORJA, Jordi. As cidades como atores políticos. In: Novos Estudos CEBRAP, $n^{\circ}$ 45, jul, 1996, p. 152-166

CHESNAIS, François. O capital portador de juros: acumulação, internacionalização, efeitos econômicos e políticos. In: CHESNAIS, François (org.). A finança mundializada: raízes sociais e políticas, configurações, consequências. São Paulo: Boitempo, 2005, p. 35-67.

CUSTÓDIO, Vanderli. A persistências das inundações na Grande São Paulo. 2002. Tese de Doutorado em Geografia Humana - Universidade de São Paulo.

DEÁK, Csaba. Acumulação entravada no Brasil/ E a crise dos anos 80. Espaço \& Debates, São Paulo, $\mathrm{n}^{\circ} 32$, p. 32-46, 1991. Disponível em: <http://www.usp.br/fau/docentes/depprojeto/c_deak/CD/3publ/91ace/index.html> Acessado em 05 de novembro de 2012.

Csaba. Globalização ou crise global? Comunicação apresentada no Encontro Nacional da ANPUR, Rio de Janeiro, 2001. Disponível em: <http://www.usp.br/fau/docentes/depprojeto/c_deak/CD/3publ/01glob-cr/index.html> Acessado em 04 de novembro de 2011.

DÉAK, Csaba; SHIFFER, Sueli. A metrópole de uma sociedade de elite. Artigo apresentado na Universidade Johns Hopkins, Baltimore (no prelo), 2007. Disponível em: <http://www.usp.br/fau/docentes/depprojeto/c_deak/CD/3publ/07sp-metr-elit/07SP-Met-po.pdf> Acessado em 06 de novembro de 2011.

DI PIETRO, Maria Sylvia Zanella. Parcerias na administração pública: concessão, permissão, franquia, terceirização e outras formas. 4a ed. São Paulo: Atlas, 2002.

FARIA, José Eduardo. O Estado e o Direito depois da crise. São Paulo: Saraiva, 2011. 
FERREIRA, João Sette Whitaker. O mito da cidade-global: o papel da ideologia na produção do espaço urbano. Petrópolis, RJ: Vozes; São Paulo, SP: Editora Unesp; Salvador, BA: Anpur, 2007.

, João Sette Whitaker . Cidades para poucos ou para todos? Impasses da democratização das cidades no Brasil e os riscos de um urbanismo às avessas . In: Francisco de Oliveira, Cibele Risek, Ruy Braga. (Org.). Hegemonia às avessas: economia, política e cultura na era da servidão financeira. São Paulo: Boitempo Editorial, 2010, v. , p. 185 - 213.

FIX, Mariana. Parceiros da exclusão: duas história de construção de uma "nova cidade” em São Paulo: Faria Lima e Água Espraiada. São Paulo: Boitempo, 2001.

FOUCAULT, Michel. A verdade e as formas jurídicas. Rio de Janeiro: Nau, 1996.

GALEANO, Eduardo. Las venas abiertas de América Latina. Buenos Aires: Siglo Veintiuno Editores, 2010.

GÜELL, José Miguel Fernándes. Planificación estratégica de ciudades. Barcelona: Editorial Gustavo Gilli S.A., 1997.

HARVEY, David. A produção capitalista do espaço. São Paulo: Annablume, 2005.

HOBSBAWN, Eric. Era dos extremos: o breve século XX: 1914-1991. 2a ed. 29 reimpr São Paulo: Companhia das Letras, 2004

LOPES, José Rinaldo de Lima. O direito na história. São Paulo: Max Limonad, 2000.

MARICATO, Ermína; FERREIRA, João Sette Whitaker. Operação Urbana Consorciada: diversificação urbanística participativa ou aprofundamento da desigualdade? In: OSÓRIO, L. (org.) Estatuto da Cidade e reforma urbana: novas perspectivas para as cidades brasileiras. Porto Alegre: Sérgio Antônio Fabris, 2002, p. 215-250.

Vozes, 2008.

Ermínia. Brasil, cidades: alternativas para a crise urbana. $3^{\circ}$ ed. Petrópolis, RJ:

MARX, Karl; ENGELS, Friedrich. Manifesto Comunista. Edição eletrônica: Ed. Ridendo Castigat Mores (www.jahr.org), 1999.

MOVIMENTO ÁGUA BRANCA. Gestão do Solo Urbano - Enchentes, Várzea do Tietê, Operação Urbana Água Branca. São Paulo, 12 de janeiro de 2011. Disponível em: $<$ http://movimentoaguabrancasp.blogspot.com.br/2011/01/gestao-do-solo-urbanoenchentes-varzea.html> Acessado em 26 de maio de 2013.

PRADO JÚNIOR, Caio. História e desenvolvimento: a contribuição da historiografia para a teoria e prática do desenvolvimento brasileiro. $3^{\mathrm{a}}$ ed. $1^{\circ}$ reimpr. São Paulo: Editora Brasiliense S.A., 1999.

RAMOS, Aluísio Wellichan. Cotidiano, espaço e tempo de um antigo bairro paulistano: transformações da cidade e a dimensão do vivido. GEOUSP - Espaço e Tempo, São Paulo, No 15, pp. 77 - 103, 2004. Disponível em: 
<http://www.geografia.fflch.usp.br/publicacoes/Geousp/Geousp15/Artigo6.pdf> Acessado em 27 de maio de 2013.

RAMOS, Aluísio Wellichan. A cidade como negócio: aspectos da atuação do setor imobiliário e da relação público-privado na Barra Funda e na Água Branca (município de São Paulo) - um exame crítico da Operação Urbana Água Branca e do projeto "bairro novo". 2006. Tese de Doutorado em Geografia Humana - Universidade de São Paulo.

ROLINIK, Raquel. A cidade e a lei: legislação, política urbana e territórios na cidade de São Paulo. $3^{\text {a }}$ ed. São Paulo: Studio Nobel: FAPESP, 2003.

SANTOS, Boaventura de Sousa. O discurso e o poder: ensaio sobre a sociologia da retórica jurídica. Em Boletim da Faculdade de Direito. Universidade de Coimbra, número especial em homenagem ao Prof. Dr. J. J. Teixeira Ribeiro, Coimbra, 1979, pp. 227-341.

SANTOS, Milton. O retorno do território. In: OSAL : Observatório Social de América Latina. Ano 6 no. 16 (jun. 2005). Buenos Aires: CLACSO, 2005.

2007.

O espaço do cidadão. $7^{\text {a }}$ ed. São Paulo: Editora Universidade de São Paulo,

Metamorfoses do espaço habitado: fundamentos teóricos e metodológicos da geografia. 6a ed. São Paulo: Editora Universidade de São Paulo, 2008a.

Técnica, espaço, tempo: globalização e meio técnico-científico-informacional. 5ª ed. São Paulo: Editora Universidade de São Paulo, 2008b.

Por uma outra globalização: do pensamento único à consciência universal. $15^{\mathrm{a}}$ ed. Rio de Janeiro: Record, 2008c.

A natureza do espaço: técnica, tempo, razão e emoção. 4a ed. 5a reimpr. São Paulo: Editora Universidade de São Paulo, 2009a.

Metrópole corporativa fragmentada: o caso de São Paulo. 2a ed. São Paulo: Editora Universidade de São Paulo, 2009b

Por uma economia política da cidade: o caso de São Paulo. 2a ed. São Paulo: Editora Universidade de São Paulo, 2009C

SANTOS, Milton; SILVEIRA, María Laura. O Brasil: território e sociedade no início do século XXI. 11 a ed. Rio de Janeiro: Record, 2008.

SINGER, Paul. Desenvolvimento Econômico e Evolução Urbana. São Paulo: Editora Nacional, 1968.

SOUZA, Maria Adélia Aparecida. Território e lugar na metrópole: revisitando São Paulo. In: CARLOS, Ana Fani A.; OLIVEIRA, Ariovaldo Umbelino (org.). Geografias de São Paulo: a metrópole do século XXI. $1^{\circ}$ ed. $1^{\circ}$ reimpressão. São Paulo: Contexto, 2010. 
SPOSATI, Aldaíza. Cidade em pedaços. TOLEDO, José Roberto de (org.). São Paulo: Brasiliense, 2001.

VAINER, Carlos Bernardo. Pátria, empresa e mercadoria: Notas sobre a estratégia discursiva do Planejamento Estratégico Urbano. In: ARANTES, Otília; VAINER, Carlos; MARICATO, Ermínia. A cidade do pensamento único: desmanchando consensos. $5^{\circ}$ ed. Petrópolis, RJ: Vozes, 2009, p. 75-104.

WEBER, Max. A ética Protestante e o espírito do capitalismo. $4^{\mathrm{a}}$ ed. $11^{\mathrm{a}}$ reimpr. São Paulo: Martin Claret, 2012.

VITTE, C. C. S. Desenvolvimento econômico e a divisão espacial de consumo nos municípios e na Região Metropolitana de Campinas (SP). In: X Colóquio Internacional de Geocrítica, 2008, Barcelona. Programa para el X Colóquio Internacional de Geocrítica. Barcelona: Universidade de Barcelona, 2008. p. 1-14.

WOLKMER, Antônio Carlos. Pluralismo Jurídico: fundamentos de uma nova cultura no direito. 3a ed. São Paulo: Editora Alfa Ômega Ltda, 2001.

\section{Sites consultados}

http://raquelrolnik.wordpress.com/2011/11/03/operacao-agua-brancabarra-fundaprefeitura-anuncia-noticia-requentada. Acesso em: 20 nov. 2011.

http://www.estadao.com.br/noticias/impresso $\% 2$ creforma-de-galerias-da-pompeia-soacaba-em-2014-\%2c788294\%2c0.htm Acesso em: 21 out. 2011.

http://www1.folha.uol.com.br/cotidiano/881841-circulacao-de-trens-na-lapa-e-na-barrafunda-e-interrompida.shtml. Acesso em: 21 out. 2011.

http://www1.folha.uol.com.br/fsp/opiniao/fz1704200110.htm Acesso em: 25 mar. 2014. http://cidadedosambarj.globo.com. Acesso em: 10.03.2012

http://www.tecnisa.com.br. Acesso em: 20.10.2011.

http://www.jardimdasperdizes.com.br/midia/revista\#page/2. Acesso em: 03 mar. de 2013.

http://www.prefeitura.sp.gov.br/cidade/secretarias/upload/meio_ambiente/arquivos/apre sentacao_cades_leste.pdf> Acesso em: 14 mar. 2014.

http://www.prefeitura.sp.gov.br/cidade/secretarias/upload/chamadas/trouc_rio_verdejacu_-_versao_consulta_publica_1289322052.pdf Acesso em: 14 mar. 2014.

http://www.prefeitura.sp.gov.br/. Acesso em: 31 jan. 2014.

http://www.prefeitura.sp.gov.br/cidade/secretarias/upload/desenvolvimento_urbano/sp_ urbanismo/arquiarq/ouab/ouab_relatorioreuniaotecnica09jan.pdf. Acesso em: 12 fev. 2014. 
http://gestaourbana.prefeitura.sp.gov.br/novo-pde-macroareas. Acesso em: 14 mar. 2014.

http://www.conseglapa.com.br/o-que-e-o-conseg/. Acesso em: 22 fev. 2014.

http://www.paulofrange.com.br/noticias_237.html. Acesso em: 16 mai. 2014.

http://movimentoaguabrancasp.blogspot.com.br/2013/10/podem-fazer-com-o-pl-do-

plano-diretor-o.html. Acesso em: 28 mai. 2014.

http://www.redebrasilatual.com.br/cidadania/2013/10/ministerio-publico-tomaramedidas-judiciais-contra-operacao-urbana-agua-branca-na-zona-oeste-de-sp-9826.html. Acesso em: 28 mai. 2014.

http://cidadeaberta.org.br/comissao-do-arco-do-futuro-ouve-secretario-dedesenvolvimento-urbano/ Acesso em: 14 mar. 2014.

\section{Leis}

BRASIL. Lei $\mathrm{n}^{\circ} 10.257$, de 10 de junho de 2001. Regulamenta os art. 182 e 183 da Constituição Federal, estabelece diretrizes gerais da política urbana e dá outras providências.

SÃO PAULO (Município). Lei no. 7688, de 30 de dezembro de 1971. Dispõe sobre instituição do Plano Diretor de Desenvolvimento Integrado do Município de São Paulo.

SÃO PAULO (Município) Lei no.11.774 de 18 de maio de 1995 - Operação Urbana Água Branca.

SÃO PAULO (Município) Decreto $n^{\circ} 42.319$, de 21 de agosto de 2002. Dispõe sobre as diretrizes e procedimentos relativos ao gerenciamento de áreas contaminadas no Município de São Paulo.

SÃO PAULO (Município). Lei no.13.430, de 13 de setembro de 2002. Dispõe sobre o Plano Diretor Estratégico do Município de São Paulo.

SÃO PAULO (Município). Lei Ordinária no. 14.933 de 5 de junho de 2009. Institui a Política de Mudança do Clima no Município de São Paulo.

SÃO PAULO (Município). Câmara Municipal. Processo no. 01-505 de 2012, sobre o Projeto de Lei da OUCAB. 


\section{APÊNDICE A}

Entrevista: Senhor Eduardo Della Manna, representante do SECOVI (25/02/2014)

Della Manna: A primeira lei da operação urbana água branca, que é de 1995, quando foi pensada pela prefeitura no âmbito da EMURB, ela imaginava que aquela região pudesse se constituir num novo polo terciário, de prestação de serviços, uma região central, bem dotada de infraestrutura, descontando os problemas que existiam e ainda existem de drenagem, podia ser um novo polo de prestação de serviços com escritórios. Mas, a realidade não confirmou isso, o novo polo de terciário acabou se consolidando na região da Berrini e tende a se concentrar mais ao sul mesmo. Então a realidade mostrou que quando você quer um polo de serviços, não adianta ter apenas um plano urbanístico, você precisa ter um conjunto de ações que consolidem o novo polo, por exemplo: incentivos fiscais para as empresas irem, não adianta apenas incentivos urbanísticos, para o empreendedor ir lá e construir prédios de escritórios, que é a base física das empresas, você precisa dar incentivos para determinadas atividades econômicas. Por exemplo, eu quero incentivar um novo polo cinematográfico na região, então é necessário criar uma lei que dê incentivos fiscais pra incentivar as atividades relacionadas ao ramo cinematográfico poder se instalar, então é um conjunto de ações, não é só uma operação urbana que determina isso.

Foi o que aconteceu, na realidade, aquela região teve um crescimento muito grande de lançamentos imobiliários, então, aqueles estoques de potenciais adicionais de construção para a região eram muitos grandes para os usos não residenciais e muito pouco para o residencial. Os anos foram passando e aquele estoque residencial foi sendo consumido e no começo da década dos anos 2000, a prefeitura percebeu que precisava rever a Operação e aproveitava que o Estatuto da Cidade instituía a Operação urbana com CEPAC, era o momento de trazê-lo para essa Operação.

A coisa foi andando muito lentamente até que no final da gestão do prefeito Gilberto Kassab, a SP Urbanismo, que é uma empresa criada da cisão da EMURB em SP Obras e SP Urbanismo, então no final da gestão do Kassab a coisa estava gritante, havia um volume muito grande de processos só pra uso residencial, eles perceberam que alguma coisa precisava mudar e rápido.

Eles constituíram um grupo para a revisão da Lei da Operação e chegaram a consultar o Secovi em 2012 e nós percebemos que eles estavam trabalhando com um novo conceito, com um projeto bastante interessante com usos mistos garantindo não apenas densidades construtivas, mas, densidades demográficas. Mas a gente percebeu que no PL tinham alguns problemas que precisavam ser ajustados, por exemplo: eles estavam exigindo que os empreendimentos adotassem uma área de permeabilidade de 30\%, todo mundo sabe que aquela região tem problemas de drenagem, encostado no leito do rio Tietê, e não tem a menor eficácia você deixar $30 \%$ de área permeável no terreno, a terra não absorve aquela água, seria muito mais eficaz se a lei pudesse deixar para o empreendedor a opção de trabalhar com caixas de retenção, então, nós apresentamos nosso ponto de vista, outra coisa foi o gabarito dos prédios, que era muito baixo, os empreendimento não iam conseguir oferecer a densidade demográfica que a Operação pretendia, então foram apresentadas várias ideias que não contrariavam o espírito da Operação Urbana, apenas davam um refinada no sentido de aperfeiçoar a lei.

Mandamos um ofício para a SP Urbanismo, mas o setor foi surpreendido quando foi publicado no DO no dia 07/11/2012 sem nossas sugestões. Então o PL foi tramitar na CMSP e a nova gestão (HADDAD) resolveu tocar adiante, eles conseguiram o parecer favorável das Comissões e votaram em primeira e aí abriram espaço para as Audiências Públicas, que de forma democrática e republicana, nós comparecemos na Audiência Pública organizada pela Comissão de Política Urbana em maio de 2013, no qual enviamos um ofício e depois participamos em 22/05 na Audiência Pública promovida pela Comissão de Finanças, na qual enviamos o mesmo ofício e enviamos também para a SP Urbanismo, exatamente o mesmo texto.

Então a gente falava da taxa de permeabilidade mínima no lote, que a gente achava que os $30 \%$ nos parecia exagerada e pouco eficaz e isso mudou, eles mantiveram a taxa, mas, abriram a possibilidade de o empreendedor fazer a caixa de retenção desde acompanhada de um laudo e 
um projeto técnico que garantisse o retardamento da saída da água, nós também fizemos a sugestão da cota de terreno máxima no lote, que era de 30 e caiu para 25, e outras sugestões relacionadas à categoria de vias, enfim, um conjunto bastante grande, tudo de forma muito clara e transparente, esse documentos são públicos. Muita coisa foi incorporada, outras coisas não.

Uma Operação Urbana é uma parceria público-privada, para ela dar certo, ela precisa atender minimamente os interesses o setor imobiliário, senão não tem comprador para os CEPACs e recursos para a Prefeitura fazer todas aquelas obras do plano de intervenções. Acho que a gente conseguiu uma Lei, que não foi favorável a todos os nossos interesses, mas foi o que foi possível naquele momento e numa democracia é assim que funciona, você têm diversos interesses na cidade que estão em jogo e ninguém pode entrar no jogo querendo ganhar tudo.

$\mathrm{O}$ grande ganho foi realmente o adensamento populacional e não o construtivo e o uso misto, que é uma nova visão de cidade e que foi incorporado no PL da revisão do Plano Diretor da cidade.

Clayton: a conversa é mais fácil com o Executivo ou com o Legislativo?

Della Manna: a conversa com o Executivo sempre é mais técnico, a discussão no legislativo não está ligada a aspectos técnicos, são muito poucos os interlocutores na CMSP que estão preparados para uma discussão técnica, o Nabil, o Police Neto, o Andrea Matarazzo, eu ficaria nesses três.

Clayton: e a sociedade civil num modo geral?

Della Manna: existe um grupo que é radicalmente contra a "verticalização predatória", o Defenda São Paulo, o MOVER, e nós enfrentamos esses grupos o tempo todo. Só pra você ter uma ideia, o setor, nos últimos dez anos tem produzido e vendido em média na cidade de SP 30.000 unidades por ano em média, $40 \%$ são unidades de 2 dormitórios e $35 \%$ de 3 dormitórios, ou seja, destina à classe média, que trabalha em SP e quer morar em SP, o Poder Público tem que dar uma resposta pra isso e tem que ser pela verticalização, a cidade cresceu horizontalmente mais do que deveria e você precisa colocar as pessoas onde tem infraestrutura, na região central.

Esses Movimentos que são contra a verticalização, é uma visão muito irresponsável e egoísta, porque eles já moram numa região bem servida de infraestrutura e não quer mais ninguém do lado deles.

A cidade tem um grande problema, as pessoas falam: o imóvel, o apartamento está ficando muito caro. Por que? Porque o custo da terra, que é a matéria prima, está ficando muito caro em SP, porque os coeficientes de aproveitamentos são baixos e porque simplesmente a terra está acabando. A indústria imobiliária começou a construir nos municípios vizinhos, só que o efeito perverso disso é que as pessoas que compram esses imóveis continuam trabalhando em SP causando um problema sério de mobilidade.

Por isso o setor concorda que a saída é adensar as regiões dotadas de infraestrutura, somos favoráveis ao proposto no Plano Diretor, que é o adensamento dos eixos próximos das ferrovias, criam-se coeficientes de aproveitamento e cotas de terreno por unidade. É assim que se ajuda a resolver os problemas, é fundamental que o governo estadual continue investindo em metrô e a gente tem que garantir adensamento sem causar mais problema de infraestrutura.

Clayton: Uma das maiores reclamações foi a questão do subsolo, qual é o posicionamento do setor em relação a isso?

Della Manna: É muito simples. A relação do edifício com a cidade, uma maneira de estabelecer uma boa relação é abrir o piso térreo para o público com comércio, se vc limita a execução de subsolo, você tem que criar o sobresolo o que limita ainda mais a relação entre o edifício e a população. Não adianta limitar o número de vagas por unidade, as pessoas procuram apartamentos com vagas de automóvel porque já tem o automóvel, ninguém compra carro porque tem um apartamento com três vagas, mas, compra um apartamento com três vagas porque tem três carros. Todo mundo quer carro, o sujeito junta dinheiro para comprar carro, é essa nossa realidade, hoje se financiam carros em dezenas de prestações, o governo federal tirou o IPI para aumentar as vendas do automóvel, onde as pessoas vão estacionar se não houver garagem? Na rua e então se limita o leito carroçável, tem que se ter um balanceamento. A gente precisa de uma oferta mínima de qualidade de transporte público, mas nossa rede é limitada. 
Quando o setor imobiliário compra CEPACs ou paga contrapartidas ambientais, o setor espera que esse recurso seja destinado a essas coisas.

Clayton: Quanto aos grandes projetos urbanos: Arena Palmeiras, Fábrica dos Sonhos, Shopping Bourbon, qual a posição do Secovi?

Della Manna: Existe uma legislação que obriga o Relatório de Impacto de Vizinhança, e esse estudo obrigou o empreendimento da Arena a cumprir várias exigências e eles cumpriram rigorosamente. A mesma coisa com a Fábrica dos Sonhos.

Clayton: Em relação às áreas contaminadas?

Della Manna: A gente vem se aperfeiçoando nisso, que é uma coisa nova para nós. A industria imobiliária não polui, mas remedeia o problema. Nós nos limitamos a contratar empresas que fazem o trabalho. O problema é que as análises feitas pelos órgãos ambientais são muito lentas e desgastantes para nós.

Clayton: E suas considerações finais sobre a nova Lei?

Della Manna: Acho que o valor do CEPAC ficou muito alto, no PL o valor era bem mais baixo, por que jogaram isso tão alto? É que durante as discussões nas AP resolveram fazer tantas obras, tantas intervenções, que tiveram que aumentar o valor do CEPAC. Agora, vai ter Operação na medida em que tiver interesse do setor imobiliário.

A Lei ainda está no papel, não dá para saber se ela vai dar certo.

Em relação às Operações anteriores, elas já cumpriram seu papel, o setor já consumiu o potencial construtivo e falta a Prefeitura fazer a parte dela, que é gastar o dinheiro acumulado dentro de perímetro, mas é tudo muito lento e burocrático. Agora a Prefeitura tem que pensar nas novas Operações e o próprio Arco Tietê. Hoje a gente tem massa crítica para saber o que pode melhorar, o que deu certo e o que deu errado.

O que pode ocorrer, por exemplo, é que a comissão gestora da Operação tenha autonomia para fazer certas alterações sem que tenha que se rever a Lei, sem ter que mexer na Lei como ocorreu com a OUCAB, isso da maior agilidade ao processo.

\section{APÊNDICE B}

Entrevista feita em 04 de outubro de 2012 com a Conselheira Sra. Ros Mari Zenha, integrante do Conselho Municipal do Meio Ambiente e Desenvolvimento Sustentável (CADES), que representa a Macro Região Centro Oeste (Butantã, Lapa e Pinheiros).

Sra. Ros Mari Zenha: É um território, que no passado, grande parte dele, teve uma ocupação fabril. Tanto é que a gente tem muita área contaminada na região, até porque você tinha muita empresa que fazia trilho de trem e esse tipo de material era lavado com solvente e era jogado no solo, então, você tem muito problema de contaminação inclusive do lençol freático, não só do solo.

É uma região que foi mudando, nós que somos geógrafos sabemos disso, ela foi mudando, o território foi mudando de atividade, as indústrias acabaram se deslocando pra outras coisas, as próprias cadeias produtivas se rearranjaram e ela passou a ser uma região, que sem sombra de dúvida, tem potencial, obviamente, de ser melhor ocupada, tem condições disso, só que essa ocupação deveria ser feita sob outras bases, então o que que aconteceu, surgiu a grande Operação Urbana Água Branca.

Essa Operação Urbana, a primeira, data da época da gestão do Maluf, quer dizer, ela está em vigor, ela tem inclusive recursos que foram obtidos por meio da venda de potencial construtivo naquela região e, também, tem até um conselho gestor, só que por que que agora ela tá de novo voltando a baila? Porque ela é anterior à lei federal do Estatuto da Cidade, e como o Estatuto da Cidade agora exige que todas as Operações Urbanas tenham primeiro Estudo de Impacto Ambiental EIA RIMA, que antes não tinha e segundo, que ela tenha um conselho gestor que incorpore a participação da sociedade, que a outra também não tinha. $\mathrm{O}$ conselho gestor era única e exclusivamente formado por representantes do aparelho do Estado. Então ela teve que se 
adaptar e nós estamos num pleno processo de transformar a Operação Urbana Água Branca numa Operação Urbana "Consorciada" Água Branca.

Qual é o momento que nós estamos vivendo agora? Só para você entender o processo, foi feito um Estudo de Impacto Ambiental e o Relatório de Impacto Ambiental, EIA-RIMA, o empreendedor é a SP Urbanismo, que responde à Secretaria Municipal de Desenvolvimento Urbano, a SMDU, que fez uma proposta preliminar de ocupação de todo o terreno da Operação, isso se tornou objeto do estudo do EIA-RIMA, do Estudo de Impacto Ambiental.

O Estudo de Impacto Ambiental foi analisado durante onze reuniões na Câmara Técnica do CADES, que é o Conselho de Meio Ambiente, da qual nós da sociedade civil fizemos parte, eu representei a macro oeste e estive presente em todas essas reuniões, dessas reuniões saiu um parecer técnico, que foi discutido com o Decont, da Secretaria, esse parecer técnico foi encaminhado ao CADES, foi defendido, foi aprovado no CADES e agora, Clayton, tá num momento em que a SP Urbanismo tem que entregar ao CADES antes que seja encaminhado para a Câmara Municipal, o projeto de lei da Operação Urbana Consorciada Água Branca. Ficou de passar por nós antes de chegar na Câmara, eu estou exigindo isso sistematicamente, por quê? Porque o conteúdo do projeto de lei vai ter que refletir, ele vai ter que espelhar todos os condicionantes técnicos que nós colocamos no parecer técnico e eu estudei profundamente a Operação, do ponto de vista técnico, essa foi a única que eu participei profundamente por toda a documentação e o parecer técnico que saiu foi bastante razoável, óbvio que você poderia falar, poderia ter sido melhor nisso ou naquilo, mas, houve muito cuidado da sociedade civil em monitorar e eu acho que até dos próprios técnicos do Decont, quando eu falo, eu falo os técnicos do Decont, não é a estrutura da Secretaria, que é diferente, é como a gente, nós somos técnicos do IPT, uma coisa são os técnicos do IPT, outra coisa é o Secretário de Tecnologia.

Então, o que aconteceu? Saiu um produto bastante razoável, no meu entender, teve uma participação ativa, eu tive muito apoio, felizmente, de vários colegas da área técnica, que ajudaram voluntariamente nos estudos que a gente acabou fazendo, levantamos questões de mudanças climáticas, de contaminação do lençol freático e aí saiu.

Agora, todo esse conteúdo, técnico, ele vai ter que ser refletido no Projeto de Lei, e aí, o que nós conseguimos amarrar, acho que duas coisas inovadoras no parecer do CADES, que o Projeto de Lei não vai passar pela Câmara antes de passar pelo CADES, com que perspectiva, que se eventualmente houver uma atuação inadequada de fazer um Projeto de Lei que não reflita nada do que foi dito até agora, nós temos ainda uma instância pra meter a boca no trombone lá no CADES, chamar Ministério Público, é levar à luta, se vai direto pra Câmara, a coisa muda de figura, e por outro lado, até para saber o que vai ser colocado, porque têm coisas que nós colocamos no Parecer, e eu, pra mim tenho claro, que ao chegar na Câmara vai ser um tumulto generalizado, a luta na Câmara vai ser um segundo round poderoso, por que? Só vou te dar um exemplo: nós, no parecer técnico, estamos limitando a construção do subsolo a um único subsolo, por ser área de várzea, isso vai ser uma guerra, a hora que chegar na Câmara, por que isso? Porque nossa ideia era o seguinte: se nós estamos lutando, e essa foi nossa perspectiva enquanto sociedade civil, por uma cidade, por um território, como dizia o Milton Santos, que seja sustentável, que respeite o meio físico, os geógrafos e os geólogos têm isso como a coisa mais importante, que respeite o meio físico, sustentável e uma cidade inclusiva e democrática, e que nós sabemos que nós temos que tornar uma cidade democrática aproximando o trabalho de moradia, só que tudo isso tem que ser feito de maneira inclusiva, a melhor forma pra isso, é você poder oferecer um ambiente construído em que a população de classe média baixa, classe média média como a gente tenha possibilidade de acesso, e a tendência até hoje dessas operações, foi liberar espaço para empreendimento de construção de alto padrão, quando você for fotografar aqui a Vila Romana, não precisa ir muito longe, isso aqui era um bairro totalmente residencial, esse meu prédio aqui, que tem mais de trinta anos, oito andares era o máximo que tinha, a Vila Leopoldina hoje se transformou num paliteiro, você leva meia hora pra sair da garagem, ali também tem a Operação Urbana Leopoldina.

Então veja, o que a gente estava tentando fazer na Operação Urbana Água Branca, é um perímetro que conta com uma malha de transporte razoável, com perspectiva de melhorar mais, com essa previsão de vir metrô aqui para Cerro Corá, a CPTM, que tá agora modernizando ali, 
onde que o terminal da Lapa, então tudo isso tem todo um território bem dotado do ponto de vista de transportes, é um território bem dotado, razoavelmente, pelo menos até agora, de equipamentos sociais, mas que vai ter que ter uma previsão muito maior, porque a Operação Urbana Água Branca tem teoricamente a previsão de trazer pra cá mais 80.000 pessoas, um município, e a pergunta que se fazia era: que pessoas? Porque se for pra fazer prédio de alto padrão, qual que é o engodo, qual é a enganação que a prefeitura vende pra população? Ela fala em cidade compacta. O secretário Bucalen volta e meia fala, eu tive num debate com ele sobre isso, cidade compacta, obviamente que todos nós que somos da área, geógrafos, geólogos engenheiros e os arquitetos sabemos que você ter uma cidade compacta de uma maneira bem feita, bem planejada, não é uma má ideia, até porque você economiza energia, você diminui a concentração de gazes do efeito estufa, você diminui a distância entre local de moradia e local de trabalho, você pode dar mais qualidade de vida pra população.

agora cidade compacta, não é cidade compacta de concreto, porque o que eles propõem isso, eles enganam e aí, quando eu falo em cidade compacta, ah nós estamos verticalizando porque a gente precisa preencher os vazios, você vai ver aqui que a população que vem é uma população de alta renda, com apartamentos que são imensos, onde moram três pessoas, uma média de 3 a 4 pessoas e que ocupa quarteirões enormes, onde antes você tinha casinhas, né, você muda todo o desenho do espaço urbano, o espaço público deixa de ser uma continuidade do espaço privado, né, é como dizia aquele meu amigo que morou na França, puxa, mas, quando você ficou tanto tempo na França, você morava num lugar tão pequenininho, porque ele morava numa espécie de um sótão, e ele dizia, mas gente, eu abria minha porta e eu tinha Paris aos meus pés, eu não preciso ter um apartamento de milhões de metros, quando eu tenho uma cidade, onde eu tenho parques, onde você vai para os cafés, onde você vive a urbe, qualidade de vida, aqui não, nada é continuidade de nada.

Então o que aconteceu, Clayton, com isso a Operação Urbana tá andando, não chegou no CADES ainda o Projeto de Lei, mas independente disso, tem coisas surreais que depois você vai ver, que nós temos várias ações no Ministério Público em relação a isso, a própria Operação Urbana, tem coisas no seu perímetro, que não foram levadas em conta no EIA-RIMA, uma delas é a Arena Multiuso Palmeiras, não se estuda o impacto cumulativo, nó estamos levando essa discussão na Câmara, no Projeto de Lei que o Kassab acabou de mandar que diz tudo de impacto de vizinhança, você não pode fazer um estudo de impacto ambiental e de vizinhança na coisa isolada, a Operação Urbana, o perímetro da Água Branca inclui, pra você ter uma noção: Arena Multiuso Palmeiras, West Plaza, o Bourbon, Fábrica dos Sonhos, a Cidade do Samba, não, agora vai fazer um hotel, tá fazendo um baita de um hotel agora com a Odebrecht, que ali numa região, quer dizer, tudo isso não entrou no estudo de impacto ambiental da Operação, foi estudado em si, no caso da Arena Multiuso Palmeiras foi feito um EIV, um Estudo de Impacto de Vizinhança, onde o cara viu ali um raio minúsculo, e não tem participação nenhuma, a ideia é essa, nenhuma, tanto é que do ponto de vista técnico.

Tem muitos técnicos, muitos colegas de áreas aí, que já estão prevendo, terão problemas imenso na hora que isso aí vier a funcionar, acústico, a parte de polo gerador de tráfego, porque isso aí não é um estádio para jogos de fim de semana, é uma arena multiuso, isso é o que vai dar rentabilidade para o empreendimento, então eles vão ter shows, a semana inteira, como vai ocorrer na Fábrica dos Sonhos, que a ideia é ter apresentação de escola de samba e sem contar a questão ambiental, que lá então é mais terrível, ali tinha uma associação de japoneses que jogavam rúgbi, era da associação dos estudantes de medicina, os caras tiraram tudo e eu lembro que eu ainda tentei segurar, porque infelizmente, os técnicos da Secretaria tiveram que engolir o sapo, como não tem que ter participação, não teve nada, o EIV entrou lá, a Secretaria de Verde fez o estudo por meio do Decont e aí foi aprovado o Parecer, só que, eu como Conselheira tenho poder de convocar a Câmara Técnica, que estudou e eu convoquei, nossa foi um constrangimento generalizado, convoquei toda a Câmara Técnica, eu nem tinha nada a ver com isso, para que me apresentassem o Parecer Técnico. Nesse dia foi até um chefe de gabinete do Kassab, pedi para o colega, aliás um rapaz excelente da SVMA, o menino apresentar, ele apresentou e eu falei assim para eles, falei, poxa olha, eu tenho certeza que os meus colegas da Secretaria, que são da área técnica, devem talvez, infelizmente vocês já aprovaram, falei pro 
pessoal lá da prefeitura, mas acho que eles tinham a mesma ideia que eu, isso deveria ser um grande impacto urbano pra cidade de São Paulo, não para zona oeste, um parque urbano, lá passa um belo córrego, e aí o pessoal da Secretaria, os técnicos disseram, é, agente também acha, aquilo foi um constrangimento, eu falei, secretário, como é que isso aí foi aprovado.

O cara do Kassab falou que já tinham conversado com os caras das escolas de samba, queria tirar as escolas de samba debaixo dos viadutos e não sei o que, aí eu falei, mas o senhor vai me impermeabilizar tudo, inclusive as medições de ruído estão comprometidas, a população do entorno nem se dá conta do que os espera, eu era uma grande aliada lá, falei pro assessor do Kassab, não é possível que o senhor não entenda, então eu pediria por gentileza, eu quero que conste a minha posição, que conste em ata no Diário Oficial, eu tenho até hoje que eu levei no Ministério Público, que eu sou contra, que isso deveria ser um parque urbano pra cidade, entreguei por escrito, só que eles agem à revelia, então, quer dizer isso valeu para a arena, valeu para cidade dos sonhos, tá valendo pra esse hotel que o cara vai fazer agora,

E aí, pra terminar, vou te dar um exemplo, como as coisas são difíceis, até em relação a própria sociedade civil, seus amigos do Decont sabem disso, nós defendemos profundamente que tem que ter um estudo das 5 bacias, o perímetro da Operação Urbana inclui 5 córregos, Água Branca, Água Preta, Quirino dos Santos, Sumaré e Pacaembu, tá mais do que dito, toda área técnica sabe, que tá sendo feito, tá em andamento um estudo de macrodrenagem da bacia do Alto- Tietê, macrodrenagem, uma preocupação imensa da secretaria em fazer, e lá dentro tem os 5 córregos.

O Kassab contratou, por um valor, eu acho de 4 milhões e meio, um estudo, com o departamento de hidráulica da escola politécnica da USP pra fazer um Plano Diretor de drenagem e destinação de águas pluviais de São Paulo, o pessoal fez, apresentou no instituto de engenharia e eu estou pedindo que seja apresentado no CADES e ainda não apresentaram, colocamos no Parecer, nenhuma intervenção vai ser feita no perímetro sem que as 5 bacias sejam estudadas na sua totalidade e eu pedi ainda que constasse em ata algo além, que se alguma intervenção viesse a ser feita, que esse estudo do Plano Diretor fosse consultado e da bacia do Alto-Tietê também, essas coisas tem que ser costuradas, tem que se conversar, bom, o que fizeram recentemente, resolveram que iam começar já as obras do córrego da Água Preta, que dá enchente aqui na Pompéia, e qual é a solução tecnológica? É que há galerias no paralelo, eles desistiram dos piscinões, o que aconteceu, eles iam ampliar as galerias, só que sem o estudo, conclusão, você não acredita, aí só um parêntese, começou uma gritaria, inclusive os jornais aqui do bairro e algumas outras entidades detonando a secretaria, o decont, porque não estava deixando começar a obra, deve já estar tendo uma pressão para começar a fazer a obra, que é uma obra acho, que da ordem de 450 milhões, um negócio que não é pequeno, pela SIURB, e aí como precisa ter o parecer da Secretaria do Verde, a Secretaria do Verde falou que não, à luz do Parecer que nós aprovamos lá, está que toda e qualquer obra individualizada em qualquer córrego não pode ser feita sem um estudo ambiental mais amplo da bacia, conclusão, aí começou uma gritaria aqui, a ponto de eu fazer um artigo pro jornal, dizendo que eu fechava totalmente com o pessoal da Secretaria do Verde, e estou sabendo que o pessoal tá sendo pressionado lá, eu falei para o pessoal do Decont, vocês contem comigo, se o pessoal da comunidade ligar pra vocês, pressionando, vocês mandem falar comigo, porque quem representa a região sou eu.

Quando o Kassab falou que ia dar 70 anos a mais ainda, porque a nossa ideia era que isso aqui virasse dois parques urbanos, o Decont também era favorável, o centro de treinamento do São Paulo e do Palmeiras, você soube que o Kassab mandou na sequência, pra Câmara, um projeto de lei, dando mais 70 anos para os clubes, mas eu acho que não foi aprovado totalmente, e aí, quando isso aconteceu, a gente mandou pro Ministério Público, com toda essa documentação.

Isso aqui é uma coisa interessante, nós estamos nos reunindo aqui, a sociedade civil, a cada coisa que acontece, eu faço uma reunião técnica com eles e nós estamos monitorando as exigências, por isso que está dando esse rebu, a sociedade civil está monitorando todas essas exigências, a gente está sistematicamente vendo se estão sendo cumpridas ou não. Quando tentam não cumprir, nós estamos atuando pra que isso seja obedecido.

Clayton: Quando a participação da sociedade civil se intensificou? 
Sra. Ros Mari Zenha: Começou, basicamente, quando nós começamos a participar mais ativamente do CADES, eu acho que essa participação da sociedade civil no CADES, pelo menos aqui, na nossa região, foi muito promissora, começou que eu tomei posse, eu fui eleita pro CADES, estou na segunda gestão, nós estamos em 2012, foi em 2009 que eu tomei posse na primeira gestão e aí nós começamos a fazer um trabalho mais integrado com os grandes movimentos da cidade.

Só que já existia uma conexão, já existia, vamos dizer um clima, por conta da discussão do Plano Diretor, então quer dizer, em 2006 devia ter tido a revisão, aí na época era o Serra, o prefeito. Ele mandou o projeto para revisão e ele estava misturando as duas coisas, o Plano Regional Estratégico e o Plano Diretor. E o Regional Estratégico envolve o zoneamento e isso não estava previsto nem na lei, que também seria uma forma de você burlar, porque numa mesma discussão, a população não estava se dando conta, começou aí essa luta, aí em 2006; 2007, então, todas as entidades, juntaram duzentas entidades e nós entramos com uma ação civil pública no Ministério Público contra a revisão do Plano Diretor de 2006, e aí a justiça, o Ministério Público acatou, mandou pro tribunal e o juiz falou: pode parar, o senhor está misturando alhos com bugalhos e portanto está suspenso.

Conclusão, a prefeitura tomou uma derrota fragorosa, e eles puseram o pé no breque e nós começamos então, todo mundo a se mexer, aí surgiu a eleição do CADES...

Clayton: o CADES é uma coisa nova?

Sra. Ros Mari Zenha: ele foi criado na época da Marta, acho que a primeira presidenta do CADES foi a Stela Goldstein, que era secretaria na época da Marta, e aí eu entrei nessa época, os CADES regionais são novos, não estou falando do CADÃO, da Constituição de 88 que exige que tenha os conselhos e tal, aí foi que com essa participação começou a juntar vários movimentos e a Zona Oeste foi privilegiada, porque aqui a gente tinha atuando fortemente o Movimento Defenda São Paulo, que até então eu fazia parte da diretoria, acabou meu mandato agora de diretoria de meio ambiente, Movimento de Defesa do Parque da Água Branca, que também teve um belo de um trabalho defendendo o Parque da Água Branca do ataque de destruição a que foi sujeito na época da mulher do Goldman, que resolveu tirar a característica rural que o parque tem, aí muita gente esteve envolvida nessa luta, juntou também com o MOVER, que é um Movimento contra a verticalização aqui da Lapa, juntou com o preserva São Paulo, que é outro Movimento de preservação do Patrimônio da cidade.

E com isso o pessoal continua todo mobilizado, tanto é que a gente tenta, sempre que tem uma novidade, fazer reuniões técnicas com eles, a gente faz no auditório da Água Branca, explicando o que está acontecendo.

Clayton: O Movimento Água Branca é uma coisa e o Movimento Parque Água Branca é outra coisa?

Sra. Ros Mari Zenha: Eu acho que é uma mesma coisa. Tem dois: é movimento dos moradores da Água Branca e Movimento do Parque, é a mesma turma que participa, com a Jupira, com a Cira, a Ilma, é todo aquele pessoal lá da Água Branca né, é o mesmo pessoal.

E aí nós tivemos sorte porque conseguimos pegar um pessoal combativo, enfim, que trabalham em instituições de pesquisa ou em universidade, isso sempre ajuda. Um Movimento muito igual a esse tá ocorrendo lá na Vila Sônia.

Clayton: E sobre o pessoal que mora na favela?

Sra. Ros Mari Zenha: Bem lembrado, eu tenho bastante claro e acho que o Movimento todo também tem, a Jupira, todo mundo que tá envolvido, que é o seguinte, até por uma questão de postura política mesmo, que é a minha, eu sempre lutei por uma cidade inclusiva.

Acho que uma cidade inclusiva, ela tem que ter no seu território, diferentes faixas de renda, tem que ter convivência entre diferentes faixas de renda, eu sou totalmente contra guetos, eu acho que você tem que viver numa diversidade, isso é a democracia, e no caso aqui da Operação Água Branca nós levamos uma luta que foi, acho a que tenha me dado mais trabalho.

Nós tínhamos aqui no perímetro da Operação Urbana Água Branca, duas favelas, a favela Aldeinha e a favela do Sapo, obviamente que você poderia me perguntar, num bairro nobre como é a região da Lapa, ter favela em beira de córrego, que é o caso da favela do Sapo e a Aldeinha que ficava lá por baixo dos viadutos, poderia falar: o pessoal tende a querer expulsar, 
ver esse pessoal longe, e infelizmente, antes da gente entrar no Movimento, quem era subprefeita aqui da Lapa era uma tal de Soninha Francine, de triste memória, ela assume uma pseudo postura de progressista, mas quando ela esteve aqui como subprefeita, a favela da Aldeinha foi escorraçada, a prefeitura veio e colocou os caras para correr dando 3.000 reais pra voltar pro seu lugar de origem.

Quando nós entramos no Movimento, tinha a favela do Sapo e a favela do Sapo fica em cima de um córrego e no entorno dela você tem o Cingapura, feita pelo Maluf, e tem um monte de casinhas da época dos mutirões da Luiza Erundina, nós começamos a nos envolver com a favela do Sapo e a primeira coisa ao olhar a norma e analisar profundamente a Operação Urbana Água Branca do Maluf, eu fui recuperar toda a legislação, o que que lá dizia, que todo e qualquer desalojamento de população pobre de assentamentos precários no perímetro de atuação da Operação Urbana Água Branca, tinha que haver a garantia de uma solução habitacional pra eles, no próprio perímetro, lógico que naquela época essa região não tinha o valor de mercado que tem hoje, agora imagina se alguém está interessado em destinar qualquer terrinha para o pessoal. Nós tivemos inúmeras reuniões com a favela, várias, eu cheguei a fazer assembleia de sábado a tarde com todos os favelados, organizando a turma, inclusive com os mutirões da Luiza e do Cingapura, falei, vocês fiquem atentos, vocês vão ser a bola da vez, que é uma área privilegiadíssima e outra, subindo três torres de altíssimo padrão ao lado, onde o muro já está construído, eu falei aquela turma não vai estar nem um pouco a fim de ter no horizonte uma favela, eles são vizinhos dos Centros de treinamento, atrás da Telha norte.

Eles estavam na beira do córrego e aquilo é área de risco e o mapeamento de risco, inclusive, quem faz é o IPT e eu tive uma reunião com eles, falei, vocês estão em área de risco, não adianta, vão ter que sair daqui, aquele córrego enche, não tem condições deles estarem ali e é palafita, bom, conclusão foram inúmeras reuniões.

Eu peguei o material, eu e a Jupira, o material da época do Maluf, fomos à defensoria pública, tivemos três reuniões acho com as defensoras públicas, fomos no Ministério Público com o Dr. Freitas, explicamos pra ele e falei: Dr. Freitas não da pra deixar eles com esse papel na mão da secretária Elizabete França, porque eles pagam bolsa aluguel e falei, qual que é o papel que eles tem na mão que vão poder voltar para o perímetro? Porque a Operação Urbana Água Branca pretende fazer moradias pra HIS e pra mercado popular, por isso que nós estamos trabalhando com um subsolo só e, que dê, eu sempre falei, gente, o pobre não precisa morar numa unidade habitacional em Itaquera nem no Cingapura, eu conheço projetos de moradia popular feito na América Latina lindíssimos em termos de projeto arquitetônico, né, não é porque a pessoa tem essa mania de achar que vai ter uma Cidade Tiradentes ou aquele Cingapura terrível do Maluf, não, você pode trabalhar com prédios de até 4 andares, não tem porque o pessoal não poder ficar aqui no perímetro, aí fomos lá, demos um texto, o Ministério Público olhou, um texto muito rebuscado, que desse a garantia legal pra eles, de que eles vão ficar aqui no perímetro, lógico que eles estão com a bolsa aluguel, não podem ficar na beira do córrego, mas tem um documento jurídico, formal, de que, eu falei vocês guardam isso num quadro, pelo amor de deus vocês não percam isso, e aí tivemos 4 reuniões com a Bete França ${ }^{78}$, e aí, foi numa dessas reuniões que teve um arranca rabo, porque eu falei pra ela, eles não saem se a senhora não aceitar o documento como ele está aqui, eu falei, foi visto pelo Ministério Público, tem que voltar pro perímetro, segundo a lei tal e tal e tal e tal, já está na lei, mas nós queremos que ponha aqui no papel, e a comissão dos favelados juntos com a gente.

E aí nós conseguimos acertar isso, eles assinaram toda a documentação, eu levei no Ministério Público, a Jupira tem tudo isso controlado, nós fomos mapeando um a um que saia de cada barraco, para onde ia, sabemos todos, todos. Pra onde foi, pra onde não foi e o Emerson tomando conta. E garantimos inclusive que não ia ser ocupada de novo a beira do córrego. Tanto é que agora já está lá a "Operação Córrego Limpo", já estão arrumando tudo e agora estão todos organizados com as casinhas ali, eu falei, fiquem espertos, depois não venham reclamar, porque depois chega alguém aqui e oferece 10.000 reais pra comprar a casinha, o cara vende, eu

\footnotetext{
${ }^{78}$ Funcionária da Secretaria Municipal da Habitação.
} 
falei, gente fiquem espertos, vocês moram numa área nobre, $\mathrm{o}^{2}$ aqui custa fortuna, esse negócio vai virar um polo fantástico, nossa, imagina pra quanto vai o preço da terra ali.

Conseguimos inclusive que eles reformassem o Cingapura, junto com o Ministério Público, estava tudo vazando, eu falei, Jupira, eles vão apostar na deterioração, aí fomos lá, a Jupira fotografou todas as patologias do prédio, vaza água aqui, sai esgoto ali, mandamos todas as fotos pra Secretaria da Habitação, vieram, estão arrumando. Quando que os caras vão arrumar pra alugar por 300 reais aqui, nem barraco de favela!

Então veja essa questão da habitação de interesse social, pra nós, Clayton, é um ponto de honra, não só mantê-los aqui, como a Operação Urbana Água Branca ter HIS, quando eu falo HIS é que vai de zero a três, que atenda essa faixa de renda mais baixa da população, que é onde tá a grande carência de moradias. E outra atende até seis salários mínimos e depois a chamada faixa de habitação de mercado popular, que hoje vai até dez, que é a chamada classe média baixa, quer dizer, essa região tem que estar sendo destinada a essa faixa de renda, esse é o meu entendimento pra cidade compacta. Para que eles saiam, essa turma toda que trabalha no telemarketing aqui na Leopoldina, eles vem todos da periferia, vem lá de Itaquera, vem lá de Campo Limpo. Agora, isso vai ser uma luta, a hora que isso chegar na Câmara.

Porque, qual que era a ideia, nós fechamos toda a área técnica, prédio com limites de gabarito na altura, no máximo 1 subsolo, privilegiando o transporte coletivo, porque é uma região que vai estar muito bem servida por transporte coletivo, privilegiando o espaço público em detrimento do espaço de moradia individual, que você possa ter mais equipamentos públicos e nossa ideia era ter dois grandes parques, não só pra nossa região, mas pra cidade, que era o centro de treinamento do São Paulo, o centro de treinamento do Palmeiras, que termina agora, em 2020, a concessão, a ideia era a partir daí tornar aquela área dois parques públicos, área da Fábrica dos Sonhos.

Isso vai ser uma luta, a hora que isso entrar na Câmara, dependendo de como vier a se compor a Câmara, isso é uma coisa que tem que passar por um Projeto de Lei, mas eu acredito que a gente tenha condições de defender isso no CADES, de estar defendendo isso junto ao Ministério Público, quer dizer é uma coisa desgastante, nós estamos ficando muito cansados porque ao contrário do trabalho dos lobistas do mercado imobiliário, eles estão em todos os Conselhos, só fazem isso, ganham pra fazer isso, agora nós não, nós da sociedade civil tem que trabalhar, trabalhar o dia todo, ainda vai nas reuniões, fim de semana monta os relatórios, quer dizer, é jogo duro. Por isso que nós estamos aí criando o Fórum Partidário, acho que a gente tem que fazer uma cunha mesmo da sociedade civil na Câmara, lá no espaço legislativo e agora vamos ter que nos fortalecer e vamos estar levando esses debates lá, se eu puder discutir isso lá dentro a gente economiza muita energia.

Então, eu acho que a gente tem que estar dessa forma, participando dos Conselhos, qualificando nossos representantes, por isso que nós estamos fazendo reuniões técnicas da região, a pessoa tem que entender, hoje ele sabe, por exemplo, o que é lençol freático, eu chamei técnicos do IPT pra dar aula aqui. Um falou do lençol freático, o outro falou das mudanças climáticas, o que pode afetar.

Então essa é a ideia, Clayton, e vamos tocando com a esperança que a gente tenha o melhor prefeito.

\section{APÊNDICE C}

Entrevista realizada em 07/05/2013 com Toninho Vespoli, único vereador a votar contra o PL Operação Urbana Consorciada Água Branca.

Clayton: Segundo lideranças da sociedade civil, eles conseguiram avançar muito na revisão da Lei da Operação Urbana Água Branca e quando o Projeto de Lei veio para a Câmara Municipal de São Paulo, havia um receio de os vereadores não a aprovarem, no entanto foi aprovada na primeira votação. O senhor foi o único vereador a votar contra, por que? 
Toninho Vespoli: Então, eu fui contra por alguns motivos, primeiro, é um projeto que já estava andando aqui na casa, a gente teve na eleição agora, $40 \%$ de renovação, mas tiveram alguns vereadores que viraram secretários e alguns suplentes entraram, então praticamente nós estamos com metade dos vereadores novos na casa, então, esse projeto já vinha andando e quando chegou na conversa dos líderes dos partidos, porque é assim, aqui na casa tem reunião de liderança de partido, cada partido elege um líder que participa de uma conversa, acho que aqui deve ter treze partidos, então é uma reunião de treze vereadores, cada um representando o seu partido e como do PSOL eu sou o único, eu sou o líder de mim mesmo e vou na reunião de lideranças representando o PSOL.

Nessa reunião de liderança, o governo colocou para votar, mas, se não me engano foi a pedido do Paulo Frange, e como eu me posicionei, eu e mais três vereadores, um líder do PMDB, o líder do PPS e não vou lembrar agora o outro líder, mas quatro líderes se posicionaram neste sentido... ah não, o Ricardo Young foi, mas ele não é líder, ele não vota, aí a gente colocou o seguinte: é uma lei complexa e que os 50\% dos vereadores que estão chegando na casa não teve tempo de vê. Porque se você for ver a pauta da casa, existem duzentos e tantos vetos do governo passado para ser votado que fica na pauta e não porque fica na pauta que vai ser votado, e é na reunião de liderança que a gente acaba discutindo o que entra na pauta e a gente vê o que está na pauta da semana. Aí entra um Projeto de Lei dessa complexidade em que 50\% dos vereadores, eu te garanto, não tem a dimensão do que é o Projeto, inclusive eu não tinha, isso eu deixei claro na reunião de liderança, mas o governo, por vários motivos, que quem deve falar é ele, insistiu para colocar na pauta e como ele tem maioria na Câmara, os líderes se posicionaram para votar naquele dia. Então essa foi a primeira questão.

Outra questão que a gente votou contra, é pelo aumento do poder construtivo na região, você vai aumentar em $600.000 \mathrm{~m}^{2}$ o poder construtivo na região e o que é pior, não conta a construção de estacionamento, não é considerado, por exemplo, os corredores de prédio, várias questões não são consideradas como área construída, então o poder construtivo acaba sendo maior do que os $600.000 \mathrm{~m}^{2}$, e acaba adensando uma região sem a infraestrutura necessária, então você vai abaixar a qualidade de vida naquela região para as pessoas que moram naquela região, ou seja, na questão da locomoção das pessoas, por exemplo, tem um empreendimento que vai acontecer naquela região que só aquele conjunto de prédios vai trazer doze mil pessoas em uma área bem restrita, já venderam, acho que três blocos de prédio de entorno de vinte ou vinte e dois prédios, uma coisa assim, aí eles falam, mas aqui tem acesso ao viaduto, que já é entupido na hora de pico, aí você vai colocar doze mil pessoas, quer dizer, eles não pensam na questão das escolas, aquelas pessoas vão estudar aonde? É quase um mini bairro que eles estão trazendo e tem a questão dos postos de saúde, os hospitais, não tem nenhum planejamento e a gente está a mercê aqui da especulação imobiliária, do poder do SECOVI e dessas construtoras. E aí a cidade tem que se adequar à vontade desses senhores, que simplesmente querem ganhar lucro e desestruturam toda a nossa cidade.

Para você ter uma ideia, a OMS fala que tem que ter doze $\mathrm{m}^{2}$ por habitante de área verde, na Operação Urbana vai ter 3,6 $\mathrm{m}^{2}$ de área verde por habitante e que é mais um absurdo porque ali é uma área de várzea, então você teria que ter muito mais área verde para não impermeabilizar o solo, para você dar outras condições para aquilo ali não virar o que é... você vê quando tem enchente, qual é o volume de água que tem ali, em vez de se pensar ao contrário, se pensa só na lógica do mercado imobiliário, e isso acontece, não é à toa, isso acontece porque tem fortes relações nas campanhas eleitorais, eles financiando vários candidatos a prefeito ou financiando vários candidatos a vereadores. É uma lógica de poder, a gente tem os três poderes, o executivo, o legislativo e o judiciário, mas não é só isso, você tem outros poderes que às vezes estão mancomunados com esses poderes que vão dando essa lógica de mercado.

A Operação Urbana hoje, nada mais, está servindo para aumentar o potencial construtivo, por exemplo, a Água Espraiada, o que o governo pegou de dinheiro para poder aumentar o potencial construtivo além do permitido, não foi suficiente para dar a infraestrutura, o governo teve que bancar mais dinheiro naquela Operação Urbana. O que eu quero te falar é o seguinte: a lógica do mercado é tão grande que eles acabam por desviar e desvirtuar leis, eles conseguem achar brechas em vários artigos. Eu fui em uma dessas reuniões da revisão do Plano Diretor e meu 
assessor sentou atrás do pessoal do SECOVI e a conversa deles era: a gente vem nessas reuniões, isso é uma perda de tempo, se passar alguma coisa que restrinja a nossa capacidade de pensar a cidade como a gente pensa, a gente já está protocolando um monte de empreendimentos, porque depois se passar um Plano Diretor que tenha alguma dificuldade para a gente, a gente vai para a justiça porque a gente já protocolou um monte.

Clayton: As lideranças na sociedade civil dizem que os grandes aliados são os técnicos, que os ajudam entender os impactos, e o Ministério Público. Por que não o legislativo?

Toninho Vespoli: Acredito que seja por conta dos financiamentos de campanha, é ruim falar dos outros colegas, mas, alguns vereadores, por exemplo, estão muito ausentes na casa, mas, para votar determinados projetos eles aparecem. Na verdade, tem interesses nessas votações importantes. A maioria dos vereadores estão atrelados com segmentos que financiaram, seja na área de transporte, seja com os empreiteiros, é um sistema capitalista, se eu chego para você todo mês e te dou vinte mil reais, eu nem preciso falar para você, você mesmo vai colaborar e não travar determinadas questões, isso é complicado.

\section{APÊNDICE D}

Entrevista realizada em 19/04/2013 com Asunción Blanco, assessora do vereador Andrea Matarazzo, presidente da Comissão Técnica de Política Urbana, Metropolitana e Meio Ambiente.

Clayton: A senhora pode fazer uma análise de como vem sendo aplicada a Operação Urbana em São Paulo?

Asunción Blanco: Na realidade, é assim, a Operação Urbana não é uma criação brasileira, esse tipo de intervenção começou na França e a proposta era a recuperação de alguma área degradada. Então, a primeira discussão que tem em relação as Operações Urbanas aqui, é que as áreas propostas são gigantescas, então começa a aberração por aí.

A primeira discussão que tem é: isso é uma Operação Urbana ou é uma venda da cidade? Porque a Operação Urbana sai fora de toda e qualquer legislação proposta no Plano Diretor. Então têm umas brechas, umas licenças que não tem em outras áreas. A própria Operação Urbana, ela começa com quatrocentos quilômetros, agora já está em quatrocentos e cinquenta, ela vai de uma ponta a outra da cidade.

A outra questão que também está em discussão e a gente aí vai falar, em termos gerais de qualquer O.U. aqui, é que se fez uma, que é a Faria Lima e não se voltou ela para saber o que foi bom o que não foi, o que funcionou o que não funcionou, o que deu certo o que não deu, para aí sim, ver e avaliar as outras, mas, não, a gente já vai fazendo uma em cima da outra e ninguém mais sabe quem é quem.

A OUCAB começa na época do Mafuf, então você imagina desde quando se discute isso. A gente fica discutindo a cidade em pedacinhos e quando a gente vai colar um pedaço com o outro não dá, não amarra. Isso tem que estar dentro da discussão.

Hoje a gente tem esse problema que, estão aprovando ou entrou em votação a O.U., por outro lado a gente vai começar a discutir Plano Diretor, que ela teria que estar dentro e por outro lado tem um projeto de lei aqui na Câmara rodando de um vereador que quer ampliar o prazo de cessão de área pública para o São Paulo Futebol Clube, uma área que já está proposta na OUCAB para virar parque, aí se aprovam isso, faz como? Como se enfia isso dentro da OUCAB, como fica o parque? Então é isso, por que não se discuti as coisas em conjunto? Por que não se levanta o que está em andamento naquela região? Por que não se para tudo aquilo para uma discussão única?

Clayton: existe uma reclamação de lideranças da sociedade civil, de que a arena multiuso Palmeiras, a Fábrica dos Sonhos e essa área utilizada pelos clubes do São Paulo e do Palmeiras estão fora da discussão, mas estão dentro do perímetro da OUCAB. Diante disso, eles dizem 
que os dois grandes aliados são os técnicos que orientam sobre os impactos e o Ministério Público, que é para onde eles levam reclamações e denúncias. E o legislativo? Por que não é visto como aliado?

Asunción Blanco: Essa é outra questão que a gente deveria abordar. O legislativo muitas vezes é atropelado pelo executivo. Ele vem e impõe, ele tem maioria, porque é assim que funciona, sempre o legislativo é maioria do executivo, então ele já entra vencendo. Então o legislativo, que legislativo? E na realidade o Ministério Público sobra para a sociedade civil como última possibilidade. Eu, particularmente, se fosse o representante do Ministério Público, ia começar a cobrar de outra maneira, eles ficam acumulando uma série de trabalhos porque todas as outras instâncias não funcionaram. Não funcionam as Subprefeituras, não funciona a ouvidoria e quando chega na última possibilidade ela recorre exatamente ao Ministério Público e isso é outra aberração. Por que lotar de casos que poderiam ser resolvidos antes? As pessoas acabam judicializando a questão.

A última reunião da Comissão Técnica de Política Urbana, o próprio membro da Comissão, que é do partido do executivo, declarou que ele foi surpreendido com o projeto aqui na casa para aprovação, ele não passou pelas Comissões, ele foi aprovado por conjunto de liderança e a oposição, que é minoria, foi vencida. Então a gente tem que olhar para o funcionamento de legislativo, que dá brechas para que isso aconteça.

Clayton: No site da Câmara tem a informação que só o vereador Toninho Vespoli do PSOL votou contra a aprovação do projeto.

Asunción Blanco: Mas não foi bem assim. A liderança do PSDB também foi contra, mas, foi voto vencido.

Clayton: Houve avanços na revisão da Lei?

Asunción Blanco: Na realidade, para mim, eu não estou representando ninguém agora, não houve avanços, quando não se faz essa discussão dentro do bojo maior, que é o Plano Diretor, então não tem avanços, a gente continua discutindo picado e ainda dentro desse picado tem outras série de coisas.

O próprio pessoal da favela que tinha na região, não estava sendo acolhida pela O.U., agora, ainda está, na segunda revisão, quando fez o estudo do EIA-RIMA, fora que eu acho uma aberração o tamanho, quatrocentos e cinquenta quilômetros é muita coisa. Não está sendo discutido no macro, então vamos discutir a arena do Palmeiras separado, vamos discutir o C.E.T. do São Paulo separado, vamos discutir a favela separado, vamos continuar no separado e a gente não vai conseguir juntar nunca nada.

Na época do shopping Bourbon, autorizaram fazer um shopping e já tinha outro perto, já tinha a Vila Country que trazia um trânsito absurdo para o lugar, aí autorizaram aquelas torres todas de escritório, ou seja, numa mesma avenida já tinha uma quantidade absurda de coisas, isso sem contar agora com a arena Palmeiras, a gente está falando só de dois quarteirões e já tem todo esse problema, você imagina quando vier tudo isso. Não dá para pensar a cidade desse jeito.

Sem contar que tanto essa, quanto a próxima, que é o arco do futuro, ela está na várzea do Tietê, todo mundo sabe que a várzea é exatamente o lugar que você não deve fazer nada, que é para a vazão do rio, vamos ter de novo o que? Enchentes?

Tem um conceito errado sempre que você vai discutir essas coisas, porque as pessoas falam: mas, você é contra o desenvolvimento, o preservacionista virou agora um xiita, entendeu, e por mais que você dê informações técnicas de subsolo e assim por diante e problemas de drenagem e tudo, sempre você é equivocado, você não quer o desenvolvimento, você é um atrasado. 


\section{APÊNDICE E}

Entrevista: vereador José Police Neto, membro da Comissão Técnica de Política Urbana. 07/05/2013.

Clayton: Em relação a Lei de 1995 que cria a Operação Urbana Água Branca e o Projeto atual, que propõem mudanças, quais foram os avanços e o que precisa avançar?

Police Neto: Não é que teve ou não avanço. Você tem uma obrigação de fazer esta Operação à luz das inovações trazidas pelo próprio Estatuto da Cidade. Então, se você pega a modelagem da Operação Urbana Original, ela é anterior ao Estatuto da Cidade e, portanto, ela pouco atende a gestão democrática, ela pouco atende as regras de transparência, ela é muito frágil na formalização que você constrói para informar a sociedade qual é o plano urbanístico específico que vai ser implantado naquela região, quais os recursos que serão produzidos a partir do direito de chegar até o coeficiente máximo estabelecido na região, ela pouco se setoriza, portanto você tem o risco de não se implantar um espaço, uma paisagem urbana que seja desejada pela população. Então de um momento para o outro você tem avanços significativos, seja pela recepção do Estatuto da Cidade, seja por inovações que a própria Operação trouxe, mas, ainda precisa um debate bastante acurado com a população para que ela também enxergue isso não é. Ela não pode ser um avanço do ponto de vista técnico, mas não ser um avanço do ponto de vista social, então... ah avançou porque agora você condiciona o uso do CEPAC, é..., o empreendedor que for realizar, tem que realizar, média e alta renda, mas baixa também, isso é um avanço? É, é um avanço, você rediscutiu a questão de garagem, você passa a não ter só mínimo, você pode ter em alguns casos, teto, portanto você pode não ter garagem. Avança bastante nesse debate, mas ainda é pouco perto daquilo que a população se recente, que é: como que vai ficar o meu território? Por isso que é muito importante essa setorização o mais detalhada, mais setores, subsetores, porque vai ter lá doze, quinze quadras e o morador que ali mora consegue enxergar o que vai acontecer, talvez essa seja uma das questões fundamentais, a população precisa enxergar o que ela vai receber depois que a Operação urbana tiver sendo implantada. O recurso que é construído, que é projetado na própria Operação, então quando chega o projeto aqui na casa você consegue calcular, uma das questões que a gente está discutindo muito com o executivo é como colocar valor nas despesas, já que você criou a receita e você põe lá um monte de intervenções de estrutura, de viário, de saneamento, de drenagem, de áreas verdes, de passeios públicos, não é possível você avançar e colocar o custo dessas intervenções? E você minimamente colocar o que é prioritário, para fazer aquilo que a população anuncia como prioritário, então o recurso ingressa no cofre da prefeitura e a prefeitura vê o que a população já colocou como prioritário, então essas são as questões que a gente ainda pretende avançar no estágio que chegou até aqui.

Clayton: As lideranças na sociedade civil dizem que os grandes aliados são os técnicos, que os ajudam entender os impactos, e o Ministério Público. Por que não o legislativo?

Police Neto: Você tem que perguntar para eles e você vem aqui me perguntar. Eu tenho tentado ser um aliado, tentando dar transparência às atividades do executivo, acho que a democracia é mágica por conta disso. Todos esses que não recorrem a gente, eles vão às urnas, talvez tenham que fazer uma reflexão sobre isso, mas é uma reflexão deles, a gente vai continuar aqui oferecendo nossos estudos, nossos trabalhos. Quem sabe se eles tivessem uma rotina de vir mais aqui, como eles vão ao Ministério Público eles teriam uma visão da Câmara igual a que eles têm do Ministério Público.

Clayton: Em relação ao conjunto da cidade, esta Operação Urbana pode ser um exemplo para outras áreas? E como fica em relação à discussão que está sendo feita em relação ao Plano Diretor?

Police Neto: Ela tem essa característica de ser gestada 100\% após o Estatuto da Cidade, a Operação urbana Água Espraiada é de 2001, surge quase concomitante ao Estatuto da Cidade, ela aproveita os instrumentos, mas não conseguiu refletir sobre eles, então essa vai ser a primeira, a última Operação Urbana aprovada é de 2001, da Água Espraiada, que foi revista em 2003; 2004; mas essa é a primeira que é gestada 100\% nesse período, gestada num momento que há uma aversão à verticalização, então a sociedade reage, muitas vezes contra a 
verticalização porque nosso Plano Diretor produziu um incentivo absolutamente indiscriminado à verticalização, então o debate entre 2002 e 2004 aqui nesta casa, que também não participei, produziu um incentivo à verticalização residencial que permeia quase toda a cidade, embora a gente elogie muito o Plano, a gente tem que reconhecer que o Plano deu um incentivo desmedido, mais do que isso, colocou nas zonas mistas três, uma autorização gratuita para também se construir uma vez a mais o que o proprietário já tinha e verticalizando, então, infelizmente, o debate 2002-2004 acabou por revelar sem muitos conseguirem notar um incentivo quase que absurdo à verticalização e a gente sofre com isso agora, o Plano vem sendo endeusado, mas quando você olha ao pé da lei, a letra da lei incentiva muito a verticalização. $O$ que a gente precisa é não só refletir o modelo de cidade que queremos, a cidade compacta, que as ofertas do sistema de circulação tem que contabilizar um adensamento populacional para você usar com eficiência, mas o equilíbrio urbano você tem que oferecer áreas verdes, tem que colocar a questão de água, energia, esgotamento sanitário, então tem uma série de inovações que tem ser trazida para esse cálculo de moradia, que até hoje não foi feito. É uma lição de casa gigantesca para a gestão pública. 
ANEXO A

\section{Nova fronteira imobiliária}

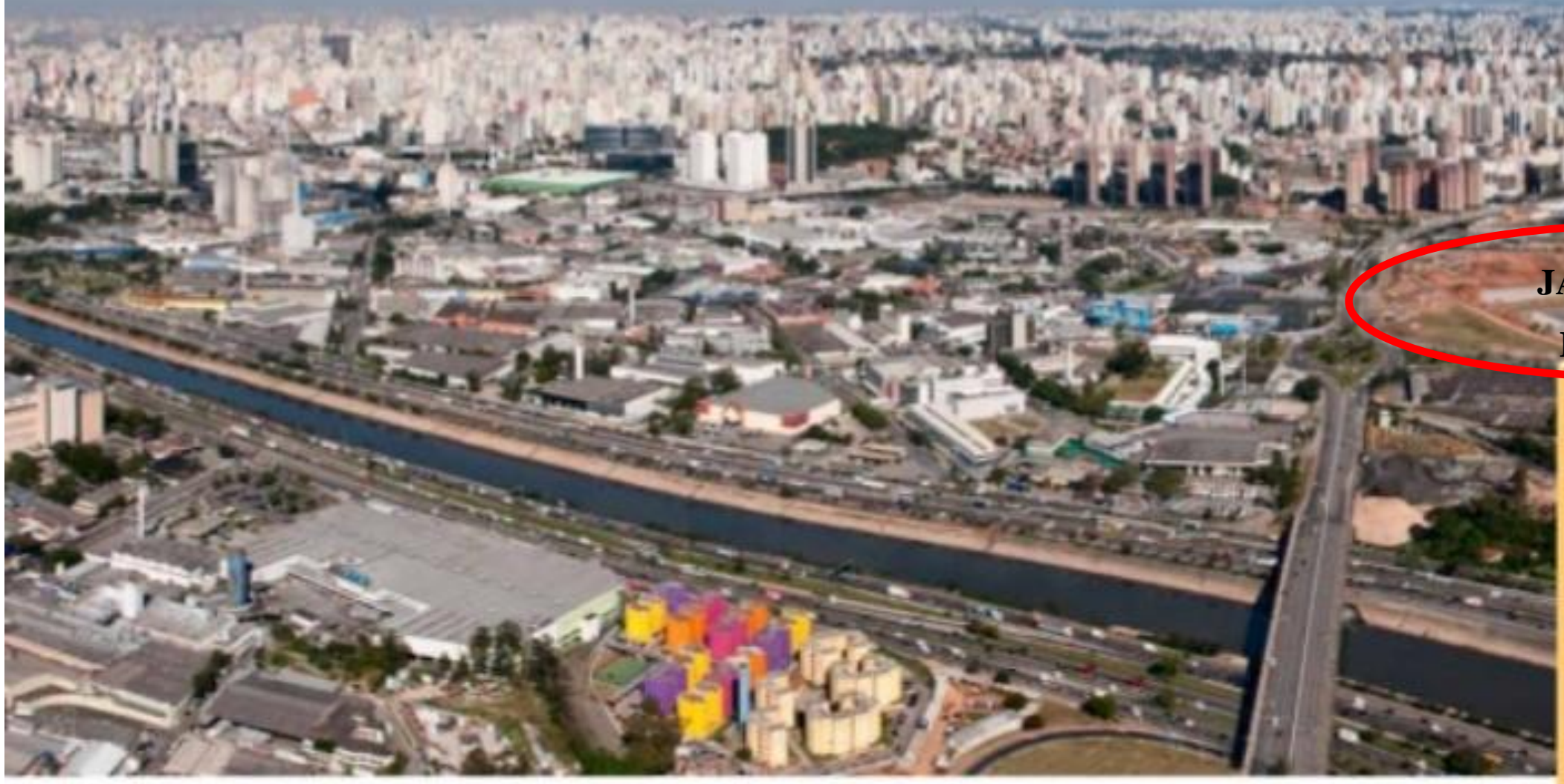

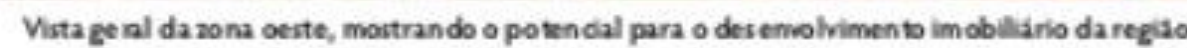

VÁRIAS ÁREAS DE SÄO PAULO MOSTRAM POTENCIAL COMO POLOS DE ATRAÇÃO

regiäoque ahrange Perdizes, Pormpeiae Ba ma Funda, nazona a cesk de Sio Prubo,esti se vomando um polo de atraça imo grandes shapping cenkers (West Plaza, ma Água Branca, e Bourban. na Pompeia) edos fonuns de lustica na Burra Funda. a km da perspec. tiva de revitalizacio e desenvil vimento represcnteda por operacoues

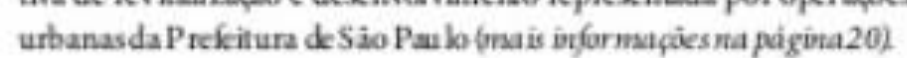

6 mes sho ave
VALORIZAÇÃO DO
ENTORNO EM 5 ANOS

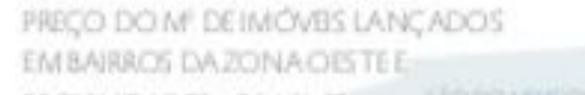

PrCOTIML

200

- 2011

(1) (2) (1) (3)

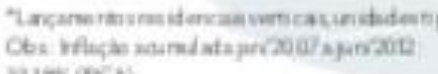

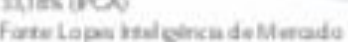

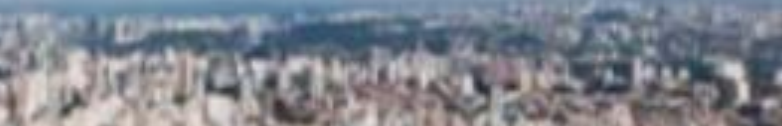

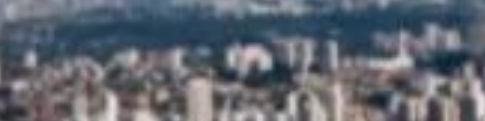

sondo Titididy

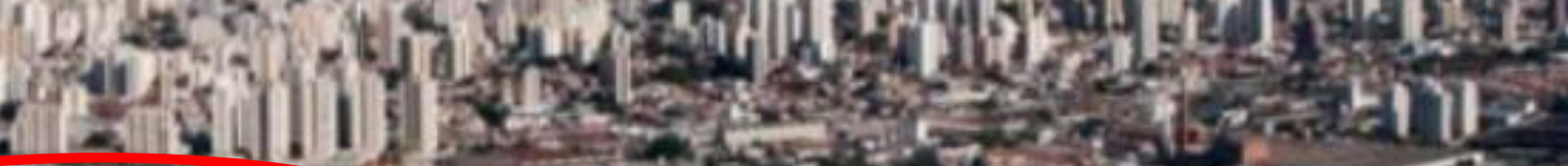
JARDIM DAS

PERDIZES - 2 -
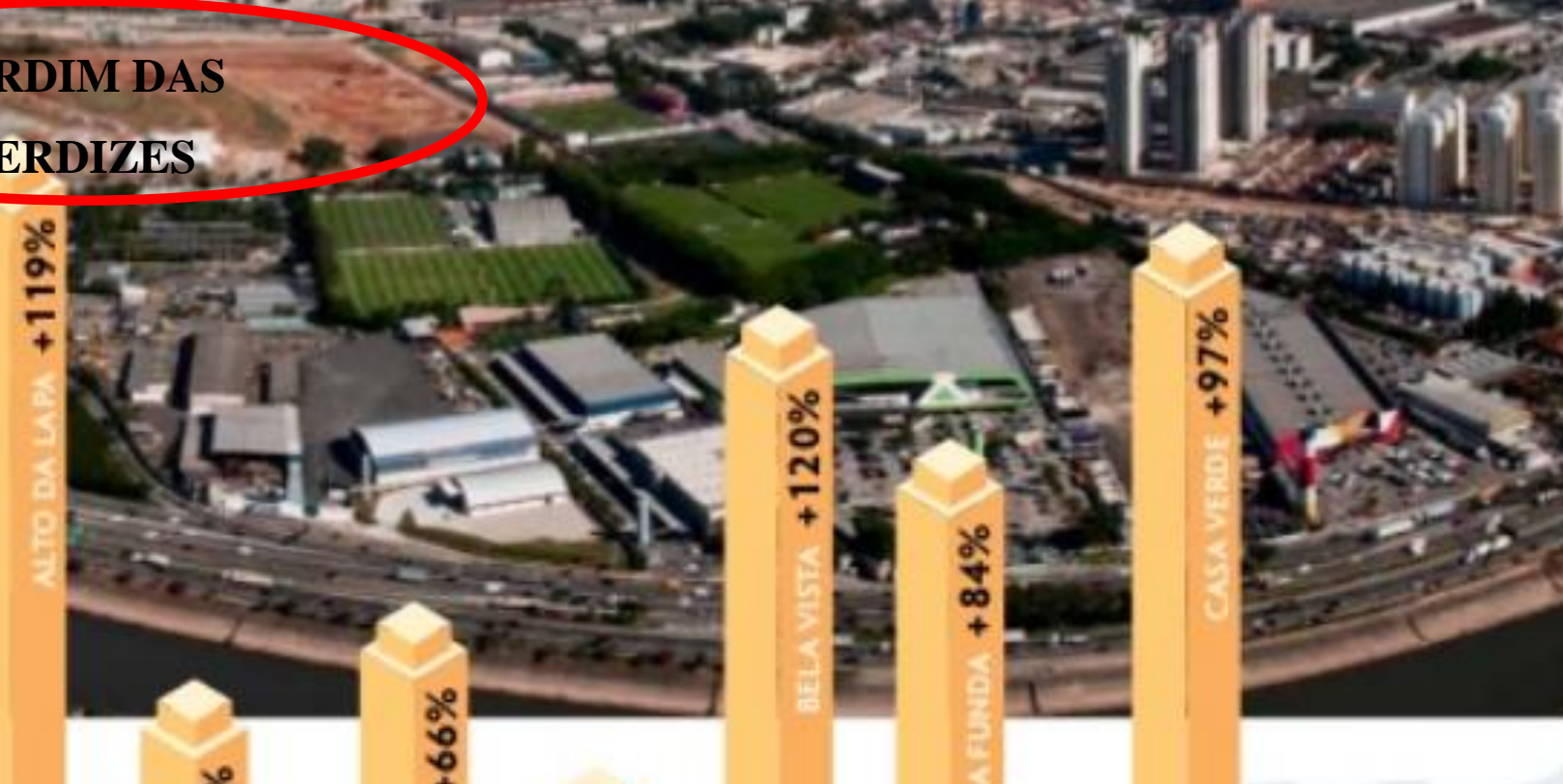

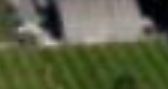
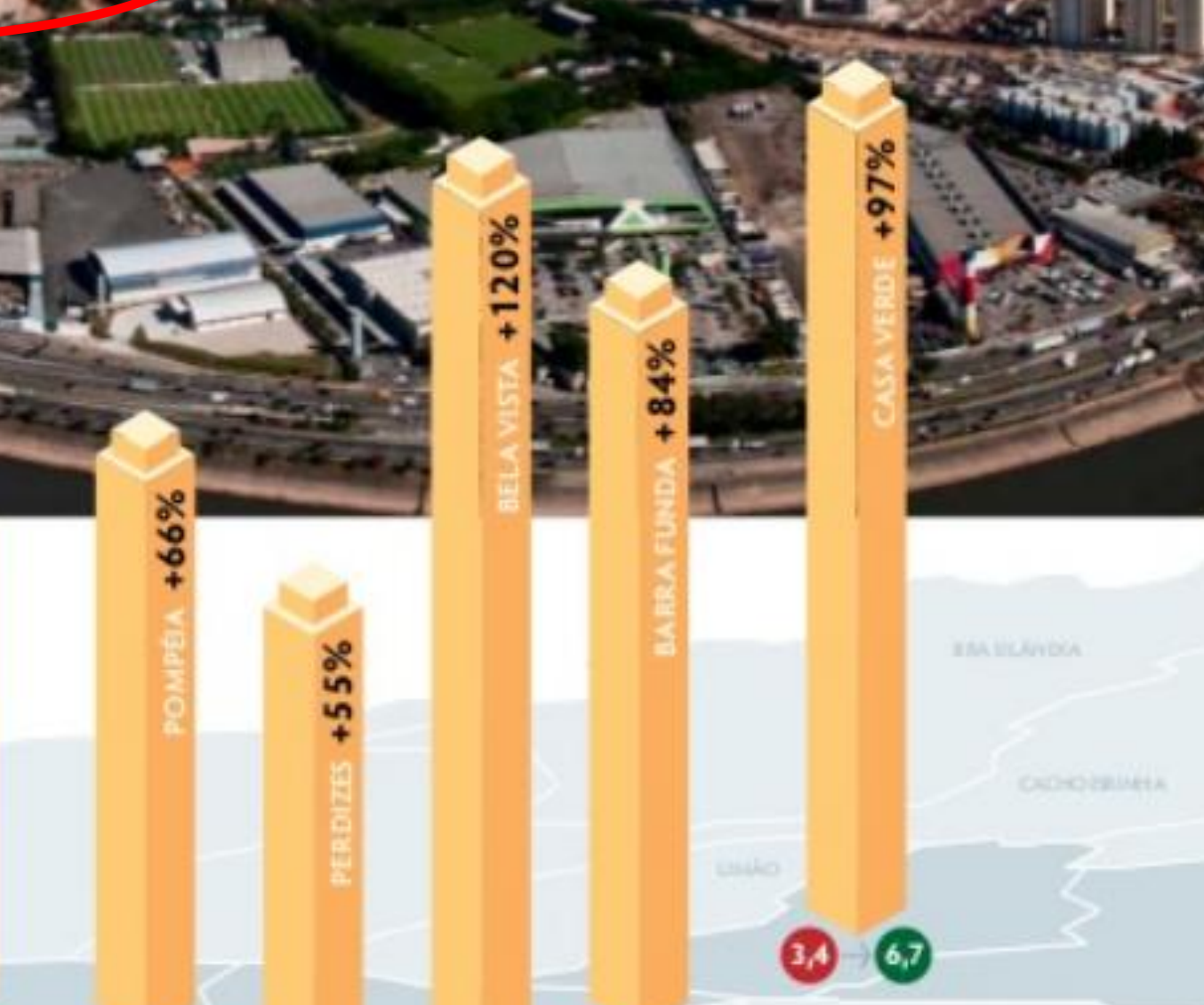

Fonte: Revista Viver São Paulo, Editora Contadino, 2013. Disponível em: 〈http://www.jardimdasperdizes.com.br/midia/revista\#page/2> Acesso em junho de 2014. 


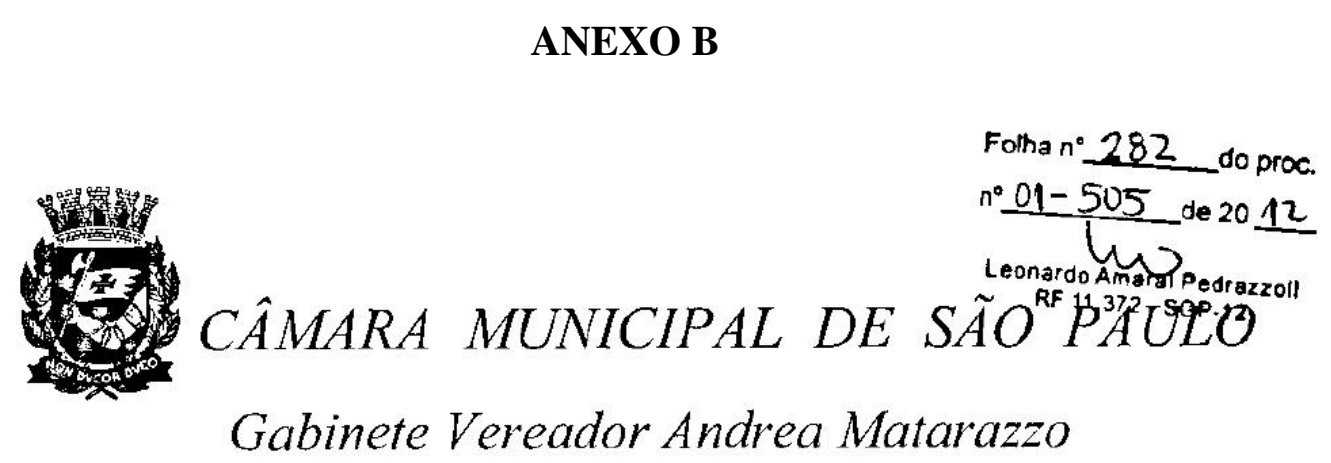

TID: 107.89255

São Paulo, 10 de junho de 2013.

Memo. 055/2013.

$1^{\circ} \mathrm{GV}$ - Gabinete Vereador Andrea Matarazzo

- $A$

Secretaria da Comissão de Política Urbana Metropolitana e Meio Ambiente

Prezados Senhores.

Solicitamos a juntada no processo do PL 505/2012 - Operação Urbana Consorciada Água Branca, material anexo recebido como contribuiçăo durante a Reunião Técnica Devolutiva do dia 06/06/2013.

-

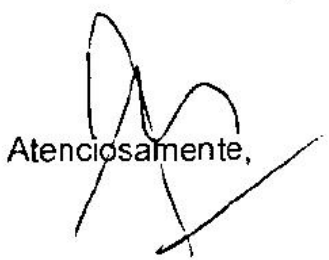

Andrea Matarazzo

Vereador - PSDB 
De audiência para reunião técnica

$$
\begin{aligned}
& \text { Folha } n^{\circ} 283 \text { do proc. } \\
& n^{\circ} 01-505 \text { de } 20 \text { 12 } \\
& \begin{array}{c}
\text { Leonardo Amâr Pedrazzoll } \\
\text { RF } 11.372-\text { SGP }-12
\end{array}
\end{aligned}
$$

Abaixo assinado:

Movimento Moradores da Água Branca

Conseg Perdizes Pacaembu

Movimento SOS parque da Água Branca

Preserva Vila Pompéia

Ofícios:

Consabs Perdizes Água Branca

Amigos de Vila Pompéia

Viva Pacaembu por São Paulo

Defenda São Paulo

- Prazo do requerimento do vereador Paulo Frange.

- Informações de Finanças que não foram dadas na audiência

Publica. De 22/5 /2013

? Cepac ( titulo mobiliário regido por lei federal) dois valores (são propostos valores diferentes para resguardar a viabilidade econômica de empreendimentos residenciais, sobretudo a tipologia incentivada, num eventual cenário de alta de empreendimentos comerciais que elevem os preços dos produtos imobiliários, preços de terrenos e de CEPAC) 
Fotha $n^{\circ} 284$ do proc.

$n^{\circ} 01-505$ de 2012

Onde será gasto o dinheiro arrecadado (no programa de intervenções vinculado aos objetivos do PL 505, como consta do Art. $8^{\circ}$ da proposta)

Serão separados os recursos arrecadados dos recursos em discussão? (Pode-se reformular o texto do artigo 70: os recursos arrecadados na vigência da lei 11.774 / 95 e não utilizados deverão ser aplicados de acordo com a seguinte ordem de prioridade :

A) realização de projetos e obras de drenagem nas áreas de abrangência das bacias dos córregos existentes no perimetro da operação urbana

B) Realização de projetos e obras de expansão do sistema viário dos setores localizados ao Sul das ferrovias;

C) Realização de projetos e obras de construção ou requalificação de habitações de interesse social no perimetro da operação urbana;

D) Realização de estudos e serviços constantes da Licença Ambiental Prévia;

E) Catalogação de imóveis de possivel interesse histórico, cultural e arquitetônico no perimetro da operação urbana;

F) Remuneração da SP Urbanismo e SP Obras;

- Retorno sobre devolutiva solicitada na audiência do dia 16/5/2013. 
Folha $n^{\circ} 285$ do proc.

$n^{\circ} 01-50.5$ de 2012

- Oficio encaminhado solicitando técnicos para devolutiveproempmaral Pedrazzoll resposta (não há registro de entrada do citado oficio na SMDU ou na SP Urbanismo)

- Duvidas da sociedade civil: priorização $x$ recursos

Garantias de HIS ( o mais importante é reservar terrenos. Pode-se definir uma quantidade mínima de HIS a ser construida no perímetro - os terrenos reservados possibilitam a construção de 1500 a 2000 unidades dentro do perimetro - e quantidade mínima de atendimento no perímetro expandido). Ao todo, se forem construídas ou requalificadas no mínimo 4.000 unidades estará atendida cerca $1 / 3$ da demanda por reassentamentos de domícilios em favelas nas subprefeituras da Lapa, Casa Verde, Santana e Freguesia do 0.)

Garantias de Drenagem (única proposta que deve sair do perímetro) ideal seria aumentar a permeabilidade por meio de retenção (há estudos prontos que propõem o aumento da retenção no interior dos lotes em cerca de 05 vezes se comparado à lei das piscininhas)

Garantias do parque previsto, como fica a sessão de área dos clubes Palmeiras e São Paulo ( PL prorrogando período) Cabe à Câmara aceitar ou rejeitar a prorrogação das concessões. Caso seja rejeitada a prorrogação haverá mais área para parques, equipamentos públicos e HIS; 
Folthan 286 _o proc.

$n^{0} \underline{01} \cdot 505$ de 2012

Leonardo An $_{\text {mat }} \beta_{\text {edrazzolf }}$

Levantamento histórico - inventário do patrimônio cultural,

$R F$ 11.372 - SGP-12

arqueológico, fabril e arquitetônico

Áreas Contaminadas

O EIA-RIMA contém o mapeamento das áreas contaminadas e suspeitas de contaminação. O controle sobre a ocupação de áreas contaminadas os suspeitas está expresso no Art. 13 - parágrafo $7^{\circ}$ do PL.

Equipamentos Públicos - quantificar e projetar demanda

O estudo realizado pela Walm indicou como referência a construção de 17 equipamentos de educação (sendo 10 creches, 03 EMEI, 04 EMEF e uma escola de nível médio com $41.000 \mathrm{~m}^{2}$ de terreno e $29.000 \mathrm{~m}^{2}$ de área construida), 03 equipamentos de saúde (sendo 02 UBS e 01 UBS com AMA acoplada com $2.500 \mathrm{~m}^{2}$ de terreno e $2.500 \mathrm{~m}^{2}$ de área construída). Quanto a áreas de lazer, esporte foi indicada a necessidade de, no mínimo $264.000 \mathrm{~m}^{2}$ de terreno, sendo que o plano de melhoramentos públicos reserva 0 equivalente a $320.000 \mathrm{~m}^{2}$ de novas áreas verdes. Com relação à segurança, o estudo informa que a polícia militar e a guarda civil atuam por demandas efetivas. A área de terreno para uma delegacia consome cerca de $1000 \mathrm{~m}^{2}$ de terreno e $500 \mathrm{~m}^{2}$ de área construída.

O total de áreas reservadas para equipamentos institucionais no plano de melhormanetos públicos é da ordem de $50.000 \mathrm{~m}^{2}$. Superior, portanto às demandas inicialmente dimensionadas. 


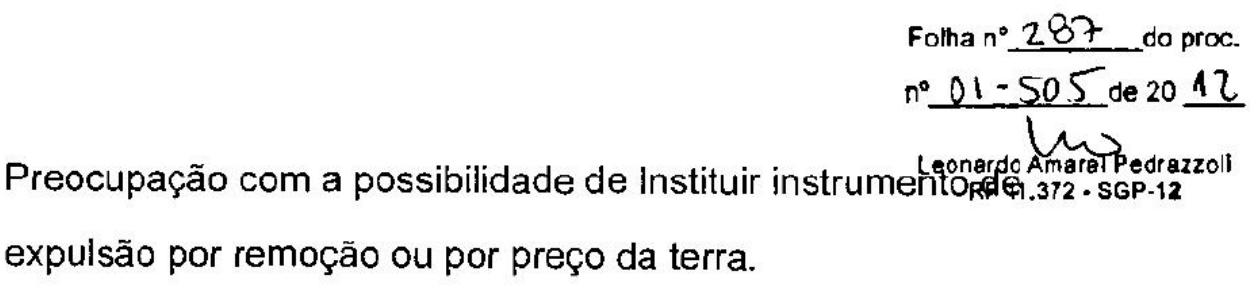

Há terrenos reservados para HIS e a viculação de estoque da tipologia incentivada para contornar essa questão.

Preocupação com possibilidades de concessão urbanística para a gleba Pompéia

Não está sendo proposta a concessão urbanística e sim o reloteamento da gleba com a finalidade de se obter áreas de sistema viários, verdes, institucionais e para HIS. O que se prevê é a constituição d eum fundo de investimento imobiliário para a relaização do reloteamento e implantação de infraestruturas. $A$ concessão urbanística depende da aprovação de lei especifica. Adensamento populacional $x$ equipamentos e transporte $x$ impacto cumulativo e de incomodidades

Empreendimentos geradores de impacto de vizinhança devem elaborar EIV-RIVI e ter suas licenças obtidas junto ao CADES que estabelece as mediadas mitigadoras necessárias. Recursos da operação urbana não devem ser utilizados para mitigar impactos de empreendimentos particulares.

Controlar impermeabilização do solo

É proposta taxa de permeabilidade de $30 \%$.

Estudos ambientais especificos para o conjunto das obras 


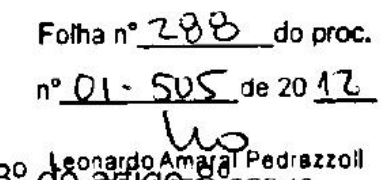

É exigência da LAP e consta do PL 505 - parágrafo $3^{\circ}$ d8onardo 4 amg

Grupo de Gestão - Controle de Usos e de protocolo antes da aprovação.

É proposto no PL que os empreendimentos protocolados até a data de expedição da Licença Ambiental Prévia (11 de abril de 2012) serão avaliados segundo os parâmetros da lei atual. Os protocolados depois da data de emissão da LAP e até a aprovação da nova lei que não tenham sido apreciados pela CTLU estarão sujeitos às disposições da nova lei.

São atribuições do Grupo de Gestão: deliberar sobre o plano de prioridades e respectivos recursos. Cabe ainda ao grupo de gestão o monitoramento do desenvolvimento da operação urbana, conforme artigo 59 do $\mathrm{PL}$, com base na sistemática de indicadores cuja elaboração está prevista no parágrafo único, inciso $\mathrm{V}$ do art. 54 do PL.

Discussões controversas OUAC x Plano Diretor x Plano Regional $x$ Plano de Bairro

Trata-se de escalas diferentes e processos que se retroalimentam. Os princípios do PL 505 são princípios básicos do PDE.

Licenças Ambientais $\mathrm{x}$ atribuição do empreendedor e o órgão licenciador

O empreendedor da operação urbana é a Prefeitura do Município de São Paulo. 